\title{
Integrated Solid Waste Management of Sevierville, Tennessee
}

National Renewable Energy Laboratory

1617 Cole Boulevard

Golden, Colorado 80401

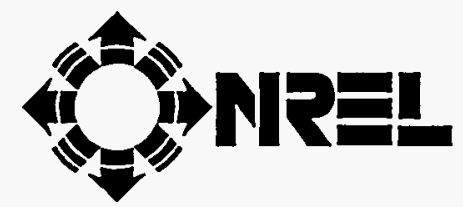

National Renewable Energy Laboratory 1617 Cole Boulevard Golden, Colorado 80401-3393

A national laboratory of the U.S. Department of Energy Managed by the Midwest Research Institute for the U.S. Department of Energy Under Contract No. DE-AC36-83CH10093 



\section{Integrated Solid Waste Management of Sevierville, Tennessee}

National Renewable Energy Laboratory 1617 Cole Boulevard Golden, CO 80401

NREL technical monitor: Philip Shepherd

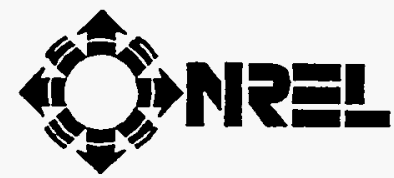

National Renewable Energy Laboratory 1617 Cole Boulevard Golden, Colorado 80401-3393 A national laboratory of the U.S. Department of Energy Managed by the Midwest Research Institute for the U.S. Department of Energy Under Contract No. DE-AC36-83CH10093

Prepared under Subcontract No. AAL-3-13185-01

November 1995 


\section{NOTICE}

This report was prepared as an account of work sponsored by an agency of the United States government. Neither the United States government nor any agency thereof, nor any of their employees, makes any warranty, express or implied, or assumes any legal liability or responsibility for the accuracy, completeness, or usefulness of any information, apparatus, product, or process disclosed, or represents that its use would not infringe privately owned rights. Reference herein to any specific commercial product, process, or service by trade name, trademark, manufacturer, or otherwise does not necessarily constitute or imply its endorsement, recommendation, or favoring by the United States government or any agency thereof. The views and opinions of authors expressed herein do not necessarily state or reflect those of the United States government or any agency thereof.

Available to DOE and DOE contractors from:

Office of Scientific and Technical Information (OSTI)

P.O. Box 62

Oak Ridge, TN 37831

Prices available by calling (615) 576-8401

Available to the public from:

National Technical Information Service (NTIS)

U.S. Department of Commerce

5285 Port Royal Road

Springtield, VA 22161

(703) $487-4650$

Printed on paper contäining at least $50 \%$ wastepaper, including $10 \%$ postconsumer waste 


\title{
Abstract
}

The subject document reports the results of an in-depth investigation of the fiscal year 1992 cost of the City of Sevierville, Tennessee integrated municipal solid waste management (IMSWM) system, the energy consumed to operate the system, and the environmental performance requirements for each of the system 's waste-processing and disposal facilities.

Actual data from records kept by participants is reported in this document. Every effort was made to minimize the use of assumptions, and no attempt is made to interpret the data reported. Analytical approaches are documented so that interested analysts may perform manipulation or further analysis of the data. As such, the report is a reference document for MSW management professionals who are interested in the actual costs and energy consumption for a one-year period, of an operating IMSWM systems.

The report is organized into two main parts. The first part represents the Executive Summary and Case Study portion of the report. The Executive Summary provides a basic description of the study area and selected economic and energy information. Within the Case Study are detailed descriptions of each component operating during the study period; the quantities of solid waste collected, processed and marketed within the study boundaries, the cost of managing municipal solid waste in Sevierville; an energy usage analysis; and finally a review of federal, state and local environmental requirement compliance; a reference section and a glossary of terms.

The second part of the report focuses on a more detailed discourse on the above topics.

In addition, the methodology used to determine the economic costs and energy consumption of the system components is found in the second portion of this report. The methodology created for this project will be helpful for those professionals who wish to break out the costs of their own integrated systems.

Other reports in the series include a Synopsis of Results and Methodologies which presents the principal findings from the case studies and case studies of the each of the six IMSWM systems evaluated in this program. In addition to the City of Sevierville, Tennessee, the following systems participated in the evaluation: Minneapolis/Hennepin County, Minnesota; Palm Beach County, Florida; Scottsdale, Arizona; Seattle, Washington; and Springfield, Massachusetts.

Case Study

\section{Key Words}

\author{
Co-Composting \\ Cost Analysis \\ Energy Analysis \\ Energy Recovery \\ Environmental Requirements: solid waste management \\ Integrated Municipal Solid Waste Management \\ Landfilling \\ Materials Recovery \\ Mixed Municipal Solid Waste Composting \\ Municipal Solid Waste \\ Recycling \\ Resource Recovery \\ Sevierville, Tennessee \\ Solid Waste \\ SWANA
}




\section{Foreword}

This case study report is one of six developed for the following integrated municipal solid waste management systems:

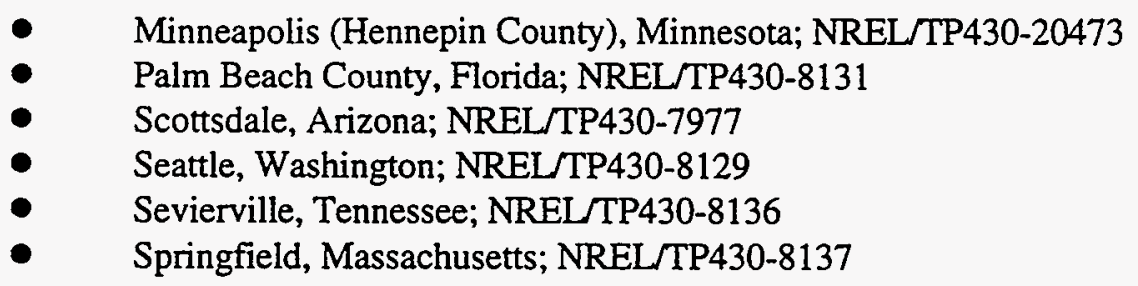

All the reports, including a summary report (NREL/TP430-20471), are available through the National Renewable Energy Laboratory, 1617 Cole Boulevard, Golden, Colorado, 80401, or call (303)275-4363.

The authors are extremely grateful for the support and cooperation of the six systems managers and participants in those six systems. Without their assistance, this effort would not have been possible.

Funding for the conduct of the case studies and the development of the six reports was provided by the American Plastics Council and the United States Department of Energy's National Renewable Energy Laboratory.

In conducting the studies, the authors experienced considerable difficulty in gathering economic and energy information. In municipal solid waste management, no standard accounting methods exist. Further, local governments by tradition and practice maintain their financial records in a variety of ways to serve their own specific needs. The lack of a standard accounting procedure in the United States, and of standard definitions of solid waste, made the collection and analysis of the economic data a challenge. The methods for developing the cost information for this effort will be helpful to those with responsibilities for planning and implementing integrated municipal solid waste management systems. Also, the six sets of cost data will be useful for guiding other systems managers in their planning, cost accounting, and measuring of performance.

The development of the energy information represents a major step forward in analyzing integrated municipal solid waste management systems. The information in the six studies and the analytical methodology will be extremely useful to integrated municipal solid waste management systems planners, decision makers, and managers in the future.

Finally, as might be expected, the environmental regulatory information is limited. Although landfill and combustion facilities are under well-defined regulations, other portions of integrated municipal solid waste systems are not. The end result of these limitations is that the information presented on conformance with environmental requirements is sketchy for systems that do not include combustion.

A final caution to the readers of these reports is to not attempt to try to compare one system against the other. The authors deliberately did not do so for the very sound reason that it is ill-advised to attempt to compare systems that:

- are geographically different,

- are politically different,

- are structurally different in providing municipal solid waste services, 


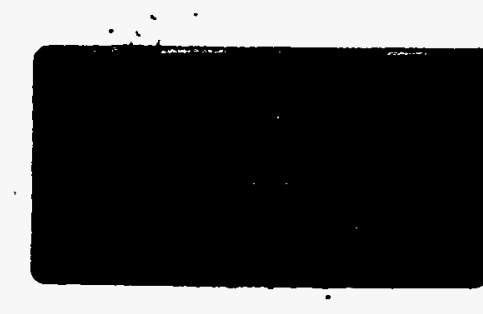

5
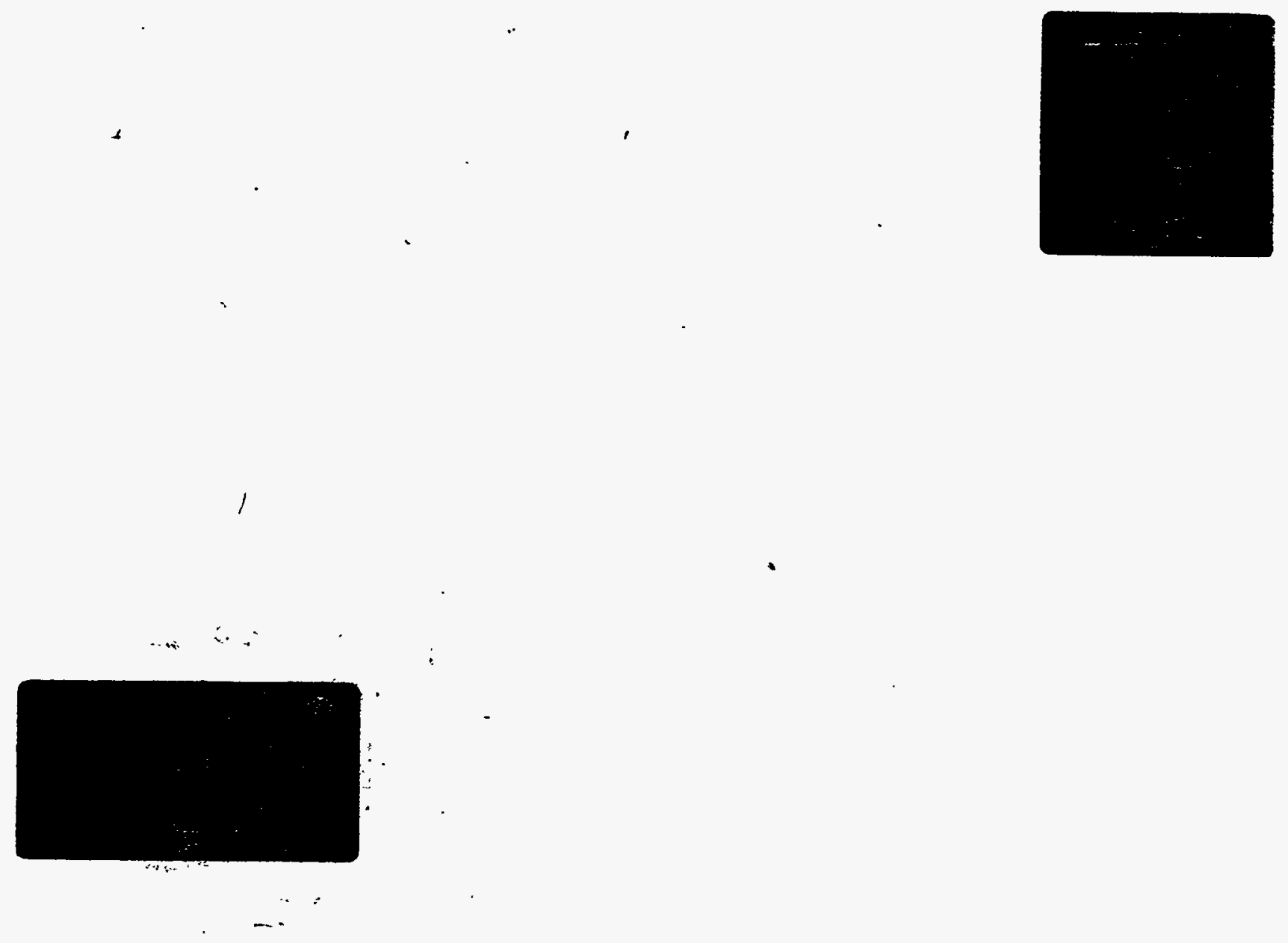


\section{Acknowledgments}

The authors are especially grateful for the assistance and support of many individuals and organizations who contributed information for this Sevierville Case Study. From the city of Sevierville: Bob Robbins and Jim Deanda. From Sevier Solid Waste, Inc.: Pamela Williams and John deMoll. From Hickman and Company, P.C.: Ms. Lila Teaster and Ms. Jennifer B. Finchum. From Flynt Engineering: Ms. Kathryn Rutherford. And from Bedminster Bioconversion: Ken Aiani, Dan Carter, Jeff Thomas, Terry J. Williams, and Brian Bailey. 


\section{Contents}

\section{Condensed Sevierville Case Study}

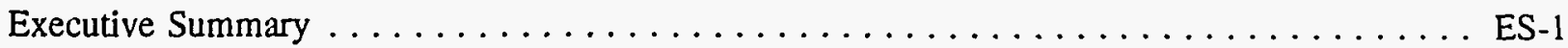

Introduction to Condensed Report $\ldots \ldots \ldots \ldots \ldots \ldots \ldots \ldots \ldots \ldots \ldots \ldots \ldots \ldots$

Sevier County's Integrated Municipal Solid Waste Management System $\ldots \ldots \ldots \ldots \ldots \ldots$

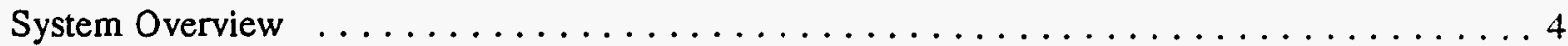

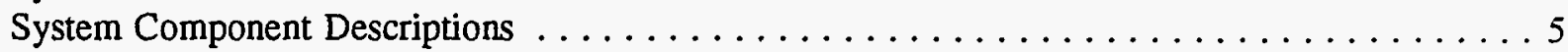

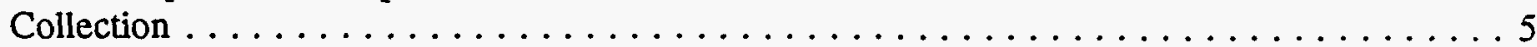

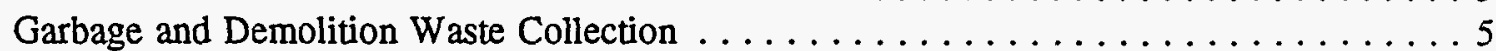

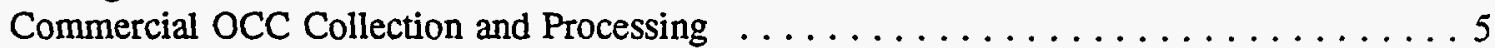

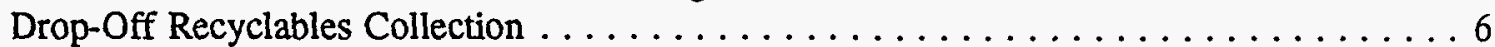

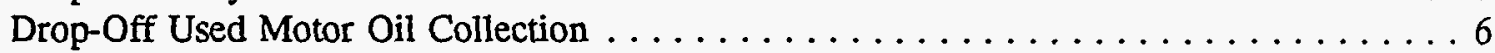

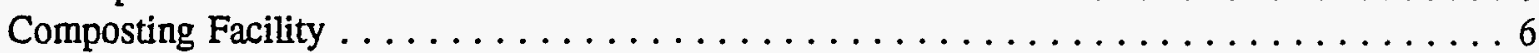

Class I Landfills $\ldots \ldots \ldots \ldots \ldots \ldots \ldots \ldots \ldots \ldots \ldots \ldots \ldots \ldots \ldots \ldots$

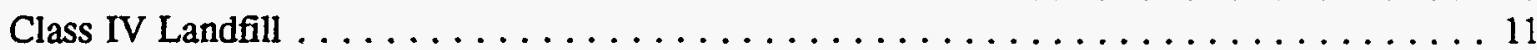

Public Information and Education Programs $\ldots \ldots \ldots \ldots \ldots \ldots \ldots \ldots \ldots \ldots \ldots$

MSW Collected, Processed, and/or Disposed of in Sevierville $\ldots \ldots \ldots \ldots \ldots \ldots \ldots$

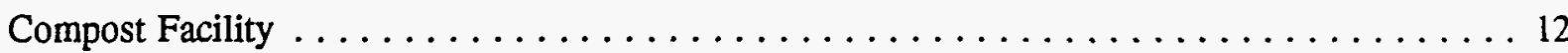

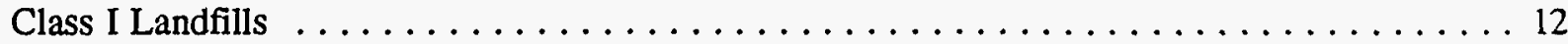

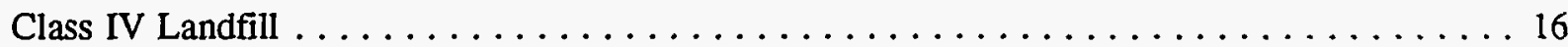

Recyclables Drop-Off and Commercial Corrugated Programs $\ldots \ldots \ldots \ldots \ldots \ldots \ldots$

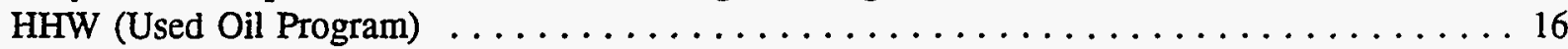

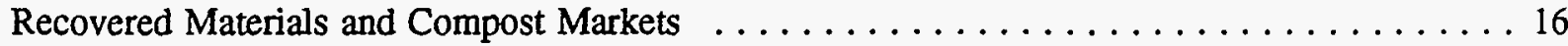

Cost of MSW Management in the City of Sevierville $\ldots \ldots \ldots \ldots \ldots \ldots \ldots \ldots$

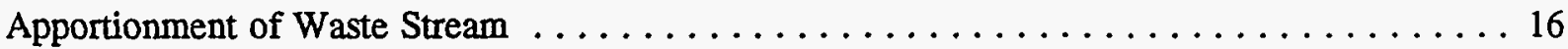

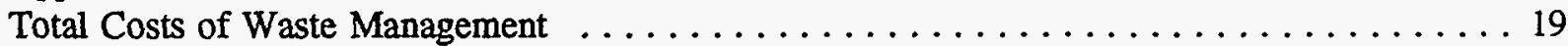

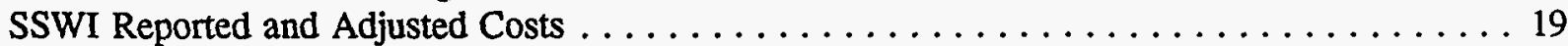

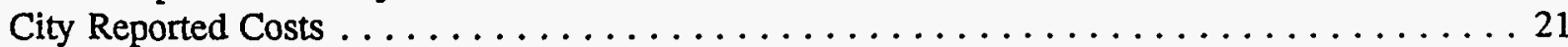

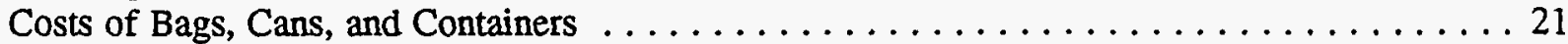

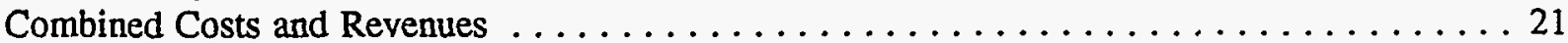

Total Costs of Analyzed MSW Management and Costs by

Functional Area . . . . . . . . . . . . . . . . . . . . . . . . . . 22

Allocation of Analyzed MSW Management Costs by Type of Waste $\ldots \ldots \ldots \ldots \ldots \ldots 25$

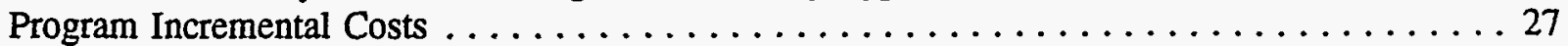

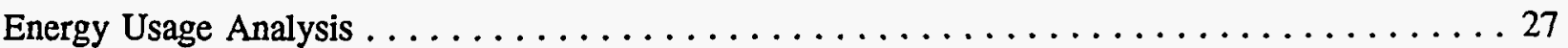

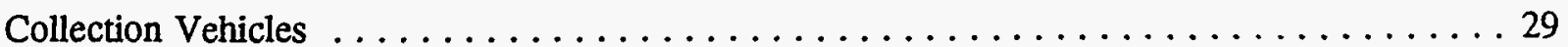

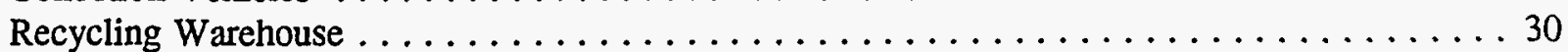




\section{Contents (Continued)}

$\underline{\text { Page }}$

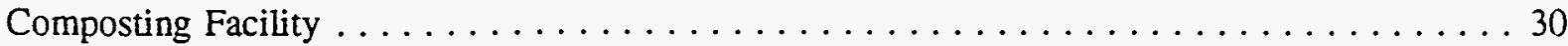

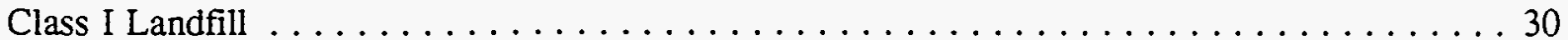

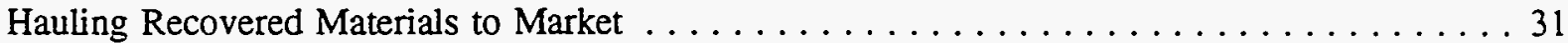

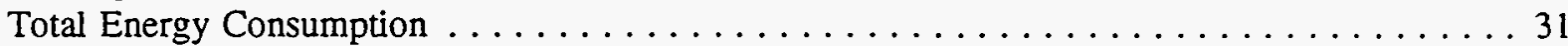

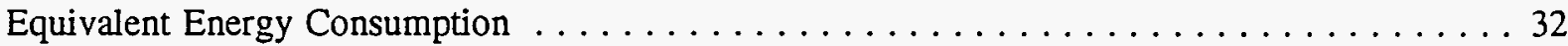

Environmental Regulations and Permitting Requirements $\ldots \ldots \ldots \ldots \ldots \ldots \ldots$

Overview of Relevant Federal Environmental Legislation

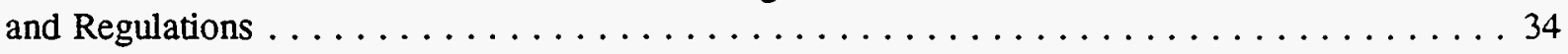

Overview of State and Local Environmental Regulations $\ldots \ldots \ldots \ldots \ldots \ldots \ldots$

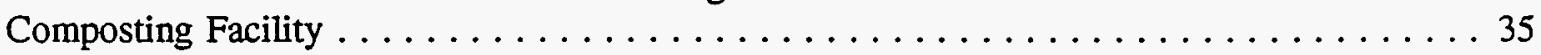

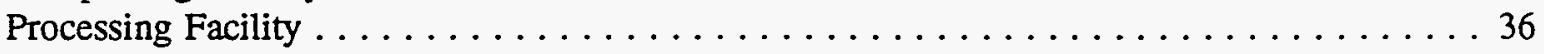

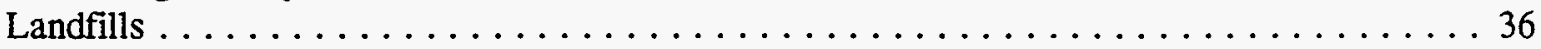

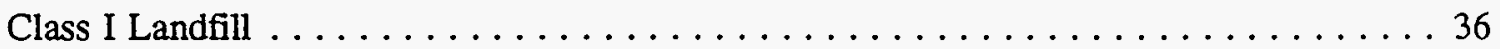

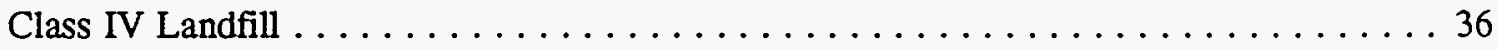

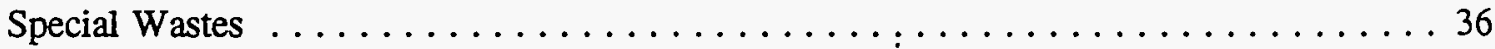

Overview of Occupational Safety and Health Regulations $\ldots \ldots \ldots \ldots \ldots \ldots \ldots \ldots \ldots$

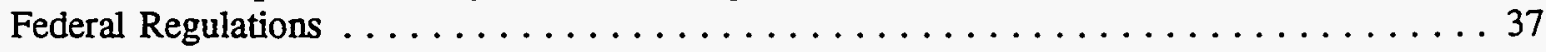

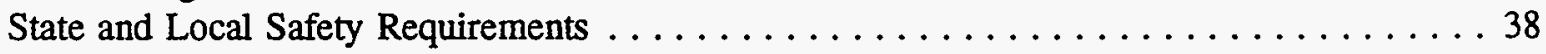

Appendix A: References

Appendix B: Glossary of Terms 


\section{List of Figures}

Page

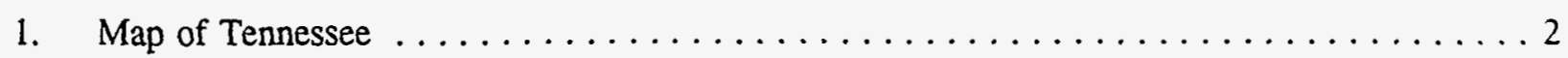

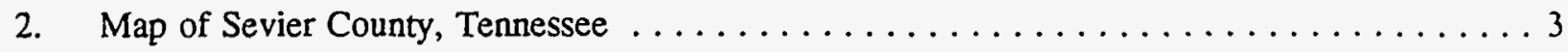

3. Sevier Solid Waste New Class I Landfill Site Plan $\ldots \ldots \ldots \ldots \ldots \ldots \ldots \ldots$

4. Sevier Solid Waste Composting Facility Material Flow Diagram $\ldots \ldots \ldots \ldots \ldots \ldots \ldots$

5. Sevier Solid Waste Composting Facility Floor Plan $\ldots \ldots \ldots \ldots \ldots \ldots \ldots \ldots \ldots$

6. Sevier County Waste Flow and Resource Recovery Diagram $\ldots \ldots \ldots \ldots \ldots \ldots \ldots$

7. City of Sevierville Waste Flow and Resource Recovery Diagram $\ldots \ldots \ldots \ldots \ldots \ldots$ 


\section{List of Tables}

$\underline{\text { Page }}$

1. 1990 Population in Sevier County $\ldots \ldots \ldots \ldots \ldots \ldots \ldots \ldots \ldots \ldots \ldots \ldots \ldots \ldots$

2. Comparison of Total County and Sevierville Waste Quantities

(FY 1993/1994) . . . . . . . . . . . . . . . . . . . . . . . . . . . . . . 13

3. Markets for Recovered Materials and Compost in FY $1993 / 1994 \ldots \ldots \ldots \ldots \ldots \ldots \ldots$. . . . . . 17

4. City of Sevierville FY 1993/1994 Total Waste and Analyzed

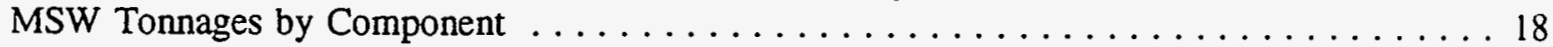

5. SSWI Revenues and Expenses, Year Ending June 30, $1994 \ldots \ldots \ldots \ldots \ldots \ldots$

6. Total Gross Sevierville Cost of Collection (FY 1993/1994 \$) . . . . . . . . . . . . . 21

7 Total Gross and Net Costs of IMSWM System (FY 1993/1994 \$) . . . . . . . . . . . . 21

8. Total Gross Costs of Sevierville's IMSWM System Allocated by

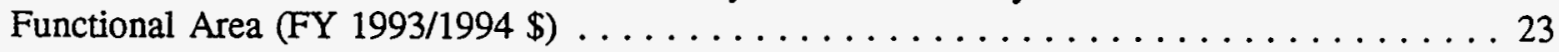

9. Total Revenues of Sevierville's IMSWM System Allocated by Functional

Area (FY 1993/1994\$) . . . . . . . . . . . . . . . . . . . . . . . . 24

10. Gross Costs of Managing Analyzed MSW by Functional Area

(FY 1993/1994 \$)

11. Net Costs of Managing Analyzed MSW by Functional Area

(FY 1993/1994 \$)

12. Total Gross Costs of Sevierville's IMSWM System Allocated by

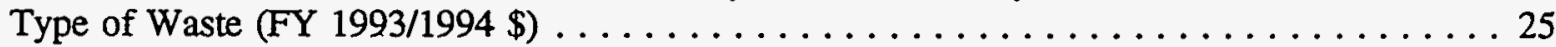

13. Total Net Costs of Sevierville's City IMSWM System Allocated by

Type of Waste (FY 1993/1994\$) . . . . . . . . . . . . . . . . . . . . . . 26

14. Incremental Cost of OCC Recovery Program (FY 1993/1994) . . . . . . . . . . . . . 28

15. Incremental Cost of the Composting Facility (FY 1993/1994) . . . . . . . . . . . 28

16. Sevierville Garbage Collection Vehicles . . . . . . . . . . . . . . . . . . . . 29

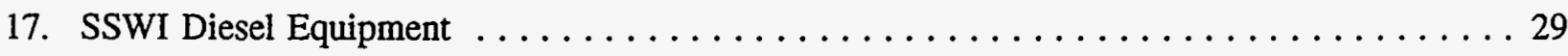

18. Energy Consumed to Collect Analyzed MSW in Sevierville (FY 1993/1994) . . . . . . . . . . . . . . . . . . . . . . . 30

19. Mobile Equipment Used at Composting Facility . . . . . . . . . . . . . . . 30 


\section{List of Tables (Continued)}

$\underline{\text { Page }}$

20. Total Energy Consumption for Managing Analyzed MSW (FY 1993/1994) . . . . . . . . . . . . . . . . . . . . . . . . . . . . . 32

21. Equivalent Per Gallon Energy Consumption for Managing Analyzed MSW (FY 1993/1994 Equivalent Diesel Gallons Per Ton) 


\section{Executive Summary}

This executive summary provides a review of the key findings of the Sevierville case study. Readers are advised to read the condensed Sevierville case study to fully understand how the economic, energy, and environmental results were developed. In addition, all data collected and analyzed during this study are available in the in-depth Sevierville case study, with Appendices A through D.

Each integrated municipal solid waste management (IMSWM) system is unique due to geography, climate, customs, politics, and time. However, readers may benefit from the findings of this study and the study techniques and methodology to develop actual economic, energy, and environmental facts about their own IMSWM systems. Because each system is unique, readers are cautioned not to compare the findings of this particular study with their own systems.

\section{Background}

Sevierville, Tennessee, is located in Sevier County and is the county seat. Sevier County is located in the southeast portion of the state about 25 miles from Knoxville. The population of Sevier County in 1990 was approximately 51,043 . Sevierville is the largest city in the county with a 1994 estimated population of 7500. In 1990, there were approximately 3321 housing units. Tourism is an important part of Sevierville's economy, but Sevierville also boasts an industrial park with almost 20 industries and another industrial park scheduled to open soon. Gatlinburg and Pigeon Forge are two other cities in Sevier County that are home to several tourist attractions.

During fiscal year (FY) 1993/1994, about 66,710 tons of municipal solid waste (MSW) were generated in Sevier County. Approximately 13,750 tons, or $21 \%$ by weight, are estimated to have been generated in Sevierville. These quantities include MSW, as well as demolition waste, sewage sludge, and grease. The relatively high generation rate in Sevierville is probably due to the large amount of commercial waste generated by tourism. In 1988, Sevier Solid Waste, Inc. (SSWI), a not-for-profit corporation, was formed as an intergovernmental venture between the county and the cities of Sevierville, Gatlinburg, and Pigeon Forge to address waste management in the county. SSWI owns the MSW management facilities currently serving the entire county.

\section{Sevier Solid Waste, Inc.}

Sevier Solid Waste, Inc., was established in 1988. The primary purposes set forth in its charter are to:

(1) Receive and administer funds to acquire, construct, equip, and maintain a solid waste landfill and related facilities for the county

(2) Arrange for the disposal of solid waste through appropriate disposal methods or to contract with others for the hauling or disposal of such solid waste.

The charter provides SSWI with powers, privileges, rights, and immunities necessary or convenient for carrying out the purposes for which it was formed. These include the power to contract indebtedness, including bonds, and enter into contracts and leases with other entities.

SSWI is managed by a board of directors made up of one member from each of the three municipalities listed above and the county. Each director's vote carries the weight of the director's proportionate interest determined by the municipality's respective landfill tonnages at the time the Interlocal Agreement was 
signed. Respective quantities of waste managed in the SSWI facilities are also used to determine the relative amount paid by each local government for use of the SSWI facilities.

\section{System Overview}

The county's FY 1993/1994 IMSWM system consisted of the following integrated system components:

- Collection of residential and commercial garbage and demolition wastes by the cities and the county (Sevierville's Sanitation Department collects garbage Monday through Friday from all residential dwellings on a once-per-week basis, and from commercial businesses and institutions on varying schedules)

- Collection of old corrugated containers (OCC) from businesses by SSWI and processing in a recycling warehouse owned and operated by SSWI

- Drop-off collection and recycling of aluminum, plastic, and newspapers by a private hauler under contract with SSWI

- Drop-off collection and recycling of used motor oil by a private hauler

- A mixed waste composting (150 tons per day [TPD] MSW/75 TPD sewage sludge) facility-with ferrous metals recovery capabilities-owned by SSWI and operated for SSWI by a private contractor, Bedminster Bioconversion Corporation (the facility began operations in September 1992 under a 5-year - contract with Bedminster)

- A new Class I landfill and extension to an old landfill owned and operated by SSWI for the disposal of residue from the compost facility and bypass garbage

- A Class IV landfill with ferrous metals, wood, and tire recovery capabilities owned and operated by SSWI for the recycling and disposal of construction and demolition debris, tires, and other bulky wastes.

\section{Definitions}

Solid waste is defined in this case study to include MSW, as well as demolition waste, sewage sludge, and grease, all of which are managed by SSWI. MSW includes garbage from residential and commercial sources, recyclables, bulky waste and household hazardous waste (HHW).

ANALYZED MSW-That portion of the total MSW stream for which the associated management net costs are known, or at a minimum, can be reasonably estimated. The reason for limiting the types of MSW included in analyzed MSW is that only that portion of MSW should be included for which sufficient data were available to draw defensible conclusions regarding the allocation of cost to the tons of MSW managed. Consequently, the types of MSW included in analyzed MSW will vary between IMSWM systems.

GARBAGE-Garbage is all MSW exclusive of source-separated trash, recyclables, yard waste, household hazardous waste, and bulky waste.

DEMOLITION WASTE-Materials resulting from the construction, remodeling, repair or demolition of buildings, bridges, pavements, and other structures, as well as bulky waste, wood waste, brush, and tires. 
PROGRAM INCREMENTAL COSTS (OR SAVINGS)-Determined for MSW management components (or programs) of each IMSWM system by calculating the system cost of MSW management, first with the inclusion of a specific program, and then calculating the cost of MSW management without that program. Landfilling is considered the basic program that is not optional. Therefore, the Program Incremental Cost is the difference between the cost of managing MSW with the inclusion of a particular program and the cost of managing MSW without that program.

RECYCLABLES-Materials that still have useful physical or chemical properties after serving their usefulness for a given individual or firm, and can, therefore, be reused or recycled for the same or other purposes.

\section{Key Findings}

\section{Discussion of Costs}

Of the approximately 13,750 tons of solid waste managed within the city, about 10,300 tons were analyzed ("analyzed MSW") to determine the cost of Sevierville's IMSWM system. Because the collection costs for the approximately 31 tons of drop-off recyclables are not known, this tonnage is excluded from the analysis, as is the tonnage of demolition waste and sludge/grease (which is not considered MSW). The cost of MSW management in Sevierville as reported in the study includes costs for garbage containers (plastic bags, trash can, and other containers purchased by residents and businesses, collection, processing, disposal, and the marketing of recovered materials for the 10,300 tons. According to information from Bedminster, finished compost from the system goes to some form of beneficial use. Much of the material is given away in an effort to develop markets for the material. Uses include agricultural research, landscaping, athletic fields, and parks. The price for the material that is sold is approximately $\$ 10.00$ per ton. However, as markets are currently being established, the majority of the material is being given away, and revenue from the sale of compost is negligible.

\section{Overall Program Costs}

The total FY 1993/1994 cost to manage the approximately 10,300 tons of analyzed MSW was about $\$ 1.092$ million, or about $\$ 106$ per ton. This total cost breaks down to, in rounded numbers:

Table ES-1. Cost of Program Elements

\begin{tabular}{||l|c|c||c||}
\hline \multicolumn{1}{|c|}{ Category } & Tonnage & Total Cost & $\begin{array}{c}\text { Total Cost Per } \\
\text { Ton }\end{array}$ \\
\hline Garbage/composting & 10,280 & $\$ 1.076$ million & $\$ 105$ \\
\hline Corrugated & 31 & $\$ 16,560$ million & $\$ 534$ \\
\hline TotaVAverage & 10,311 & $\$ 1.092$ million & $\$ 106$ \\
\hline
\end{tabular}

Collection costs account for $38 \%$ ( $\$ 40$ per ton) of the total cost of the Sevierville system, and the composting facility accounts for $32 \%$ ( $\$ 34$ per ton) of the cost. The Class I landfill accounts for $19 \%$ ( $\$ 21$ per ton) of the total cost, the commercial OCC collection and processing accounts for $1 \%$ ( $\$ 500$ per ton), and the general and administrative ( $\mathrm{G} \& \mathrm{~A}$ ) expense is $9 \%$ ( $\$ 10$ per ton). 


\section{Program Incremental Costs}

The incremental cost for each of the resource recovery programs, i.e., the cost (or savings) associated with adding the resource recovery program to the IMSWM system, is the difference between the cost of managing all the MSW with the inclusion of a particular program and the cost of managing all the MSW with the inclusion of a particular program and the cost of managing all the MSW without that program. The program incremental cost (or savings) is, therefore, a measure of the impact of any particular program on the cost of managing all MSW.

The FY 1993/1994 program incremental cost (or savings) of each of the resource recovery programs was, in rounded numbers:

Table ES-2. Incremental Cost of Program Elements

\begin{tabular}{||l|c|cc||}
\hline \multirow{2}{*}{ Program } & \multirow{2}{*}{ Tonnage } & \multicolumn{2}{|c|}{$\begin{array}{c}\text { Incremental Cost } \\
\text { (Savings) }\end{array}$} \\
\cline { 3 - 4 } & & Dollars & \$ Per Ton \\
\hline Composting & 10,280 & $\$ 211,680$ & $\$ 21$ \\
\hline Corrugated & 31 & $\$ 14,741$ & $\$ 476$ \\
\hline
\end{tabular}

In addition to the incremental cost or savings that can be attributed to each of the resource recovery programs, each of them contributes materials to the economy and reduces the use of available landfill space.

\section{Energy Usage Analysis}

The primary forms of energy used within Sevierville's IMSWM system are transportation fuels for collection, haul to market, and facility vehicles, and electricity consumed internally by solid waste processing or disposal facilities. Energy consumed in the use of recovered materials to make new products is excluded because it is beyond the IMSWM systems boundary. Data on energy consumption for the Sevierville IMSWM system were analyzed, yielding estimates for the equivalent diesel gallons per ton shown in the table below. 
Table ES-3. Equivalent Per Gallon Energy Consumption for Managing Analyzed MSW (FY 1993/1994) (equivalent diesel gallons/ton) ${ }^{(1)}$

\begin{tabular}{|c|c|c|c|}
\hline \multirow[b]{2}{*}{ Activity } & \multicolumn{3}{|c|}{ Equivalent Diesel Gallons per Ton } \\
\hline & Garbage & $\begin{array}{l}\text { Commercial } \\
\text { Corrugated }\end{array}$ & $\begin{array}{c}\text { Total Analyzed } \\
\text { MSW }\end{array}$ \\
\hline \multicolumn{4}{|l|}{ Collection Vehicles } \\
\hline Garbage & 1.75 & NA & 1.75 \\
\hline Corrugated & NA & 7.38 & 0.02 \\
\hline Subtotal & 1.75 & 7.38 & 1.77 \\
\hline \multicolumn{4}{|l|}{ Facilities } \\
\hline Recycling Warehouse & NA & 4.41 & 0.01 \\
\hline Composting Facility & 2.53 & NA & 2.52 \\
\hline Class I Landfill & 0.17 & NA & 0.17 \\
\hline Subtotal & 2.70 & 4.41 & 2.70 \\
\hline \multicolumn{4}{|l|}{ Haul to Markets (2) } \\
\hline Compost & 0.08 & NA & 0.08 \\
\hline Corrugated & NA & 2.20 & 0.01 \\
\hline Ferrous Metals & 0.02 & NA & 0.02 \\
\hline Subtotal & 0.10 & 2.20 & 0.11 \\
\hline TOTAL & 4.55 & 13.99 & 4.58 \\
\hline
\end{tabular}

Notes:

${ }^{1}$ Based on assumptions used in other case studies, energy content of diesel fuel assumed to be 146,390 Btus/gallon. Quantity of garbage in analyzed MSW is 10,280 tons. Quantity of commercial old comugated containers (OCC) in analyzed MSW is 31 tons.

${ }^{2}$ Includes energy consumed to haul materials to first destination after leaving Sevier Solid Waste, Inc. site. For compost and OCC, the first destination is the end-user/remanufacturer. This destination for ferrous metals is an intermediate processor. Data on energy consumption at the intermediate processing facility and energy consumed while hauling the ferrous metals to a remanufacturer were not available.

\section{Environmental Regulatory Framework}

Environmental regulations for the elements of an IMSWM system are directed primarily at the facilities that serve such a system. For the most part, these facilities will be one or more of the following:

- Transfer station

- Materials recovery facility

- Compost facility 
- Waste-to-energy facility

- Sanitary landfill.

In the state of Tennessee, the authority for regulating solid waste management and protecting against negative environmental consequences of such management activities is granted within the Tennessee Solid Waste Management Act of 1991 (T.C.A. 68-211-813 [c] and 68-211-815). The Act was also amended in 1992. The law is administered by the Tennessee Department of Health and Conservation (TDEC) Solid Waste Management Division. The state has adopted solid waste storage, processing and disposal regulations, and performance standards for landfills consistent with the federal Resource Conservation and Recovery Act Subtitle D regulations. Tennessee rule 1200-1-7.09 establishes a waste reduction goal of $25 \%$ by December 31, 1995. In FY 1994, SSWI reported a $70 \%$ recycling/reduction rate.

\section{The Composting Facility}

Composting facility regulations and end product standards are currently being developed for the state of Tennessee. Thus, no Tennessee composting regulations were in place at the time of the signing of the contract between Bedminster and SSWI. However, Article IV of the contract requires the facility to follow the Florida MSW Compost production criteria (Rule 17-709 F.A.C.) as "acceptance criteria." In lieu of a formal permit, TDEC established a set of minimum standards under which the facility was granted "permit by rule" status. TDEC enforces these standards by monthly inspections. One recurring problem has been seepage beneath one of the biofilters. Because the facility processes sludge in addition to MSW, the facility is bound to conform to standards for the final use or disposal of sewage sludge, per section 503 of the Clean Water Act. The Bedminster composting facility's operation plan and end product laboratory results indicate that the product meets the criteria for exceptional quality and unlimited distribution. Odor complaints follow a seasonal pattern. The frequency is estimated to be four to five complaints per month.

\section{The Class I Landfill}

The permit for SSWI's currently operating Class I landfill was issued in June 1993. During FY 1993/1994, the landfill was in general compliance with its operating permit, although several issues of noncompliance have been noted and corrective actions undertaken.

\section{The Class IV Landfill}

The Class IV landfill is permitted as a tire storage area. Under the State of Tennessee Mobile Tire Shredding Plan, in 1992, the county shredded more than 27,000 tires, which are presently being stockpiled pending development of a recycling market. Review of TDEC site inspection reports indicated that violations related to the landfilling of unacceptable materials, including compost and MSW, along with demolition waste, have been noted and corrected.

\section{Special Wastes}

Wastes that are collected within the county, but are deemed unacceptable for disposal at either the Class I or IV landfills, include lead acid batteries and waste oil. Presently, waste oil is collected at several locations and recycled. Lead acid batteries are collected and recycled by local automotive service centers in the region. In 1993, the TDEC developed requirements for temporary locations within counties for the 
collection, sorting, and packaging of HHW. In keeping with the state's 1993 Policy Guide on County Responsibilities for the Tennessee HHW Collection Program, the county selected the Class IV demolition landfill as a temporary HHW collection site. Implementation of the HHW program was expected to occur in 1995. 


\section{Introduction to Condensed Report}

Sevierville is located in Sevier County, Tennessee (the "county"), and is the county seat. As shown in Figure 1, the county is located in the southeast portion of the state approximately 25 miles from Knoxville, Tennessee. Other municipalities in the county include Gatlinburg, Pigeon Forge, and Pittman Center, as shown in Figure 2. The 1990 populations of the municipalities and unincorporated areas are shown in Table 1 .

The county's population has approximately doubled since 1950, with an average increase of about $2 \%$ per year, and the current estimated population is approximately 54,600. The University of Tennessee Department of Sociology has projected the county's population to increase to 63,057 by the year 2000 , approximately a $24 \%$ increase between 1990 and 2000.

The county encompasses approximately 600 square miles. One of the most important physiographic features in the area is the Great Smoky Mountains National Park, a portion of which is included in the eastern part of the county.

As a result of tourism, growth in the local economy in the county has increased dramatically since 1980. According to the state's Bureau of Economic Analysis, Local Planning Assistance, Department of Economic and Community Development (the "department"), there may be as many as 150,000 people in the county during the peak tourist season, or three times the county's 1990 census population.

Sevierville is the largest city in the county with a 1990 population of 7178 . Since 1950, Sevierville's population has increased fourfold, with an annual growth rate of approximately $3.8 \%$. Sevierville's current estimated population is 7500 , and the estimated number of housing units in 1990 was approximately 3321.

According to population projections prepared by the department, Sevierville's population in the year 2000 is projected to be between 6808 and 10601 . The Sevierville Chamber of Commerce anticipates population to be at the upper end of this range, which equates to a $48 \%$ increase between 1990 and 2000 .

During the 1980s, the city of Gatlinburg owned and operated a landfill that serviced the entire county. In 1988, it became apparent that the Gatlinburg landfill would soon reach its capacity and that options other than the existing landfill required investigation. As a result, in December 1988, Sevier Solid Waste, Inc. (SSWI) was formed and authorized under an Interlocal Cooperation Agreement (Interlocal Agreement) between the county and the cities of Sevierville, Gatlinburg, and Pigeon Forge to address waste management in the county. The Charter of Incorporation for SSWI, signed on December 7, 1988, specifies that the corporation is not-for-profit corporation.

The primary purposes of SSWI set forth in the charter are to:

- Receive and administer funds to acquire, construct, equip, and maintain a solid waste landfill and related facilities for the county

- Arrange for the disposal of solid waste through appropriate disposal methods or to contract with others for the hauling or disposal of such solid waste. 


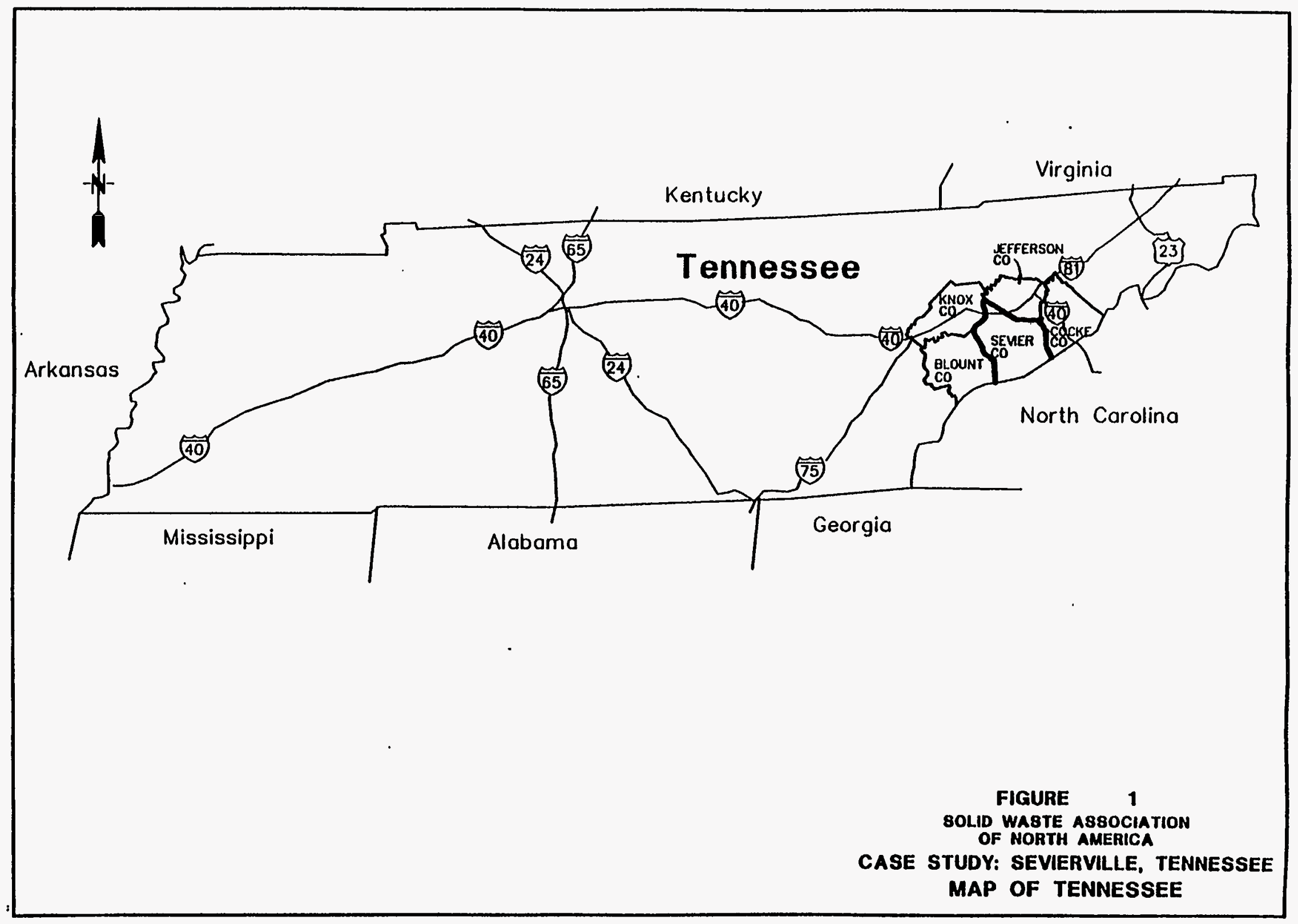

Flgure 1. Map of Tennesseo 


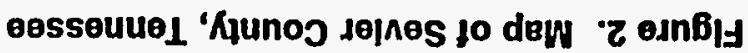

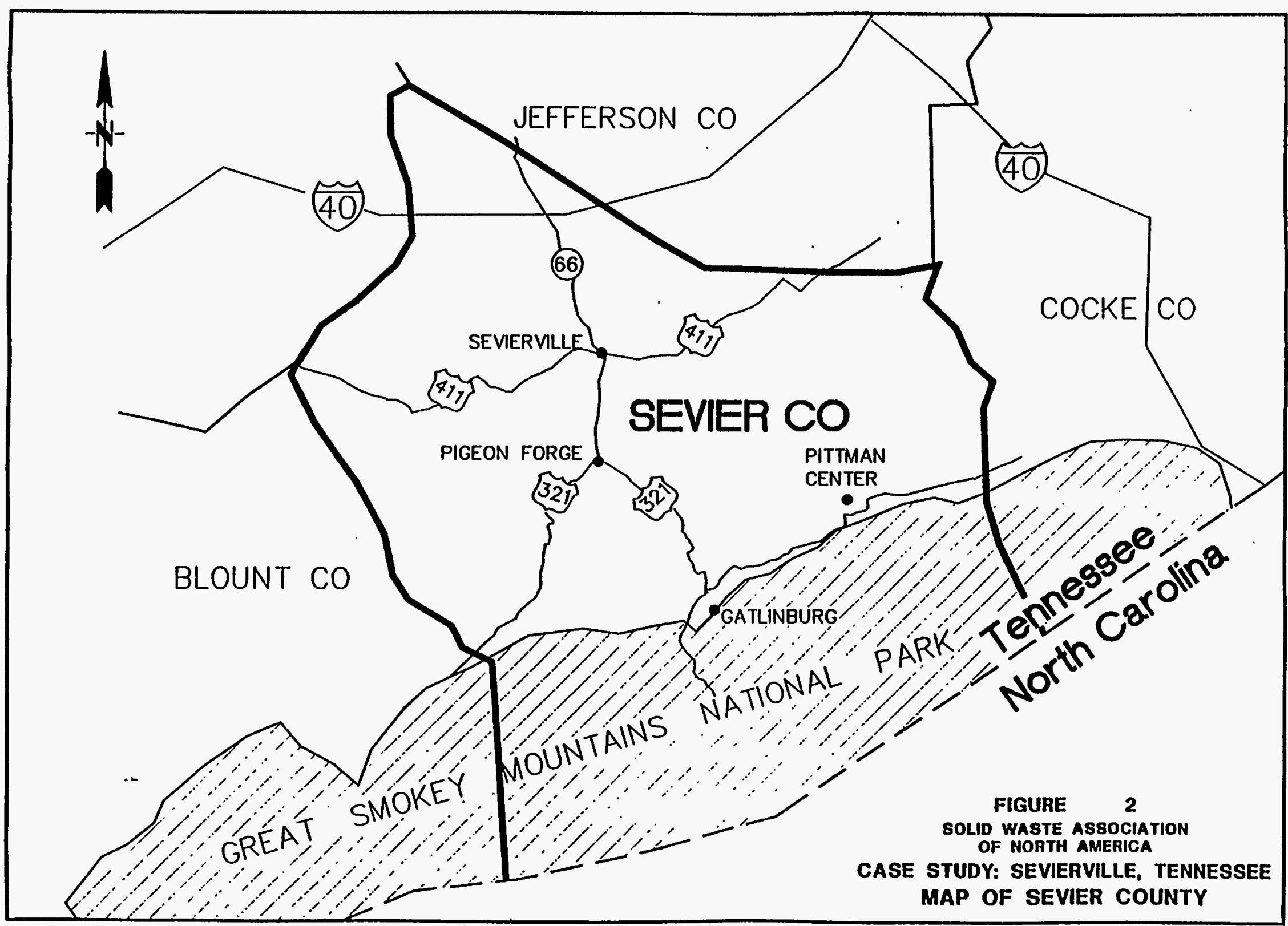


Table 1. 1990 Population in Sevier County

\begin{tabular}{||l|c|c||}
\hline & 1990 Population & Percent of Population \\
\hline Sevierville & 7,178 & $14 \%$ \\
\hline Gatlinburg & 3,417 & $7 \%$ \\
\hline Pigeon Forge & 3,027 & $6 \%$ \\
\hline Pittman Center & 478 & $1 \%$ \\
\hline Unincorporated & 36,943 & $72 \%$ \\
\hline TOTAL & $\mathbf{5 1 , 0 4 3}$ & $\mathbf{1 0 0 \%}$ \\
\hline
\end{tabular}

A Solid Waste Advisory Committee was established in 1988 to further link SSWI with the public.

During 1990, SSWI took over the operation of the landfill from Gatlinburg and began working with the Tennessee Local Planning Assistance Office ("the planning office") to develop and implement a comprehensive solid waste plan for the county. The County Solid Waste Plan was officially adopted in October 1990. The recommendations in the plan provided the foundation for developing the integrated solid waste management facilities currently serving the entire county, which are owned by SSWI.

\section{Sevier County's Integrated Municipal Solid Waste Management System}

\section{System Overview}

The county's current integrated municipal solid waste management (IMSWM) system consists of the following integrated system components:

- Collection of residential and commercial garbage and demolition wastes by the cities and the county

- Collection of old corrugated containers (OCC) from businesses by SSWI, and processing in a recycling warehouse owned and operated by SSWI

- Drop-off collection and recycling of aluminum, plastic, and newspapers by a private hauler under contract with SSWI

- Drop-off collection and recycling of used motor oil by a private hauler

- A mixed waste composting facility-with ferrous metals recovery capabilities-owned by SSWI and operated for SSWI by a private contractor, Bedminster Bioconversion Corporation (Bedminster)

- A new Class I landfill and extension to an old landfill owned and operated by SSWI for the disposal of residue from the compost facility and bypass garbage 
- A Class IV landfill-with ferrous metals, wood, and tire recovery capabilities-owned and operated by SSWI for the recycling and disposal of construction and demolition debris, tires, and other bulky wastes

- Public information and education programs.

SSWI's compost facility, recycling warehouse, and Class I landfill are located on the same site, approximately 5 miles from Sevierville. A site layout is shown in Figure 3. The Class IV landfill and old landfill extension are within close proximity to the compost facility site.

A scale house is located on the SSWI site, and all waste and materials going to SSWI facilities (Class I and IV landfills, compost facility, or recycling warehouse) and materials leaving SSWI facilities are weighed at the scale house.

A description of each of the individual components of the county's IMSWM system follows.

\section{System Component Summary Descriptions}

\section{Collection}

\section{Garbage and Demolition Waste Collection}

Each of the municipalities in the county operate its own garbage collection systems. Door-to-door service is provided in the incorporated areas. In addition, 11 "convenience centers" are provided by the county in unincorporated areas. Convenience centers are drop-off sites for garbage and recyclables. Garbage collected by the cities and the county is taken to the SSWI facilities.

Sevierville's Sanitation Department collects garbage Monday through Friday from all residential dwellings on a once-per-week basis. The approximate number of dwelling units served in FY 1993/1994 was 1950.

Sevierville's Sanitation Department also collects garbage from all commercial businesses and institutions. Collection schedules vary between businesses. Approximately 663 businesses were provided with service in FY 1993/1994.

Managers of multifamily dwellings may choose whether they want commercial dumpster service or residential-type service.

Sevierville's Streets Department also provides collection of demolition (including bulky) waste to residents and businesses. Two dump trucks with clamshells run on regular routes throughout Sevierville for this purpose.

\section{Commercial OCC Collection and Processing}

SSWI has placed dumpsters behind more than 40 businesses in the county for separate collection of OCC. Approximately $75 \%$ of the dumpsters are located in Pigeon Forge, with the balance in Gatlinburg and 
Sevierville. A 25-cubic-yard side loader operated by an SSWI employee collects the OCC on a twice-per week basis and brings it to the recycling warehouse for baling.

The recycling warehouse is a 12,000 -square-foot building that was completed in 1993. At the warehouse, the OCC is baled in 1500-pound bales, and truckload quantities (20 tons) are hauled by Knoxville Recycled Fiber Company to Rock Tenn Paper Company in Chattanooga for recycling. The OCC is sold to Rock Tenn under a long-term contract.

\section{Drop-Off Recyclables Collection}

SSWI provides drop-off collection of newspaper, aluminum, and HDPE and PET plastics for recycling at six locations throughout the County through a contract with Waste Management. One of six drop-off locations is in Sevierville. The compartmentalized roll-off containers used at the sites are owned by Waste Management.

Waste Management collects the recyclables from the drop-off sites and delivers them to Lakeway Recycling in Morristown, approximately 40 miles from Sevierville. Lakeway processes the materials and sells them to multiple remanufacturers.

\section{Drop-Off Recyclables Collection Drop-Off Used Motor Oil Collection}

Eleven drop-off sites for used motor oil are located throughout the county. Four of these drop-off sites are the same as the recyclables drop-off locations. Only one drop-off site for used oil is located in Sevierville, and it is not at the same location as the recyclables drop-off. Industrial Oil Service of Knoxville supplies the waste motor oil containers and provides the collection services. No cost is incurred by SSWI or the local governments for this program.

\section{Composting Facility}

SSWI contracted with Bedminster of New Jersey in September 1991 to build a composting facility and operate it for 5 years. The facility began operations in October 1992.

The composting facility receives garbage and sewage sludge from all of the county's residents and 8 million yearly visitors. The design capacity for the facility is 225 tons per day total, comprised of 150 tons of municipal solid waste (MSW) and 75 tons of sewage sludge. The facility also receives some wastewater treatment grease trap waste and restaurant grease, as well as sludge imported from outside the county. A materials flow diagram and floor plan for the composting facility are shown in Figures 4 and 5 .

Material received at the facility is weighed in at the county-operated scale house. Loads containing construction and demolition wastes are directed to the Class IV landfill. Tip floor workers remove bulky items and hazardous items from the garbage. The remaining material is fed via front-end loaders into hydraulic ram pits. The ram pits feed material into one of three rotating drum digesters, which are each 184 feet long and 12 feet in diameter. Each digester is separated into three chambers, corresponding to three distinct phases of microbial activity. 


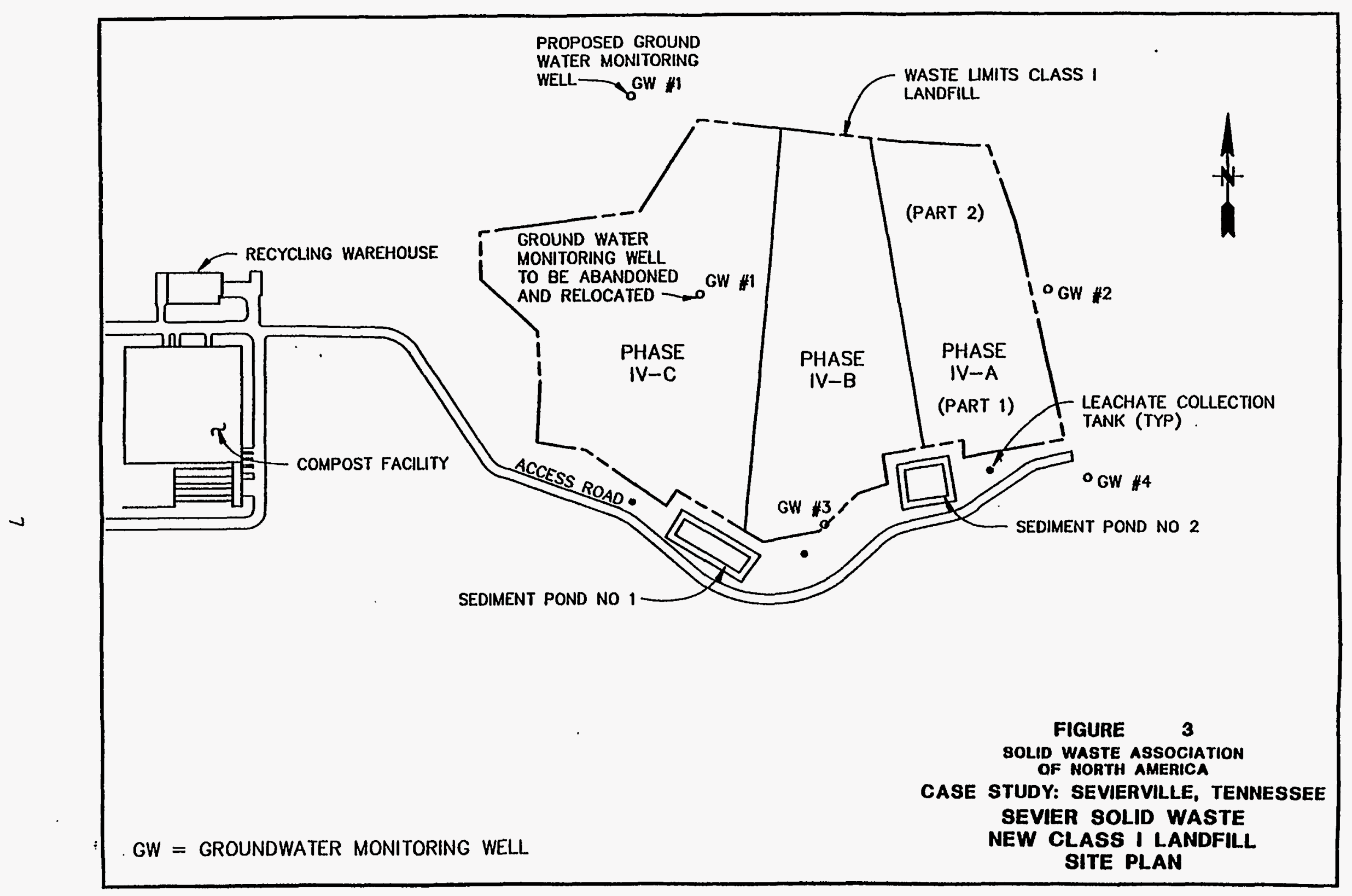

Flgure 3. Sovler Solld Waste Now Class I Landill Site Plan 
Material exiting the digesters is dropped onto a conveyor that feeds the material into the primary trommel screen, which separates the nonorganic (including plastic containers, film plastics, and tin cans) from the organic fraction. Approximately $30 \%$ of the material is rejected as nonorganic material at the primary trommel. The nonorganic fraction is passed under a magnetic belt separator to pull out the ferrous metals, which are currently being sold to a scrap metals company in Rockwood, Tennessee. The remaining residue is disposed of at the adjacent Class I landfill.

The remaining organics are formed into bays (piles) in the aeration building. The retention time of material on the aeration floor is 4 to 6 weeks. Air is forced through the piles to provide oxygen to the microbes and to regulate temperatures within the piles. From the aeration building, material is conveyed to the final screening area, where it is refined into finished product.

Process air from the curing building and digesters passes through biofilters prior to being dispersed. The biofilter media is 3 feet deep and rests on top of perforated pipes on a gravel base. The biofilter is comprised of a mixture of wood chips, mulch (ground bark), finished compost, and sand. Odorous compounds are scrubbed from the process air by the filter media.

Finished compost goes to some form of beneficial use, including agricultural research, landscaping, athletic fields, and parks. The majority of the material is given away in an effort to develop markets for the material. The price for the material that is sold is approximately $\$ 10.00$ per ton.

\section{Class I Landfills}

SSWI operated two landfills for the disposal of bypass waste and residue from the composting facility during FY 1993/1994. (Bypass waste is waste that is not processed through the composting facility on occasion due to a lack of capacity, and residue consists primarily of plastics screened out of the composting process.) Between June and October 1993, residue and bypass waste were disposed of at an extension to the old county landfill (Old Landfill Extension). On closure of the Old Landfill Extension, bypass waste and residue were disposed of in a new Class I landfill located on the same site as the composting facility and recycling warehouse.

The new Class I landfill's design meets the requirements of the Resource Conservation and Recovery Act (RCRA) Subtitle D and consists of three permitted phases: Phases IV A, B, and C. These phases are shown in Figure 3. The combined size of Phase IV A, B, and C is approximately 25 acres.

Phase IV A reportedly has three liners and a leachate collection system. Each of the three phases of Phase IV will have independent leachate collection tanks. A vacuum truck is used to remove leachate from the leachate collection system. The leachate is taken to wastewater treatment plants in Gatlinburg, Sevierville, and Pigeon Forge for treatment and disposal.

The clay used to construct the landfill liner and the daily cover material is located on site. In FY 1994/1995, in an effort to conserve landfill space, SSWI began using a geomembrane for daily cover. 


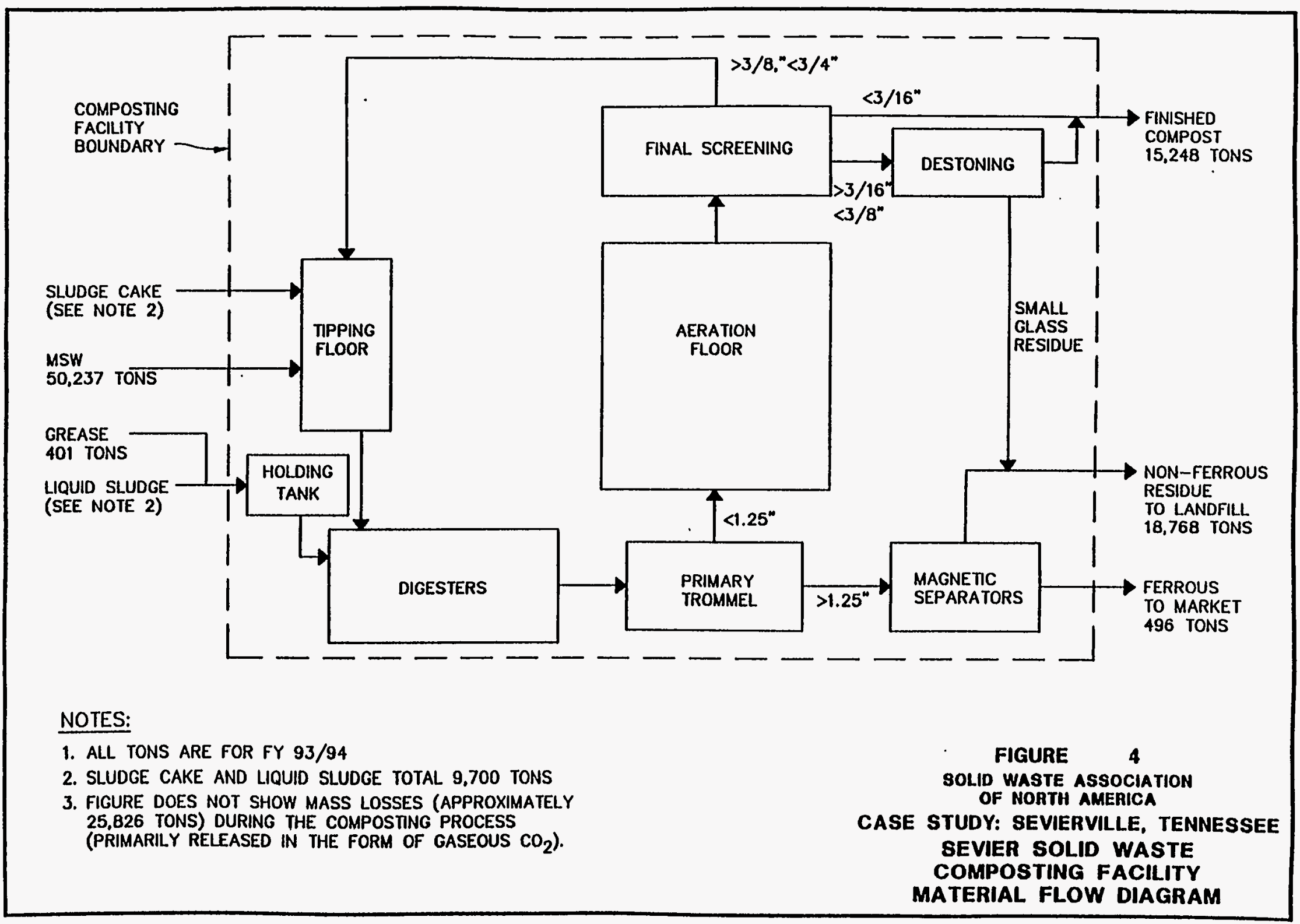

Flgure 4. Sovier Solid Waste Composting Facility Material Flow Dlagram 


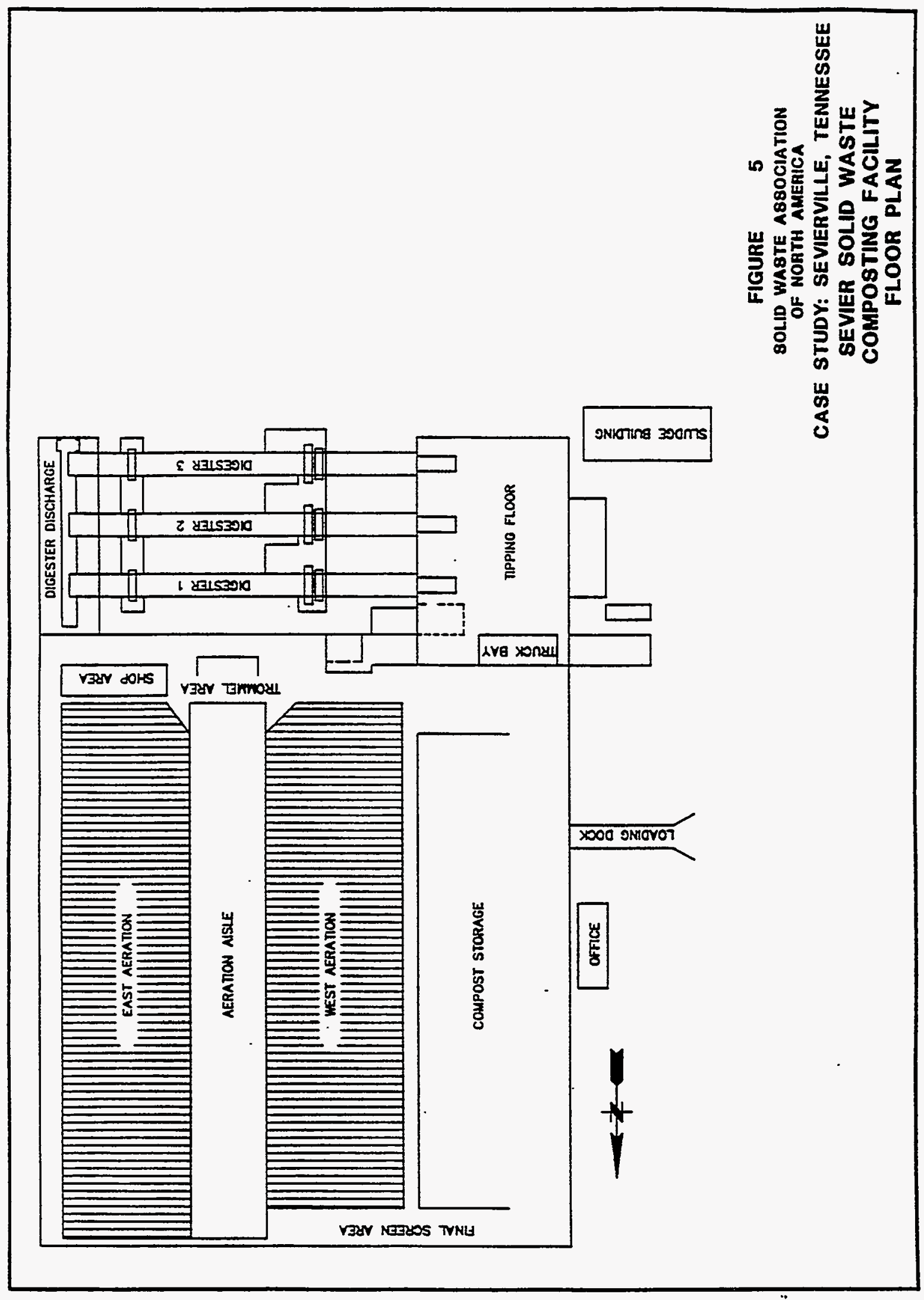

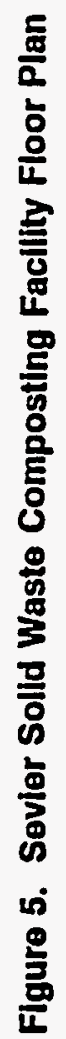


During construction of Phase IV A, Part 1, an access road was constructed for the entire Phase IV landfill development, and a sedimentation pond was constructed, which will serve Phase IV A and a portion of Phase IV B. The sedimentation pond is part of the surface water control system for the Phase IV landfill. Groundwater monitoring wells were also installed, and groundwater from the wells is sampled and analyzed to determine groundwater characteristics.

\section{Class IV Landfill}

In April 1993, SSWI began operating a Class IV demolition landfill. The only types of wastes accepted at this site are construction and demolition waste and bulky waste, including tires. The size of the site is approximately 14 acres; three of these acres are used for landfilling. This landfill is not lined, and cover is applied once per month.

Metal items including white goods are placed in a roll-off container and hauled to an intermediate processor. Wood pallets are stockpiled and given to a local business to be reused. Other wood waste, such as brush, is mulched by using a tub grinder and given away to local residents free of charge.

The Class IV landfill site also contains a state-permitted tire storage area with a maximum capacity of approximately 30,000 tires. Tires are shredded periodically by a contractor hired by the state and are stockpiled for future market development.

\section{Public Information and Education Programs}

SSWI developed an educational program in conjunction with the 4-H clubs in the county to teach children in the schools about the county's solid waste system.

SSWI has developed a scale model of the composting facility, which is rotated throughout the county in different locations (including schools, libraries, and welcome centers). In addition, several thousand visitors from all over the country visit the compost facility each year. A local library in Gatlinburg developed a brochure to answer questions regarding the facility and the county's overall MSW management program, and developed a speakers bureau to assist local organizations in obtaining speakers such as the general manager and board members of the SSWI for their meetings.

\section{MSW Collected, Processed, and/or Disposed of in Sevierville}

A total of approximately 72,300 tons of waste, 66,700 tons of waste from the county, and 5600 tons of imported sludge were managed in SSWI programs in FY 1993/1994. Of this amount, approximately 13,800 tons (19\% by weight) were from Sevierville. No solid waste was reportedly exported out of the county, and sludge was the only type of imported waste.

A comparison of Sevierville and total county waste quantities, including imported sludge, is shown in Table 2 by waste category. Figure 6 is a waste flow diagram for the county, which includes FY 1993/1994 tonnages, and Figure 7 is a waste flow diagram for waste generated in Sevierville, which includes FY 1993/1994 tonnages. 
The amount of the total waste stream that was diverted from landfill disposal through the SSWI programs during FY $1993 / 1994$ was 43,500 tons or $60 \%$ by weight. The amount of Sevierville's waste stream that was diverted from landfill disposal through the SSWI programs during FY 1993/1994 was 8400 tons or $61 \%$ by weight.

\section{Compost Facility}

Based on scale house records, a total of approximately 61,000 tons of waste as delivered for composting at the SSWI site in FY 1993/1994. The total waste delivered was comprised of approximately 51,000 tons of garbage, 4,500 tons of grease and sludge generated within the county and 5600 tons of sludge imported from outside the county.

Bedminster records show that approximately 18,800 tons of residue were produced by the compost facility during FY 1993/1994, and the estimated residue produced by Sevierville was 3600 tons or $19 \%$ of the total composting residue.

Scalehouse records indicate that about 500 tons of ferrous metals were recovered from the garbage processed by the composting facility or 100 tons from Sevierville's garbage. The recovered ferrous metals quantities were equal to about $1 \%$ by weight of the composted garbage.

According to Bedminster records, approximately 15,300 tons of compost were produced and marketed during FY 1993/1994, with 2900 tons or $19 \%$ of the total compost produced coming from Sevierville's garbage.

The compost facility diverted a total of 41,600 tons of waste (including ferrous metals), including 8,000 tons of Sevierville waste, from landfill disposal. This equates to approximately a $70 \%$ reduction in weight of the garbage, sludge, and grease processed in the composting facility (compared to the total estimated waste stream reduction of approximately $60 \%$ for the entire system as detailed earlier in this section).

\section{Class I Landfills}

Scale house records indicate approximately 19,600 total tons of bypass waste and residue from the compost facility were disposed of in the Class I landfills, of which 800 tons were bypass waste and 18,800 tons were residue.

The estimated amount of bypass waste and residue from Sevierville's waste was approximately 200 tons and 3,600 tons, respectively, for a total of approximately 3,800 tons. For both the total county and Sevierville, the amount of materials disposed of in the Class I landfills during FY 1993/1994 is estimated to be $96 \%$ by weight residue and $4 \%$ bypass waste. 
Table 2. Comparison of Total County and Sevierville Waste Quantities (FY 1993/1994)

\begin{tabular}{|c|c|c|}
\hline \multirow[b]{2}{*}{ Type } & \multicolumn{2}{|c|}{$\begin{array}{c}\text { Waste Quantities Handled by SSWI } \\
\text { Programs }\end{array}$} \\
\hline & Total System & City of Sevierville \\
\hline Garbage & $51,043^{a}$ & $10,280^{b}$ \\
\hline Recyclables: & 464 & 62 \\
\hline Drop-Off & $220^{c}$ & $31^{d}$ \\
\hline Commercial Corrugated & $244^{\mathrm{a}}$ & $31^{e}$ \\
\hline HHW (Used Motor Oil) & $10^{\mathrm{f}}$ & $1^{d}$ \\
\hline Sludge/Grease & $10,101^{a}$ & $1,503^{b}$ \\
\hline Sludge/Grease from Local Community(s) & $4,489^{a}$ & $1,503^{b}$ \\
\hline Imported Sludge & $5,612^{a}$ & N/A \\
\hline TOTAL & 72,326 & 13,751 \\
\hline
\end{tabular}

Notes:

"Taken from scalehouse records compiled by SSWI.

${ }^{b}$ Taken from scalehouse records compiled by Sevierville.

'Estimated by SSWI.

dEstimated based on total county tonnages by assuming that quantities are proportional to population.

eSSWI estimated that 75\% of commercial corrugated was collected in Pigeon Forge. One-half of the remaining 25\% was assumed to come from Sevierville.

'SSWI estimated that approximazely 2700 gallons were collected. This quantity was converted to tons, assuming that used motor oil has a density of 54.9 pounds per cubic foot. 


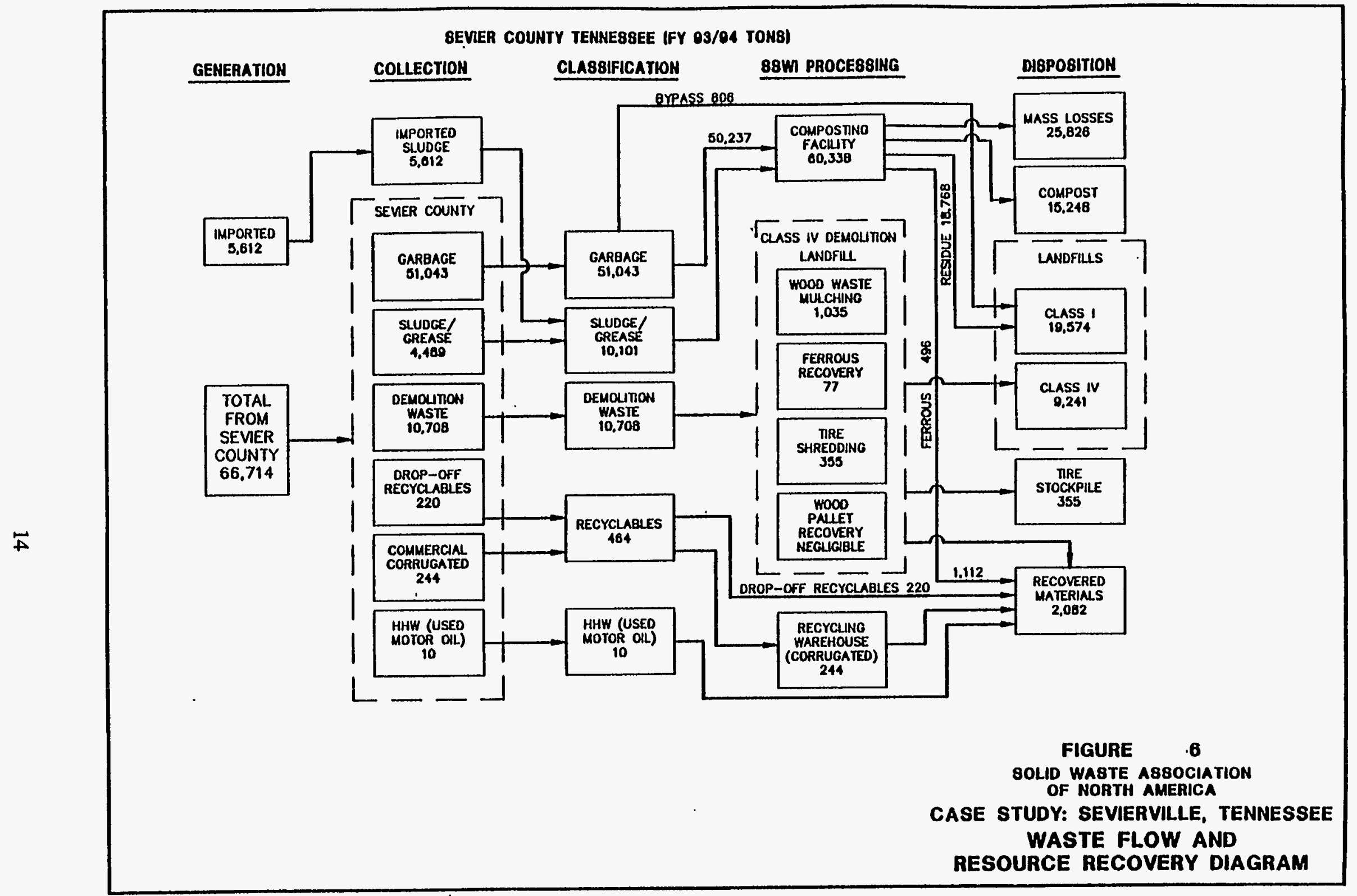

Figure 6. Sevler County Waste Flow and Resource Recovery Dlagram 


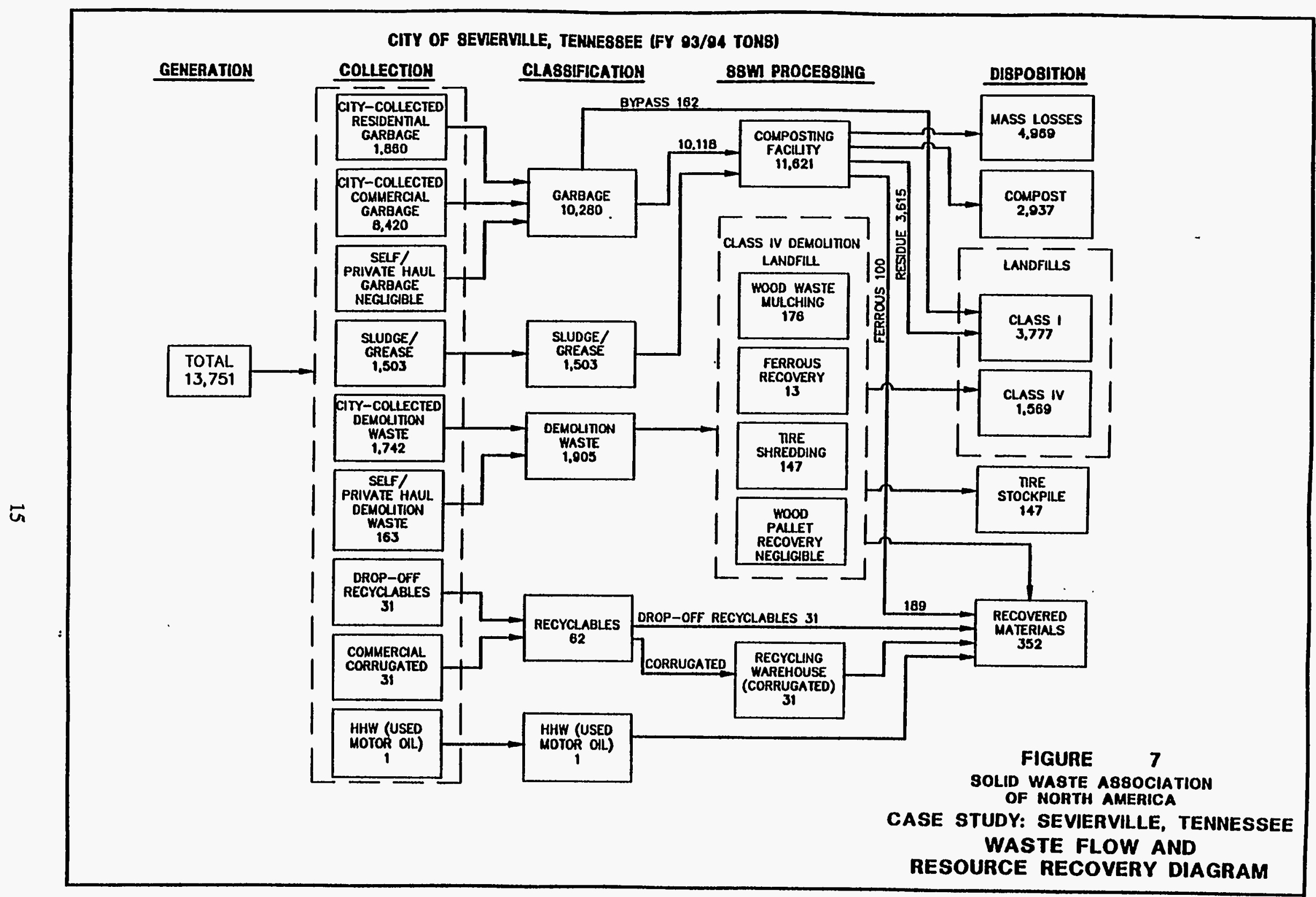

Figure 7. City of Sevlerville Waste Flow and Resource Recovery Dlagram 


\section{Class IV Landfill}

Table 2 shows the quantities of demolition waste delivered to the Class IV landfill during FY 1993/1994; however, data on the quantities of wood waste recovered at the Class IV landfill during FY 1993/1994 were not available. Therefore, estimates were made based on the Regional Plan. It was estimated that $10 \%$ of the demolition waste (exclusive of tires) was recovered as mulched wood waste, resulting in approximately 1000 total tons of wood waste being mulched on a county-wide basis during FY 1993/1994. The quantity of wood waste from Sevierville that was mulched was estimated at approximately 180 tons. Data on the quantities of wood pallets recovered at the landfill are not available but were assumed to be negligible.

Approximately 80 tons of ferrous metals were recovered at the Class IV landfill during FY 1993/1994 based on records from the intermediate processor, with an estimated 10 tons coming from Sevierville.

The total amount of demolition waste diverted from disposal through recovery and stockpiling programs at the Class IV site during FY 1993/1994 was 1470 tons. The amount recovered from Sevierville demolition waste was estimated to be 340 tons. These amounts are equivalent to approximately $14 \%$ by weight of the total demolition waste and $18 \%$ of Sevierville's demolition waste delivered.

\section{Recyclables Drop-Off and Commercial Corrugated Programs}

The amount of materials diverted from disposal through the recyclables drop-off program and commercial comugated program represented less than $1 \%$ by weight of the total amount of materials diverted for both Sevierville and the entire County.

\section{HHW (Used Oil Program)}

SSWI estimates that approximately 2700 gallons (10 tons) of used motor oil were collected through the 11 drop-off sites in the county during FY 1993/1994, with an estimated quantity of 1 ton coming from Sevierville.

\section{Recovered Materials and Compost Markets}

Table 3 shows the intermediate processors, remanufacturers, and reusers for the recovered materials from the county's waste stream. Residue quantities from intermediate processors and end users related to processing/using these materials were not taken into account in this analysis.

\section{Cost of MSW Management in the City of Sevierville}

\section{Apportionment of Waste Stream}

Only a portion of the total solid waste streams described previously are included in the economic analyses presented herein. The reason for limiting the tonnage included in the analysis is to include only that portion of the waste streams considered to be MSW and for which the total cost of collection, processing, 
Table 3. Markets for Recovered Materials and Compost in FY 1993/1994

\begin{tabular}{|c|c|c|c|c|c|c|c|c|c|c|c|}
\hline \multirow[b]{2}{*}{$\begin{array}{l}\text { Recuvered } \\
\text { Material }\end{array}$} & \multirow[b]{2}{*}{$\begin{array}{c}\text { Total } \\
\text { Tonnage }\end{array}$} & \multirow[b]{2}{*}{$\begin{array}{c}\text { City } \\
\text { Tonnage }\end{array}$} & \multicolumn{4}{|c|}{ Intermediate Processing } & \multicolumn{5}{|c|}{ Remanufacturing/End Usage } \\
\hline & & & Processor & Location & $\begin{array}{c}\text { Distance } \\
\text { from } \\
\text { SSWI site } \\
\text { (miles) }\end{array}$ & $\begin{array}{c}\text { Mode of } \\
\text { Transport } \\
\text { to } \\
\text { Processor }\end{array}$ & $\begin{array}{c}\text { Remanufacturer/ } \\
\text { End User }\end{array}$ & Location & $\begin{array}{l}\text { Distance } \\
\text { from } \\
\text { Processing } \\
\text { Site (mi) } \\
\end{array}$ & $\begin{array}{c}\text { Mode of } \\
\text { Transport } \\
\text { to End } \\
\text { Use }\end{array}$ & End Use \\
\hline $\begin{array}{l}\text { Newspaper from } \\
\text { Drop-Offs }\end{array}$ & $220^{\mathrm{a}}$ & $31^{2}$ & $\begin{array}{l}\text { Lakeway } \\
\text { Rocycling }\end{array}$ & $\begin{array}{l}\text { Morristown, } \\
\text { TN }\end{array}$ & 40 & $\begin{array}{l}\text { Roll-Off } \\
\text { Truck }\end{array}$ & Bowater & Calhoun, TN & 115 & $\begin{array}{l}\text { Tructor- } \\
\text { Trailer }\end{array}$ & Newsprint \\
\hline $\begin{array}{l}\text { Aluminum from } \\
\text { Drop-Offs }\end{array}$ & & & $\begin{array}{l}\text { Lakeway } \\
\text { Recycling }\end{array}$ & $\begin{array}{l}\text { Morristown, } \\
\text { TN }\end{array}$ & 40 & $\begin{array}{l}\text { Roll-Off } \\
\text { Truck }\end{array}$ & Alcoa & $\begin{array}{l}\text { Maryville, } \\
\text { TN }\end{array}$ & 55 & $\begin{array}{l}\text { Tractor- } \\
\text { Trailer }\end{array}$ & Can Sheel \\
\hline $\begin{array}{l}\text { Plastics from } \\
\text { Drop-Offs }\end{array}$ & & & $\begin{array}{l}\text { Lakeway } \\
\text { Recycling }\end{array}$ & $\begin{array}{l}\text { Morristown, } \\
\text { TN }\end{array}$ & 40 & $\begin{array}{l}\text { Roll-Off } \\
\text { Truck }\end{array}$ & Varies & Varies & Varies & $\begin{array}{l}\text { Tractor- } \\
\text { Trailer }\end{array}$ & Varies \\
\hline $\begin{array}{l}\text { Commercial } \\
\text { OCC }\end{array}$ & 244 & 31 & SSWI & $\begin{array}{l}\text { SSWI Site } \\
\text { Recycling } \\
\text { Warehouse }\end{array}$ & 0 & Not Appl. & Rock-Tenn & $\begin{array}{l}\text { Chattanooga, } \\
\text { TN }\end{array}$ & 130 & $\begin{array}{l}\text { Tractor- } \\
\text { Trailer }\end{array}$ & Buxboard \\
\hline Compost & 15,248 & 2,937 & SSWI & $\begin{array}{l}\text { SSWI Site } \\
\text { Composting } \\
\text { Facility } \\
\end{array}$ & Not Appl. & Not Appl. & Varies & Varies & Varies & $\begin{array}{l}\text { Not } \\
\text { Available }\end{array}$ & $\begin{array}{l}\text { Soil } \\
\text { Amendment }\end{array}$ \\
\hline Used Motor Oil & 10 & 1 & Industrial Oil & $\begin{array}{l}\text { Knoxville, } \\
\text { TN }\end{array}$ & 25 & Unknown & Unknown & Unknown & Unknown & $\begin{array}{l}\text { Not } \\
\text { Available }\end{array}$ & Unknown \\
\hline $\begin{array}{l}\text { Ferrous Metals } \\
\text { from Compost } \\
\text { Facility }\end{array}$ & 496 & 100 & $\begin{array}{l}\text { Southern } \\
\text { Alloy }\end{array}$ & $\begin{array}{l}\text { Rockwood, } \\
\text { TN }\end{array}$ & 80 & $\begin{array}{l}\text { Tractor- } \\
\text { Trailer }\end{array}$ & Varies & Varies & Varies & $\begin{array}{l}\text { Rail, } \\
\text { Truck and } \\
\text { Barge }\end{array}$ & $\begin{array}{l}\text { Stecl } \\
\text { Product }\end{array}$ \\
\hline $\begin{array}{l}\text { Ferrous Metals } \\
\text { from Class IV } \\
\text { Landfill }\end{array}$ & 77 & 13 & $\begin{array}{l}\text { Morristown } \\
\text { Shredders }\end{array}$ & $\begin{array}{l}\text { Morristown, } \\
\text { TN }\end{array}$ & 40 & $\begin{array}{l}\text { Roll-off } \\
\text { Truck }\end{array}$ & Florida Steel & $\begin{array}{l}\text { Knoxville, } \\
\text { TN }\end{array}$ & 40 & $\begin{array}{l}\text { Tractor- } \\
\text { Trailer }\end{array}$ & Steel Rebiu \\
\hline Wood Pallets & Neg. & Neg. & Not Appl. & Not Appl. & Not Appl. & Not Appl. & $\begin{array}{l}\text { Newsport Pallet } \\
\text { (Reuser) }\end{array}$ & $\begin{array}{l}\text { Newsport, } \\
\text { TN }\end{array}$ & 40 & $\begin{array}{l}\text { Not } \\
\text { Available }\end{array}$ & Pallets \\
\hline $\begin{array}{l}\text { Wood Waste } \\
\text { Mulch }\end{array}$ & 1,035 & 176 & Not Appl. & Not Appl. & Not Appl. & Not Appl. & Local Residents & $\begin{array}{l}\text { Sevier } \\
\text { County }\end{array}$ & Varies & $\begin{array}{l}\text { Not } \\
\text { Available }\end{array}$ & Mulch \\
\hline Total & 17,330 & 3,289 & & & & & & & & & \\
\hline
\end{tabular}

Note:

adata not available to break out total drop-off tonnages between materials. 
composting, and disposal is known (analyzed MSW). Failure to limit the economic analysis to the tonnage and costs associated with analyzed MSW would bias the results and could result in misleading conclusions.

The analyzed MSW analyzed herein excludes the following components:

- Self-hauled recyclables and household hazardous waste (HHW) (used motor oil) collected through the drop-off collection system, and garbage delivered into the SSWI system by private or self-haulers

- Management of demolition waste (including bulky waste)

- Sludge and grease.

Please note that the tonnages of sludge and grease processed at the composting facility are excluded from analyzed MSW, but the costs associated with processing sludge and grease are included in the economic analyses.

Table 4 shows the FY 1993/1994 tonnages of the components of both the total MSW and analyzed MSW.

Table 4. City of Sevierville FY 1993/1994 Total Waste and Analyzed SW Tonnages by Component

\begin{tabular}{|c|c|c|}
\hline MSW Components & $\begin{array}{c}\text { Total MSW } \\
\text { (tons) }\end{array}$ & $\begin{array}{c}\text { Analyzed MSW } \\
\text { (tons) }\end{array}$ \\
\hline \multicolumn{3}{|l|}{ Garbage } \\
\hline City Collect to Composting Facility ${ }^{a}$ & 10,280 & 10,280 \\
\hline Self/Private Hauled to Composting Facility ${ }^{b}$ & Negligible & 0 \\
\hline Subtotal of Garbage & 10,280 & 10,280 \\
\hline \multicolumn{3}{|l|}{ Recyclables } \\
\hline Drop-off Collected to Private Processors ${ }^{c}$ & 31 & 0 \\
\hline Commercial OCC $^{\mathrm{d}}$ & 31 & 31 \\
\hline Subtotal of Recyclables & 62 & 31 \\
\hline Household Hazardous Waste ${ }^{e}$ & 1 & 0 \\
\hline Demolition Waste & 1,905 & 0 \\
\hline Sludge/Grease & 1,503 & 0 \\
\hline TOTAL & 13,751 & 10,311 \\
\hline
\end{tabular}

Notes:

${ }^{4}$ Includes residential and commercial garbage.

${ }^{b}$ Consists of garbage hauled by privately operated independent haulers and self-haulers.

'Self-hauled to drop-off collection sites.

${ }^{d}$ Collected by hauler under contract to SSWI.

eSelf-hauled to collection sites. 


\section{Total Costs of Waste Management}

To determine gross and net costs attributable to analyzed MSW, it was first necessary to determine SSWI's and Sevierville's total costs for managing the waste streams.

The gross and net costs were determined by performing the following steps:

- Determining the SSWI's total reported costs and revenues

- Adjusting SSWI's total reported costs and revenues as necessary to satisfy the requirements of this study

- Determining Sevierville's municipal collection costs

- Estimating the costs of garbage containers (plastic bags, trash cans, and other containers) used to collect garbage, which are purchased by residents and businesses

- Combining SSWI adjusted costs and revenues, Sevierville costs, and costs of containers.

Appendix D to the report provides a detailed explanation of the preceding steps.

\section{SSWI Reported and Adjusted Costs}

Table 5 presents a summary of SSWI costs and revenues. Table C-1 in Appendix C of the report (Methodology and Data Used to Calculate Total Gross and Net Costs) provides additional detail on these reported and adjusted costs.

Adjustments made to SSWI reported costs are listed below.

- In accordance with the methodology established for these case studies, two adjustments were made to the "Reported" column:

- Reported "depreciation" and "amortization" were treated as "annualized capital costs" in the adjusted column.

- Only recovered material revenues were considered revenues. Other revenues were shown as costs to the system.

- Operating costs were increased to include labor cost for the scale house operator, who is paid by the county (not SSWI).

- Capital costs for the composting facility were also adjusted to account for composting facility costs incurred by Bedminster. 
Table 5. SSWI Revenues and Expenses, Year Ending June 30, 1994

\begin{tabular}{|c|c|c|}
\hline & $\begin{array}{c}\text { Reported } \\
\text { Revenues/(Expenses) }^{\mathbf{a}} \\
\end{array}$ & $\begin{array}{c}\text { Adjusted } \\
\text { Revenues/(Expenses) }\end{array}$ \\
\hline \multicolumn{3}{|l|}{ Operating Income: } \\
\hline Recyclables and Compost Revenue & $\$ 11,817^{b}$ & $\$ 18,117^{\mathrm{c}}$ \\
\hline Total Operating Revenue & 11,817 & 18,117 \\
\hline \multicolumn{3}{|l|}{ Operating Expenses: } \\
\hline Personnel Cost & $\$ 289,180$ & $\$ 322,815^{d}$ \\
\hline Supplies & 11,161 & 15,161 \\
\hline Maintenance & 68,576 & 68,576 \\
\hline General Services & 159,919 & 159,919 \\
\hline Landfill Closure/Post Closure Costs & 530,740 & $530,740^{\mathrm{e}}$ \\
\hline Other & 48,864 & 48,864 \\
\hline Recycling Expenses & 41,022 & 41,022 \\
\hline Composting Expenses & 956.354 & $962,654^{f}$ \\
\hline Total Operating Expenses & $\$ 2,109,816$ & $\$ 2,149,751$ \\
\hline \multicolumn{3}{|l|}{ Net Operating Income (loss) before } \\
\hline Depreciation and Amortization & $(\$ 2,097,999)$ & $(\$ 2,131,634)$ \\
\hline Less Depreciation & 615,608 & 0 \\
\hline Less Amortization & 18,521 & 0 \\
\hline Annualized Cost Capital & 0 & $1,301,981^{\mathrm{g}}$ \\
\hline Net Operating Income (Loss) & $(\$ 2,732,128)$ & $(\$ 3,433,614)$ \\
\hline \multicolumn{3}{|l|}{ Nonoperating Income (Expense): } \\
\hline Investment Income & $\$ 20,512$ & 0 \\
\hline Bond Interest Expense & $(572,471)$ & 0 \\
\hline Total Nonoperating Income (Expense) & $(\$ 551,959)$ & $\mathbf{0}$ \\
\hline Net Income Loss & $(\$ 3,284,087)$ & $(\$ 3,433,615)$ \\
\hline
\end{tabular}

Notes:

"Source: SSWI's "Financial Statements, June 30, 1994 and 1993." Types of reported costs and revenues used in this study are consistent with those used in other case studies.

bother revenues consist of recycling revenues and miscellaneous income. Revenue shown represents recycling revenues only ( $\$ 8974$ for OCC and $\$ 2844$ for ferrous metals recovered at the Class IV landfill). Miscellaneous income was taken out.

'Adjusted to account for revennes (\$6300) from ferrous metals sales from the composting facility.

${ }^{\mathrm{d}}$ Reflects $\$ 33,635$ adjustment for scale house operator.

'Due to a lack of information. these costs were not calculated using the methodology developed in the other case studies.

fFotnote [3] adjusted the operating income to account for $\$ 6300$ in ferrous metals revenue for ferrous metals recovered by Bedminster at the compost facility. This adjustment shows the $\$ 6300$ as an increased cost to SSWI.

${ }^{B}$ Reflects substintion of annualized capital costs for depreciation/amoctization and net nonoperating expenses. Line item is comprised of the following:

\section{Description}

Annualized Class I, Phase IV A Capital Costs

Annualized Additional Composting Facility Capital Costs

Annualization of Reported Amortization Items

Annualization of Reported Depreciation Items

TOTAL Annualized Capital Costs

**Estimate provided by Bedminster (not documented).
$\$ 130,000$

$113,277^{* *}$

33.798

$\$ 1.024 .906$

$\$ 1,301.981$ 


\section{City Reported Costs}

The total cost of collection was determined by compiling information provided by Sevierville and making estimates and assumptions when needed. Table 6 shows an itemized breakdown of the actual FY 1993/1994 expenditures for garbage collection in Sevierville.

Table 6. Total Gross Sevierville Cost of Collection (FY 1993/1994 \$)

\begin{tabular}{|c|c|}
\hline Sanitation Fund & $\$ 229,147$ \\
\hline City Garage & 7,435 \\
\hline Vehicle Annualized Capital Costs & 81,839 \\
\hline$G \& A^{a}$ & 63,684 \\
\hline TOTAL & $\$ 382,106$ \\
\hline
\end{tabular}

\section{Costs of Bags, Cans, and Containers}

In addition to the expenses incurred by Sevierville and SSWI, individuals and businesses incur the costs of plastic bags, garbage cans, and containers used in garbage collection. Because a drop-off program is used in Sevierville for recyclables collection, it is reasonable to assume that containment costs to the residents is minimal. However, SSWI provides for the containers used in the commercial OCC collection program, and this cost was reflected in the analysis of SSWI's costs. Therefore, the cost of using bags, cans, and containers must be included in the cost of managing garbage. To estimate these costs, assumptions were used, consistent with previous case studies, resulting in an estimated cost of $\$ 95,038$.

\section{Combined Costs and Revenues}

The combined SSWI adjusted costs and revenues, Sevierville costs, and costs of containers result in the total gross and net costs shown in Table 7.

Table 7. Total Gross and Net Costs of IMSWM System (FY 1993/1994 \$)

\begin{tabular}{||lcc||}
\hline & Gross & Net \\
\hline SSWI & $\$ 3,451,732$ & $\$ 3,433,615$ \\
Sevierville Municipal Collection & 382,106 & 382,106 \\
Bag/Can/Container Costs & 95,038 & 95,038 \\
\hline TOTAL & $\$ \mathbf{\$ 4 , 0 7 5 , 2 2 7}$ & $\mathbf{\$ 4 , 0 5 7 , 1 1 0}$ \\
\hline
\end{tabular}




\section{Total Costs of Analyzed MSW Management and Costs by Functional Area}

Table 8 presents the results of the allocation of gross costs on a functional basis and the amount of the gross costs determined to be attributable to analyzed MSW.

The amounts of revenues received by SSWI from the sale of compost and recyclables were next analyzed to determine the portion that should be attributed to analyzed MSW. Tonnage figures were used when necessary to determine the portion of total revenues that should be allocated to analyzed MSW. Table 9 presents the results of this allocation of revenues on a functional basis and the amount of the revenues determined to be attributable to analyzed MSW.

Table 10 contains gross costs of managing analyzed MSW by functional area, and Table 11 contains net costs of managing analyzed MSW by functional area after deducting revenues shown in Table 9 from gross costs shown in Table 10. 
Table 8. Total Gross Costs of Sevierville's IMSWM System Allocated by Functional Area (FY 1993/1994 \$)

\begin{tabular}{|c|c|c|c|c|c|c|c|c|c|c|c|c|}
\hline Description & $\begin{array}{l}\text { Garbage } \\
\text { Collection }\end{array}$ & $\begin{array}{l}\text { Class I } \\
\text { Landrill }\end{array}$ & $\begin{array}{l}\text { Class IV } \\
\text { Landfill }\end{array}$ & $\begin{array}{l}\text { Corrugated } \\
\text { Recycling } \\
\text { Processing }\end{array}$ & $\begin{array}{l}\text { Corruguted } \\
\text { Recycling } \\
\text { Collection }\end{array}$ & $\begin{array}{c}\text { Other } \\
\text { Recycling }\end{array}$ & $\begin{array}{c}\text { Composting } \\
\text { Facility }\end{array}$ & $\begin{array}{c}\text { Tire } \\
\text { Shredding }\end{array}$ & $\begin{array}{l}\text { Wood } \\
\text { Grinding }\end{array}$ & G\&A & Other & Total \\
\hline $\begin{array}{l}\text { SSWI Total } \\
\text { Operating } \\
\text { Expenses }\end{array}$ & 0 & $\$ 783,886$ & $\$ 98,323$ & $\$ 35,484$ & $\$ 39,716$ & $\$ 41,022$ & $\$ 967,307$ & $\$ 11,786$ & $\$ 13,460$ & $\$ 158,765$ & 0 & $\$ 2,149,749$ \\
\hline $\begin{array}{l}\text { SSWI Total } \\
\text { Annualized } \\
\text { Capital Costs }\end{array}$ & 0 & 270,558 & 84,349 & 36,652 & 19,096 & 0 & 776,570 & 4,687 & 21,141 & 66,257 & 22,670 & $1,301,980$ \\
\hline $\begin{array}{l}\text { Total Costs- } \\
\text { Sevierville } \\
\text { Collection }\end{array}$ & $\$ 318,422$ & 0 & 0 & 0 & 0 & 0 & 0 & 0 & 0 & 63,684 & 0 & 382,106 \\
\hline $\begin{array}{l}\text { Total Costs } \\
\text { Bag/Can } \\
\text { Containers } \\
\text { Costs }\end{array}$ & 95,038 & 0 & 0 & 0 & 0 & 0 & 0 & 0 & 0 & 0 & 0 & 95,038 \\
\hline $\begin{array}{l}\text { Total Gross } \\
\text { Cost }\end{array}$ & 413,460 & $1,054,444$ & 182,672 & 72,136 & 58,812 & 41,022 & $1,743,877$ & 16,473 & 34,601 & 288,706 & 22,670 & $3,928,873$ \\
\hline $\begin{array}{l}\text { Percent } \\
\text { "Applicable" } \\
\text { to MSW } \\
\text { Analyzed }\end{array}$ & $100 \%$ & $20.14 \%$ & $0 \%$ & $12.7 \%$ & $12.7 \%$ & $\mathbf{0}$ & $20.14 \%$ & 0 & 0 & $34.97 \%$ & 0 & - \\
\hline $\begin{array}{l}\text { Total } \\
\text { "Applicable" } \\
\text { Gross Cost for } \\
\text { MSW } \\
\text { Analyzed }\end{array}$ & $\$ 413,460$ & $\$ 212,365$ & 0 & $\$ 9,161$ & $\$ 7,469$ & 0 & $\$ 351,217$ & 0 & 0 & $\$ 100,971$ & 0 & $\$ 1,094,643$ \\
\hline
\end{tabular}


Table 9. Total Revenues of Sevierville's IMSWM System Allocated by Functional Area (FY 1993/1994 \$)

\begin{tabular}{|c|c|c|c|c|}
\hline Description & $\begin{array}{l}\text { Class IV Landfill } \\
\text { Disposal \& } \\
\text { Materials } \\
\text { Recovery }\end{array}$ & $\begin{array}{l}\text { Corrugated } \\
\text { Collection \& } \\
\text { Processing }\end{array}$ & $\begin{array}{l}\text { Composting } \\
\text { Facility }\end{array}$ & Total \\
\hline $\begin{array}{l}\text { SSWI Total Revenues } \\
\text { from Sale of Ferrous } \\
\text { Metals Recovered at } \\
\text { Class N Landfill }\end{array}$ & $\$ 2,844$ & NA & NA & $\$ 2,844$ \\
\hline $\begin{array}{l}\text { SSWI Total Revenues } \\
\text { from Sale of Ferrous } \\
\text { Metals Recovered at } \\
\text { Composting Facility }\end{array}$ & NA & NA & $\$ 6,300$ & 6,300 \\
\hline $\begin{array}{l}\text { SSWI Total Revenues } \\
\text { from Sale of Compost }\end{array}$ & NA & NA & 0 & 0 \\
\hline $\begin{array}{l}\text { SSWI Total Revenues } \\
\text { from Sale of Commercial } \\
\text { OCC }\end{array}$ & NA & $\$ 8,974$ & NA & 8,974 \\
\hline Total SSWI Revenues & $\$ 2,844$ & $\$ 8,974$ & $\$ 6,300$ & $\$ 18,118$ \\
\hline $\begin{array}{l}\text { Percent "Applicable" to } \\
\text { Analyzed MSW }\end{array}$ & $0 \%$ & $12.7 \%$ & $20.2 \%$ & $13.1 \%$ \\
\hline $\begin{array}{l}\text { Total "Applicable" } \\
\text { Revenues to Analyzed } \\
\text { MSW }\end{array}$ & 0 & $\$ 1,140$ & $\$ 1,270$ & $\$ 2,410$ \\
\hline
\end{tabular}

Table 10. Gross Costs of Managing Analyzed MSW by Functional Area (FY 1993/1994 \$)

\begin{tabular}{||lcrrc||}
\hline \multicolumn{1}{|c}{ Functional Area } & $\begin{array}{c}\text { Applicable Tons of } \\
\text { Analyzed MSW }\end{array}$ & \multicolumn{1}{c}{$\begin{array}{l}\text { Gross } \\
\text { Costs }\end{array}$} & \$/ton & $\begin{array}{c}\text { Percent of } \\
\text { Gross Costs }\end{array}$ \\
\hline Garbage Collection & & $\$ 413,460$ & $\$ 40.22$ & $38 \%$ \\
Composting Facility & 10,280 & 351,217 & 34.17 & $32 \%$ \\
Class I Landfill & & 212,365 & 20.66 & $19 \%$ \\
OCC Collection and & 31 & 16,630 & 536.45 & $2 \%$ \\
Processing & 10,311 & 100,971 & 9.79 & $9 \%$ \\
G\&A & $\mathbf{1 0 , 3 1 1}$ & $\mathbf{\$ 1 , 0 9 4 , 6 4 3}$ & $\$ 106.16$ & $\mathbf{1 0 0 \%}$ \\
\hline TOTAL & & & & \\
\hline
\end{tabular}


Table 11. Net Costs of Managing Analyzed MSW by Functional Area (FY 1993/1994 \$)

\begin{tabular}{||lcccc|}
\hline \multicolumn{1}{|c}{ Functional Area } & $\begin{array}{c}\text { Applicable Tons of } \\
\text { Analyzed MSW }\end{array}$ & Net Costs & $\$ /$ ton & $\begin{array}{c}\text { Percent of Net } \\
\text { Costs }\end{array}$ \\
\hline Garbage Collection & & $\$ 413,460$ & $\$ 40.22$ & $38 \%$ \\
Composting Facility & & 349,947 & 34.04 & $32 \%$ \\
Class I Landfill & $\$ 10,280$ & 212,365 & 20.66 & $19 \%$ \\
OCC Collection and & 31 & 15,490 & 499.68 & $1 \%$ \\
Processing & & & & \\
G\&A & 10,311 & 100,971 & 9.79 & $9 \%$ \\
\hline TOTAL & $\$ 10,311$ & $\$ 1,092,233$ & $\$ 105.93$ & $100 \%$ \\
\hline
\end{tabular}

\section{Allocation of Analyzed MSW Management Costs by Type of Waste}

The procedure to allocate the $\$ 1,094,643$ total gross cost of managing the 10,311 tons of analyzed MSW to the cost of managing garbage and OCC required only that general and administrative (G\&A) expenses be allocated in direct proportion to the allocation of other costs (except collection costs). Table 12 shows the results of this allocation.

Table 13 shows the results of the cost allocation after taking into account revenues that are attributable to analyzed MSW.

Table 12. Total Gross Costs of Sevierville's IMSWM System Allocated by Type of Waste (FY 1993/1994 \$)

\begin{tabular}{||lcrrr||}
\hline \multicolumn{1}{|c}{ Typo of Wasto } & $\begin{array}{c}\text { Total Grose Costs } \\
\text { (without G\&A) }\end{array}$ & Total G\&A & $\begin{array}{c}\text { Total Grose Costs } \\
\text { (with G\&A) }\end{array}$ & $\begin{array}{c}\text { Porcent of Groes } \\
\text { Costs (with G\&A) }\end{array}$ \\
\hline Garbage & & & & \\
Collection & $\$ 413,460$ & $\$ 63,684$ & $\$ 477,144$ & $44 \%$ \\
Class I Landfill & 212,365 & 13,648 & 226,013 & $21 \%$ \\
Composting Facility & 351,217 & 22,571 & 373,788 & $35 \%$ \\
Subtotal & 977,042 & 99,903 & $1,076,945$ & $100 \%$ \\
\hline Corrugated & & & & \\
Processing & 9,161 & 589 & 9,750 & $55 \%$ \\
Collection & 7,469 & 480 & 7,949 & $45 \%$ \\
Subtotal & 16,630 & 1,069 & 17,699 & $100 \%$ \\
\hline TOTAL & $\$ 993,672$ & $\$ 100,971$ & $\$ 1,094,643$ & NA \\
\hline
\end{tabular}


Table 13. Total Net Costs of Sevierville's City IMSWM System Allocated by Type of Waste (FY 1993/1994 \$)

\begin{tabular}{|c|c|c|c|c|c|c|c|}
\hline Type of Waste & $\begin{array}{c}\text { Total Gross } \\
\text { Costs (without } \\
\text { G\&A) }\end{array}$ & Total G\&A & $\begin{array}{l}\text { Total Gross Costs } \\
\text { (with G\&A) }\end{array}$ & Revenues & $\begin{array}{l}\text { Total Net } \\
\text { Costs (with } \\
\text { G\&A) }\end{array}$ & $\begin{array}{l}\text { Applicable } \\
\text { Tons of } \\
\text { Analyzed } \\
\text { MSW }\end{array}$ & $\begin{array}{l}\text { Net Costs } \\
\text { (with G\&A) } \\
\$ / \text { tons }\end{array}$ \\
\hline \multicolumn{8}{|l|}{ Garbage } \\
\hline Collection & $\$ 413,460$ & $\$ 63,684$ & $\$ 477,144$ & 0 & $\$ 477,144$ & \multirow{4}{*}{10,280} & $\$ 46.41$ \\
\hline Class I Landfill & 212,365 & 13,648 & 226,013 & 0 & 226,013 & & 21.99 \\
\hline Composting Facility & 351,217 & 22,571 & 373,788 & $\$ 1,270$ & 372,518 & & 36.24 \\
\hline Subtotal & $\$ 977,042$ & $\$ 99,903$ & $\$ 1,076,945$ & $\$ 1,270$ & $\$ 1,075,675$ & & $\$ 104.64$ \\
\hline \multicolumn{8}{|l|}{ Corrugated } \\
\hline $\begin{array}{l}\text { Collection and } \\
\text { Processing }\end{array}$ & 16,630 & 1,069 & 17,699 & 1,140 & 16,559 & 31 & 534.16 \\
\hline Total & $\$ 993,672$ & $\$ 100,972$ & $\$ 1,094,643$ & $\$ 2,410$ & $\$ 1,092,234$ & 10,311 & $\$ 105.93$ \\
\hline
\end{tabular}




\section{Program Incremental Costs}

A Program Incremental Cost (or Savings) is defined in these case studies as the difference between the cost of managing MSW with the inclusion of a particular program and the cost of managing MSW without that program.

The results of the Program Incremental Costs analysis are provided in Tables 14 and 15 . Each table shows in the first column the costs incurred by Sevierville in FY 1993/1994, which include the costs of both the OCC Recycling and Composting Facility Programs (i.e., "With Program"). The second column of each table (i.e., "Without Program") shows an estimate of the costs (or savings) that would have occurred if a given program had never been implemented. The difference between the first two columns is shown in the third column and represents the Program Incremental Cost (or Savings).

\section{Energy Usage Analysis}

The energy consumed to manage analyzed MSW is discussed in this section. The amount of energy consumed is estimated by category of analyzed MSW, type of energy consumed, and management program. Categories of analyzed MSW include garbage and recyclables (commercial OCC). Types of energy consumed include diesel fuel, gasoline, and electricity. Types of management programs include:

- Garbage and commercial OCC collection

- Recycling warehouse operation

- Composting facility operation

- Class I landfill operation

- Hauling commercial OCC and ferrous metals recovered at the composting facility to market.

Commercial OCC is hauled directly from the recycling warehouse to a remanufacturer. Estimated energy consumption for only the hauling is included in the analysis. Ferrous metals recovered at the composting facility is hauled to an intermediate location where it is processed before shipment to remanufacturers. The estimated energy consumption for transporting the ferrous metals to the intermediate processor is included, but energy consumption related to subsequent processing of the ferrous metals and transportation to the remanufacturer is excluded, due to insufficient data. The energy consumed in the remanufacturing process is also excluded because it is beyond the scope of the report.

In addition, energy consumption not directly related to Sevierville or SSWI solid waste management programs, such as electricity usage at Sevierville and SSWI offices, is not included in this analysis. 
Table 14. Incremental Cost of OCC Recovery Program (FY 1993/1994)

\begin{tabular}{||lccc||}
\hline \multicolumn{1}{|c}{ Cost Categories and Revenues } & $\begin{array}{c}\text { With } \\
\text { Program }\end{array}$ & $\begin{array}{c}\text { Without } \\
\text { Program }\end{array}$ & $\begin{array}{c}\text { Incremental Cost } \\
\text { (Savings) }\end{array}$ \\
\hline G\&A & $\$ 100,971$ & $\$ 100,971$ & 0 \\
OCC Collection & 7,469 & 0 & $\$ 7,469$ \\
Garbage Collection & 413,460 & 413,460 & 0 \\
OCC Processing & 9,161 & 0 & 9,161 \\
Class I Landfill & 212,365 & 212,446 & $(81)$ \\
Composting Facility & 351,217 & 351,885 & $(668)$ \\
Revenues & $(2,410)$ & $(1,270)$ & $(1,140)$ \\
\hline Total & $\$ 1,092,233$ & $\$ 1,077,492$ & $\$ 14,741$ \\
\hline Tons Managed & & & 31 \\
Incremental Cost Per Ton & & & $\$ 476$ \\
\hline
\end{tabular}

Table 15. Incremental Cost of the Composting Facility (FY 1993/1994)

\begin{tabular}{||lccc||}
\hline \multicolumn{1}{|c}{ Cost Categories and Revenues } & $\begin{array}{c}\text { With } \\
\text { Program }\end{array}$ & $\begin{array}{c}\text { Without } \\
\text { Program }\end{array}$ & $\begin{array}{c}\text { Incremental Cost } \\
\text { (Savings) }\end{array}$ \\
\hline G\&A & $\$ 100,971$ & $\$ 100,971$ & 0 \\
OCC Collection & 7,469 & 7,469 & 0 \\
Garbage Collection & 413,460 & 413,460 & 0 \\
OCC Processing & 9,161 & 9,161 & 0 \\
Class I Landfill & 212,365 & 350,632 & $(138,267)$ \\
Composting Facility & 351,217 & 0 & 351,217 \\
Revenues & $(2,410)$ & $(1,140)$ & $(1,270)$ \\
\hline Total & $\$ 1,092,233$ & $\$ \mathbf{8 8 0 , 5 5 3}$ & $\$ \mathbf{2 1 1 , 6 8 0}$ \\
\hline Tons Managed & & & 10,280 \\
Incremental Cost Per Ton & & & $\$ 21$ \\
\hline
\end{tabular}




\section{Collection Vehicles}

Sevierville uses six vehicles to collect residential and commercial garbage. The type, year, and capacity of these vehicles are shown in Table 16.

Table 16. Sevierville Garbage Collection Vehicles

\begin{tabular}{||lll||}
\hline \multicolumn{1}{|c}{ Type } & Year & Capacity (cubic yards) \\
\hline Residential and Small Commercial Accounts & & \\
Rear-Loader & 1983 & 20 \\
Rear-Loader & 1988 & 25 \\
Rear-Loader & 1991 & 25 \\
Large Commercial (Dumpster) Accounts & & \\
Front-Loader & 1987 & 38 \\
Front-Loader & 1989 & 33 \\
Front-Loader & 1992 & 38 \\
\hline
\end{tabular}

Major pieces of SSWI diesel equipment used at the recycling warehouse and Class I and IV landfills and the estimated percent of total diesel used are shown in Table 17.

Table 17. SsWI Diesel Equipment

\begin{tabular}{|lcc||}
\hline \multicolumn{1}{|c}{ Type } & Year & $\begin{array}{c}\text { Estimated Percent of } \\
\text { Diesel Usage }\end{array}$ \\
\hline Recycling Warehouse & & $15 \%$ \\
Forklift (Make/Model Unknown) & 1992 & \\
Mack Side-Loading Truck & 1993 & \\
Class I Landfill & & $63 \%$ \\
John Deer 762 B Pan Scraper & 1990 & \\
Revworks 3-55B Compactor & 1994 & \\
Dresser TD15E Dozer & 1990 & \\
Class IV Demolition Landrill & & \\
Front-End Loader (Make/Model Unknown) & 1990 \\
Tub Grinder (Make/Model Unknown) & 1992 \\
Al Jon Tire Shredder & 1991 & \\
\hline
\end{tabular}


Table 18 presents a summary of the estimated energy consumed for collecting analyzed MSW (garbage and commercial OCC) from Sevierville.

Table 18. Energy Consumed to Collect Analyzed MSW in Sevierville (FY 1993/1994)

\begin{tabular}{|lcc|}
\hline & Garbage & Commercial OCC \\
\hline Analyzed MSW (tons) $^{\mathrm{a}}$ & 10,280 & 31 \\
Diesel Fuel Consumed (gallons) $^{\mathrm{b}}$ & 18,000 & 230 \\
Gallons Per Ton & 1.75 & 7.4 \\
\hline
\end{tabular}

Notes:

analyzed MSW is defined and associated quantities are presented in Table 4.

${ }^{b}$ Diesel fuel consumed by collecting garbage was estimated based on data provided by Sevierville on total expenditures for diesel fuel by the Sanitation Department and approximate cost per gallon of diesel fuel. Fuel consumed to collect OCC is estimated by first using limited SSWI data to estimate the gallons per ton used on a county-wide basis to collect OCC and then multiplying by the estimated quantity of OCC collected in Sevierville during FY 1993/1994.

\section{Recycling Warehouse}

The two types of energy used at the recycling warehouse are electricity for the baler, lighting, and auxiliaries; and diesel fuel for the fork lift.

\section{Composting Facility}

Energy in the forms of electricity, diesel fuel, and gasoline are consumed at the composting facility. Mobile equipment used at the composting facility during FY 1993/1994 are shown in Table 19.

Table 19. Mobile Equipment Used at a Composting Facility

\begin{tabular}{||llcc||}
\hline \multicolumn{1}{|c}{ Model } & Description & Year & Fuel Type \\
\hline CAT 936 & Front-End Loader & 1992 & Diesel \\
CAT 926 & Front-End Loader & 1992 & Diesel \\
MI 843 & Skid Steer Loader & 1992 & Diesel \\
Mack & Tractor & 1973, & Diesel \\
& & refurbished and rebuilt in & \\
& & 1992 & Gasoline \\
\hline
\end{tabular}

\section{Class I Landfill}

Diesel fuel is the only type of energy consumed at the Class I landfill. Landfill equipment using this fuel include a pan scraper, a compactor, and a dozer. 


\section{Hauling Recovered Materials to Market}

The commercial OCC collected by SSWI is baled and then transported by tractor-trailer to an end user in Chattanooga, Tennessee, approximately 130 miles away.

Ferrous metals recovered at the compost facility is hauled by tractor-trailer to an intermediate processor in Rockwood, Tennessee, approximately 80 miles.

Bedminster does not have established markets for its compost product. Both local and distant outlets were used during FY 1993/1994. Most of the distant outlets were testing sites where the compost was sent for evaluation. Shipping compost over such long distances is expected to significantly diminish in the future. Therefore, to prevent the temporary shipment of compost over long distances from skewing the energy consumption data, it was assumed that all compost was distributed at an average distance of 10 one-way miles from the facility during FY 1993/1994 via dump truck using diesel fuel.

\section{Total Energy Consumption}

Based on the analysis discussed above, the total energy consumption during FY 1993/1994 related to managing analyzed MSW by type of energy was calculated. The results are shown in Table 20. Also, the total energy consumption in Btu was determined based on the following conversion factors, which are consistent with factors used in the other case studies:

- Diesel Fuel: 146,390 Btu/gallon

- Gasoline: 127,650 Btu/gallon

- Electricity: 3,413 Btu/kWh

The estimated total energy consumed during FY 1993/1994 for managing analyzed MSW is 6910 million Btu or 0.7 million Btu per ton managed. The energy consumption in Btu can be broken down by type of activity as follows:

- Collection: $39 \%$

- Facilities: 59\%

- Hauling: $2 \%$ 
Table 20. Total Energy Consumption for Managing Analyzed MSW (FY 1993/1994)

\begin{tabular}{|lcccc||}
\hline \multicolumn{1}{|c}{ Activity } & $\begin{array}{c}\text { Diesel Fuel } \\
\text { (gallons) }\end{array}$ & $\begin{array}{c}\text { Gasoline } \\
\text { (gallons) }\end{array}$ & $\begin{array}{c}\text { Electricity } \\
\text { (MWh) }\end{array}$ & $\begin{array}{c}\text { Total Energy } \\
\text { (millions of } \\
\text { Btu) }\end{array}$ \\
\hline Collection Vehicles & & & & \\
Garbage & 18,010 & NA & NA & 2,640 \\
Corrugated & 230 & NA & NA & 30 \\
$\quad$ Subtotal & 18,240 & NA & NA & 2,670 \\
Facilities & & & & \\
Recycling Warehouse & 35 & NA & 5 & 20 \\
Composting Facility & 3,280 & 80 & 970 & 3,800 \\
Class I Landfill & 1,810 & NA & NA & 260 \\
Subtotal & 5,125 & 80 & 975 & 4,080 \\
Haul to Markets & & & & 120 \\
Compost & & NA & NA & 10 \\
Corrugated & 790 & NA & NA & 30 \\
Ferrous Metals & 90 & NA & NA & 160 \\
Subtotal & 180 & NA & NA & 6,910 \\
TOTAL & 1,060 & 80 & 975 & \\
\hline
\end{tabular}

Notes

'Based on assumptions used in other case studies, energy content of diesel fuel assumed to be $146,390 \mathrm{Btw} / \mathrm{gallon}$ and energy content of gasoline assumed to be $127,650 \mathrm{Btw} / \mathrm{gallon}$. Electricity usage converted to Bul assuming $3413 \mathrm{Btw} / \mathrm{kWh}$. Diesel fuel usage for collection vehicles taken from Table 17.

${ }^{b}$ Includes energy consumed to haul materials to first destination after leaving SSWI site. For compost and OCC, the first destination is the end user/remanufacturer. This destination for ferrous metals is an intermediate processor.

Data on energy consumption at the intermediate processing facility and energy consumed while hauling the ferrous metals to a remanufacturer were not available.

\section{Equivalent Energy Consumption}

The energy consumption for managing each category of Analyzed Waste is shown in Table 21 on the basis of equivalent gallons of diesel consumed. These amounts were calculated by converting the total Btu energy consumption figures in Table 20 into equivalent gallons of diesel, assuming that diesel has an energy content of 146,390 Btu per gallon. 
Table 21. Equivalent Per Gallon Energy Consumption for Managing Analyzed MSW

(FY 1993/1994 Equivalent Diesel Gallons Per Ton)

\begin{tabular}{|lccc||}
\hline & \multicolumn{3}{c|}{ Equivalent Diesel Gallons Per Ton } \\
\cline { 2 - 4 } \multicolumn{1}{r}{ Activity } & Garbage & $\begin{array}{c}\text { Commercial } \\
\text { Corrugated }\end{array}$ & $\begin{array}{c}\text { Total Analyzed } \\
\text { MSW }\end{array}$ \\
\hline Collection Vehicles & & & \\
Garbage & 1.75 & NA & 1.75 \\
Corrugated & NA & 7.38 & 0.02 \\
Subtotal & 1.75 & 7.38 & 1.77 \\
Facilities & & & \\
Recycling Warehouse & NA & 4.41 & 0.01 \\
Composting Facility & 2.53 & NA & 2.52 \\
Class I Landfill & 0.17 & NA & 0.17 \\
Subtotal & 2.70 & 4.41 & 2.70 \\
Haul to Markets & & & \\
Compost & & NA & 0.08 \\
Corrugated & 0.08 & 2.20 & 0.01 \\
Ferrous Metals & NA & NA & 0.02 \\
Subtotal & 0.02 & 2.20 & 0.11 \\
\hline TOTAL & 0.10 & 13.99 & 4.58 \\
\hline
\end{tabular}

\footnotetext{
Notes:

${ }^{4}$ Based on assumptions used in other case studies, energy content of diesel fuel assumed to be $146.390 \mathrm{Btw} / \mathrm{gallon}$.

Total Bu taken from Table 20. Quantity of garbage in analyzed MSW is 10,280 tons. Quantity of commercial OCC in analyzed MSW is 31 cons.

bIncludes energy consumed to haul materials to first destination after leaving SSWI site. For compost and OCC, the first destination is the end usethemanufacturer. This destination for ferrous metals is an intermediate processor. Data on energy consumption at the intermediate processing facility and energy consumed while havling the ferrous metals to a remanufacturer were not available.
}

\section{Environmental Regulations and Permitting Requirements}

The costs of compliance with the environmental and safety regulations and permit requirements discussed in this section are reflected in the costs reported previously. 


\section{Overview of Relevant Federal Environmental Legislation and Regulations}

The potential environmental impacts of solid waste management facilities have led to the development of an extensive network of federal and state regulations with the states carrying out the day-to-day activities of implementation and enforcement.

The Clean Air Act, most recently amended in 1990, established programs for protecting public health and the environment from exposure to gaseous emissions, including toxic air pollutants. ${ }^{1}$ The Clean Water Act, most recently amended in 1987, is the principal federal law protecting the nation's waterways from pollution. ${ }^{2}$ The Safe Drinking Water Act, most recently amended in 1988, established programs for protecting public drinking water systems from harmful contaminants. ${ }^{3}$ Finally, the Solid Waste Disposal Act and Resource Conservation and Recovery Act (RCRA) of 1976, most recently amended in 1992, and currently undergoing Congressional review for reauthorization, is the main piece of federal legislation addressing landfill disposal regulation. ${ }^{4}$

Because the county's IMSWM system does not include solid waste combustion, the Clean Air Act does not apply to the facilities comprising the IMSWM system. However, proposed changes to the Clean Air Act may apply to the IMSWM system by requiring the installation of an active gas system at MSW landfills.

Pursuant to the Clean Water Act, a solid waste management facility cannot cause a discharge of pollutants that is in violation of the requirements of the National Pollutant Discharge Elimination System (NPDES) into United States waters. The NPDES permit requires the source to attain technology-based effluent limits, using "best practicable control technology" and "best available technology."

A separate permit is required to dispose of dredge or fill material into waterways, including wetlands. Other regulations promulgated under the Clean Water Act include guidelines for using and disposing of sewage sludge (addressed later in the composting facility subsection).

Pursuant to the Safe Drinking Water Act, a facility or practice cannot contaminate an underground drinking water source beyond the solid waste management boundary or beyond an alternate boundary.

Pursuant to RCRA, criteria were established to determine which solid waste disposal facilities and practices pose a reasonable probability of adverse effects on public health or the environment ${ }^{5}$ The objective of these criteria is to mitigate adverse effects through the protection of floodplains, endangered species, surface water, and groundwater. These criteria also provide guidelines for sludge use and disposal under the Clean Water Act.

\footnotetext{
IThe Clean Air Act and Major Amendments are codified as 42 U.S.C. 7401-7671, 1990.

${ }^{2}$ The Clean Water Act and Major Amendments are codified as 33 U.S.C. 1251-1387, 1987.

${ }^{3}$ The Safe Drinking Water Act and Amendments are codified as 42 U.S.C. 300f-300j-11, 1988.

The Solid Waste Disposal/Resource Conservation and Recovery Act and Major Amendments are codified as 42 U.S.C. $6901-6991 \mathrm{k}, 1992$.

$5_{40}$ CFR, EPA. Part 257-Criteria For Classification of Solid Waste Disposal Facilities and Practices.
} 
Subtitle D of RCRA primarily addresses nonhazardous waste, whereas Subtitle C of RCRA addresses hazardous waste disposal. In October 1991, the Environmental Protection Agency promulgated revised Subtitle D regulations applicable to municipal solid waste landfills, with an effective date of October 1993. In general, the new regulations require liners, leachate collection, groundwater monitoring, and corrective action at municipal landfills.

\section{Overview of State and Local Environmental Regulations}

Municipal solid waste management is regulated in accordance with Tennessee's Solid Waste Management Act of 1991 (T.C.A. 68-211-813(c) and 68-211-815). The act was also amended in 1992 (Chapters 693, 759.d). The law is administered by the Tennessee Department of Health and Conservation (TDEC) Solid Waste Management Division. The act designated the formation of municipal solid waste "regions," which, in the case of this study, include the county and its four municipalities. Each region was to have submitted a plan to the state's Solid Waste Assistance Program for review. The Sevier Solid Waste Regional Board submitted its plan in July 1994.

The state has adopted solid waste storage, processing and disposal regulations, and performance standards for landfills consistent with the federal Subtitle D regulations. Requirements for leachate and gas mitigation and control will be effective in October 1996.

There are also specific restrictions on the disposal of special wastes (including sludges, bulky waste, pesticides, and industrial/hazardous waste), tires, medical waste, and dead animals. To address issues involving these types of waste materials, the county implemented a tire shredding and stockpiling area, a wood waste grinding operation, a wood pallet reuse program, and a ferrous metals recovery program at the Class IV demolition landfill, and an MSW/sewage sludge co-composting facility (operated by Bedminster).

\section{Composting Facility}

Composting facility regulations and end product standards are currently being developed for the state of Tennessee. Thus, no composting regulations were in place for the state of Tennessee at the time of the signing of the contract between Bedminster and SSWI. In lieu of a formal permit, the TDEC sent the facility a set of minimum standards under which the facility was granted "permit by rule" status.

One recurring problem has been with seepage underneath one of the biofilters. Excess leachate continued to be observed from the biofilters as recently as early November 1994. Bedminster reports that a wet well will be instailed to recirculate percolate through the biofilters.

${ }^{6}$ On October 1, 1993, the federal criteria for MSW landfills under subtitle D of RCRA were amended to extend the date of compliance for small landfills to April 9, 1994, and by delaying the effective date of subpart G, Financial Assurance, to April 9 , 1995, for all MSW landfills. In addition, the MSW landfill criteria were amended by removing the exemption from the groundwater monitoring requirements and by delaying the date for compliance with all requirements of the MSW landfill criteria for 2 years for owners and operators of MSW landfill units in arid and remote areas that meet the qualifications of the small landfill exception in the MSW landfill criteria. (Federal Register, "Solid Waste Disposal Facility Criteria; Delay of Compliance and Effective Dates," Vol. 58. No. 189, pages 51536-51548, 1993.) 
Because the facility processes sludge in addition to MSW, the facility is bound to conform to standards for the final use or disposal of sewage sludge, per Section 503 of the Clean Water Act. According to the rule, the finished product is considered "exceptional quality" and allowed unlimited distribution if certain criteria are met. The Bedminster composting facility's operation plan and end product laboratory results indicate that Bedminster's product conforms to the standards for exceptional quality.

Odor complaints have been received at the facility. Specifically, approximately 15 to 20 calls regarding odor were received by Bedminster during the period from September 1992 to early January 1993. This high volume of odor complaints was attributed to the facility operating before construction was complete. A significant reduction in telephone calls regarding odors was noted after the completion of the enclosure of the curing building and the biofilter system. Bedminster usually has the capability to thwart potential odor problems using its centralized computer control system to detect mechanical malfunctions and automatically dial the telephone number of an on-call plant operator.

The Tennessee Solid Waste Disposal Act states that it is unlawful to construct or operate a solid waste facility that creates a public nuisance. However, the word "nuisance" is not defined in the law, and the solid waste regulations that resulted from the Tennessee Solid Waste Disposal Act contain no mention of odor. As a result, the TDEC cannot cite "odor violations" during monthly inspections of solid waste facilities. The TDEC will gain more direct control over citing violations and issuing penalties to composting facilities when the composting regulations currently being drafted become law.

\section{Processing Facility}

Key processing facilities operated by SSWI include a recycling warehouse for storage and baling of OCC and a wood chipping operation designed to produce mulch products for residential use. Like the composting facility, processing facilities are regulated under the "permit-by-rule" program administered by the TDEC Solid Waste Management Division. A review of TDEC files indicated that the wood chipping operation has been notified of storage and drainage problems.

\section{Landfills}

\section{Class I Landfill}

The permit for SSWI's currently operating Class I landfill was issued in June 1993 by the TDEC. Closed portions of the landfill were cited beginning in 1991 for violations of closure and post-closure standards for monitoring erosion control and leachate control. Due to ongoing non-compliance by SSWI, fines in excess of $\$ 20,000$ were assessed to SSWI in July 1993. Continued problems related to the original notice of violation were identified during an inspection of inactive landfill areas in mid-1994. Corrective actions appear to have been taken, with no apparent enforcement taken by TDEC.

In accordance with TDEC regulations, the landfill must be operated to meet the minimum concentration values for groundwater protection. Inspection of the Class I landfill (Phase A) by the TDEC found that garbage was placed against sideslope liners rather than placing a protection layer of soil between the first lift of waste and the landfill liner. Inspection reports also indicated that additional litter control was necessary, the working face of the landfill was too large, and leachate had been observed in surface water control features. 
A 5-foot-thick geologic buffer with a maximum permeability of $1 \times 10^{-5} \mathrm{~cm} / \mathrm{sec}$ (or an equivalent or superior buffer) between the base of the landfilled material and the high water table is required at a Class IV landfill. Leachate collection and gas migration controls are not required at a Class IV disposal facility. Cover is to be placed on Class IV waste at least every 30 days. Class IV disposal facilities are typically exempt from having to implement a groundwater monitoring system. Waste tire handling and disposal practices in the county meet state guidelines with a permitted tire storage area at the demolition landfill. Review of TDEC site inspection reports indicated that violations related to the landfilling of unacceptable materials-including compost and MSW, along with demolition waste-have been noted and corrected.

\section{Class IV Landfill Special Wastes}

Lead acid batteries and waste oil are deemed unacceptable for disposal at either the Class I or Class IV landfills. Presentiy, waste oil is collected at several locations and recycled. Lead acid batteries are collected and recycled by local automotive service centers in the region. In 1993, the TDEC developed requirements for temporary locations within counties for the collection, sorting, and packaging of HHW. In keeping with the state's "1993 Policy Guide on County Responsibilities for the Tennessee HHW Collection Program," the county selected the Class IV demolition landfill as a temporary HHW collection site. Implementation of the HHW program is expected to occur in 1995.

\section{Overview of Occupational Health and Safety Regulations}

\section{Federal Regulations}

The Occupational Safety and Health Act of $1970^{7}$ imposes two basic duties on private employers:

(1) To comply with occupational safety and health standards developed by the Occupational Safety and Health Administration (OSHA) pursuant to the Occupational Safety and Health Act

(2) To comply with the General Duty Clause, Section 5(a)(1), which requires that employers protect their employees from recognized hazards not regulated by an OSHA standard.

Periodic inspections, either routine or in response to complaints, are conducted

by OSHA to ensure that specific applicable standards are being met and that the workplace is generally free from recognized hazards likely to cause serious injury or death. When OSHA compliance officers discover areas of noncompliance resulting in hazards, employers may be issued citations, and penalties and abatement periods may be proposed.

\footnotetext{
7Occupational Safety and Health Act of 1970, 5 USC 5108, 1970, most recently amended October 1992.
} 
OSHA provisions do not apply to state and local governments in their role as employers. The Act does provide that any state desiring to gain OSHA approval for its private sector occupational safety and health program must provide a program that covers its state and local government workers and that is at least as effective as its program for private employees. State plans may also cover only public sector employees. The state of Tennessee has an OSHA-approved state plan. The plan, with a few minor exceptions, is consistent with federal OSHA regulations and is administered through the Tennessee Department of Labor.

Private employers are required to comply with the General Industry Standards included in the Tennessee Occupational Safety and Health Plan. Thus, the SSWI-owned, but privately operated, compost facility must comply. 


\section{Appendix A - References}

Association County Commissioners of Georgia, "Waste + Composting = Topsoil", Georgia County Government, October 1993.

Bedminster, "Compost Quality Documentation."

Bedminster, "OrganagrOß Compost Information."

Bedminster, "Fact Sheet - Sevier Solid Waste Composting Facility."

Bedminster, "Sevier, Tennessee Facility Waste/Residue/Electricity Comparison", Fax from T.J. Williams to Alan Cohen, October 14, 1994.

Bedminster, "Bedminster Bioconversion Corporation Operating Cost for the Fiscal Year Ending June 30, 1994" and "Bedminster Bioconversion Corporation Weight Summary for the Fiscal Year Ending June 30, 1994", Fax from T.J. Williams to Dan Cearley, November 30, 1994.

Bedminster, Fax from T. J. Williams to Dan Cearley containing list of composting facility equipment, November 23, 1994.

Bedminster, Summary of compost shipments for January through June, 1994.

Bedminster, "A Citizen's Guide to the Sevier County Composting Plant".

Bedminster, "Haulers."

Bedminster, "1993 Tennessee Compost Shipments".

Bedminster, "Solid Waste Composting Council, Compost Facility Operating Guide, Operating Facility Site Visit Pre-Visit, Information Request", Fax from Ken Aiani to Steve Jones, June 9, 1993.

Bureau of Economic Analysis, Local Planning Assistance, Department of Economic and Community Development, "Population Projection, 1990-2000 for Sevier County".

Case Study: Scottsdale, Arizona Integrated Municipal Solid Waste Management System, prepared for the Solid Waste Association of North America, prepared by CSI Resource Systems, Inc., August 1994.

Case Study: Springfield, Massachusetts Integrated Municipal Solid Waste Management System, prepared for the Solid Waste Association of North America, prepared by CSI Resource Systems, Inc., July 1994.

Case Study: Palm Beach County, Florida Integrated Municipal Solid Waste Management System, prepared for the Solid Waste Association of North America, prepared by CSI Resource Systems, Inc., June 1994. 
Case Study: Seattle, Washington Integrated Municipal Solid Waste Management System, prepared for the Solid Waste Association of North America, prepared by CSI Resource Systems, Inc., January 1994.

Charter of Sevier Solid Waste, Inc., December 7, 1988.

Cohen, Alan, Notes containing information gathered from SSWI and the City of Sevierville.

East Tennessee Development District, "Housing Units, Households and Population Per Household", March 1991.

East Tennessee Development District, "Tennessee Community Data Sevierville, Tennessee."

East Tennessee Development District, "Sevier County Economic Statistics, Summer, 1994."

The Fact Book of the Great Smokies, Edited by Delman D. Dennis, Nandel Publishing Company, Copyright 1994.

Goldstein, Nora, "Cocomposting in Tennessee," BioCycle, November 1993.

Hancock, Chandler, Letter from Hancock Horticultural Services to Ms. Rebecca Roe of Bedminster of Tennessee, Inc., January 27, 1994.

Hickman and Company, P.C., "Sevier Solid Waste, Inc. Financial Statements," June 30, 1993 and 1992.

Hickman and Company, P.C., "Sevier Solid Waste, Inc. Financial Statements," June 30, 1994 and 1993.

Hickman and Company, P.C., Miscellaneous trial balance worksheets for Sevier Solid Waste, Inc. Financial Statement for Fiscal Year 1993/94.

Hiscock, Ed, "Meeting the MSW Composting Challenge," Solid Waste Technologies, Industry Sourcebook 1994.

Local Planning Assistance Office, Sevier County Solid Waste Plan, Department of Economic and Community Development, Knoxville, Tennessee, October 1990.

Sevier County, "Blue Book," A Directory of Sevier County Organizations \& Services, 1994-95.

City of Sevierville, Solid waste ordinances.

City of Sevierville, "Annual Budget," Fiscal Year 1994-1995.

City of Sevierville, "Trucks, City of Sevierville" and "Gas Billings Street and Sanitation Department."

City of Sevierville, "Sevierville Citizen", October 1994. 
SSWI, "Yearly Waste Report - January 1, 1993 through December 31, 1993," Computer Printout, January 3, 1994.

"Solid Waste Facilities Construction and Operating Agreement between Sevier Solid Waste Inc. and Bedminster Bioconversion Corporation," September 19, 1991.

SSWI, "Yearly Waste Report - July 1, 1993 through June 30, 1994," Computer Printout, June 30, 1994.

SSWI, "Sevier County Solid Waste Regional Plan," Sevier Solid Waste Regional Board, July 1, 1994.

SSWI, "Summary of Assets - Accumulated Depreciation," June 30, 1994.

SSWI, "Amortization Expenses, FY 93-94."

SSWI, Equipment depreciation schedules.

[Source Unknown] Appendix C, Illustrative Calculation of Estimated Total Current Cost of MSWLF Closure and Postclosure Care and Current-Period Expenses and Liabilities Amounts.

[Source Unknown], Sevier Solid Waste Composting Facility flow diagram.

Tennessee Department of Conservation, files on SSWI facilities.

U. S. Department of Commerce, Bureau of the Census, 1990 Census of Populaton and Housing. Waters, Larry, "Waste Not, Want Not", American City \& County, June 1993. 


\section{Appendix B - Glossary of Terms}

ALLOCATED COST (\$/year):

ANALYZED MSW:

AVERAGE COST

AVERAGE PROGRAM INCREMENTAL COST (SAVINGS) (\$/ton):

BULKY WASTE:

COMMERCIAL MSW:

GARBAGE:
That portion of the Total Cost that is expended or apportioned to a specific activity such as the management of garbage, trash, recyclables, yard waste, or household hazardous waste.

Portion of the MSW stream for which the cost of collecting, transferring, hauling, processing, combusting, marketing, and/or disposing of such waste is known or can be reasonably estimated.

(\$/ton):Total or Allocated Cost divided by the tons of MSW, garbage, trash, recyclables, or yard waste, as appropriate.

The Program Incremental Cost divided by the number of tons of materials diverted from the landfill by the program.

Oversized items, including white goods and furniture, that have been separated from the MSW stream for separate collection.

Municipal solid waste that is generated by sources other than households, including businesses (e.g., offices, restaurants, retail stores, and industry); institutions (e.g., schools and government establishments); and public areas (e.g., train stations, airports, and litter from roadside).

Garbage is all MSW exclusive of sourceseparated trash, recyclables, yard waste, household hazardous waste, and bulky waste. 
HAZARDOUS WASTE:

HOUSEHOLD HAZARDOUS WASTES (HIHW):

INTEGRATED SOLID WASTE MANAGEMENT:

MARGINAL COST (SAVINGS) (\$/ton):

MARGINAL COST (SAVINGS) OF SUBSTITUTION (\$/ton):

MATERIALS RECOVERY:

MUNICIPAL SOLID WASTE (MSW):
Waste which because of its quantity, concentration, or physical, chemical, or infectious characteristics, may pose a substantial present or potential hazard to human health or the environment when improperly treated, stored, transported, disposed of, or otherwise managed and is defined as such in accordance with federal and State laws. Does not include Household Hazardous Waste.

Materials that are separated from Residential MSW as household hazardous wastes for separate collection and treatment. Such materials may include paints and solvents, pesticides, herbicides, and propane tanks.

A practice of using several (i.e., two or more) alternative waste management techniques to treat, process, and/or dispose of the Municipal Solid Waste stream. Alternative waste management techniques include source reduction, recycling, composting, combusting, and landfilling.

The cost (savings) of managing an additional ton of MSW, garbage, trash, recyclables, or yard waste.

The net cost (savings) of managing an additional ton of recyclables or yard waste less the savings (cost) of managing one less ton of garbage.

A term describing the extraction and utilization of materials from a waste stream.

Non-hazardous solid wastes generated by households, commercial and business establishments, institutions, and light industry; it excludes industrial process wastes, agricultural wastes, mining wastes, 
construction and demolition debris, offal, sludges, and ashes, except ashes derived from the combustion of MSW. In practice, specific definitions vary across jurisdictions.

PROGRAM INCREMENTAL COST (SAVINGS) (\$/year):

RECOVERED MATERIALS:

RECYCLABLE MATERIALS OR RECYCLABLES:

RECYCLE:

RESIDENTIAL MSW:

RESIDUE:

RESOURCE RECOVERY:
The difference between the cost of managing MSW with or without a particular program (e.g., curbside collection, processing, and marketing of recyclables.)

Recyclable materials that are recovered from MSW and may also include some contamination.

Materials that still have useful physical or chemical properties after serving their usefulness for a given individual or firm and can, therefore, be reused or recycled for the same or other purposes.

To convert discarded materials into useful products through reuse and remanufacturing.

Municipal solid waste that is generated by households.

That portion of processed MSW that is ultimately disposed of in a landfill.

A term describing the extraction and utilization of energy or materials from a waste stream.

A material that is used in place of a primary or raw material in manufacturing a product; often handled by dealers and brokers in "secondary markets." 
The delivery of MSW or other wastes to an integrated municipal solid waste management system by a private firm or individual that is not under contract to a municipality, authority, utility, or other public entity responsible for municipal solid waste management to make such deliveries.

TOTAL NET COST OR TOTAL COST (\$/year):

YARD WASTE:

WHITE GOODS:
The aggregate of all expenditures incurred to manage municipal solid waste, inclusive of general and administrative, planning, capital, collection, processing, transfer and haul, marketing, promotion and education, and disposal costs, less any revenues derived from resource recovery activities.

Vegetative material that is segregated from the MSW stream for separate collection and/or processing, including grass, prunings, plants, and small tree limbs, but excluding tree stumps, land-clearing debris, and other large vegetative matter (see Brush).

That portion of bulky waste which consists of large appliances, such as refrigerators, stoves, washing machines, and dryers. 


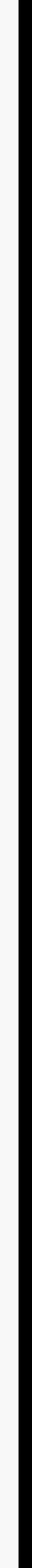




\section{Contents}

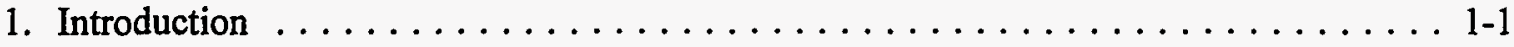

$1.1 \quad$ Sevier County . . . . . . . . . . . . . . . . . . 1-1

1.2 City of Sevierville . . . . . . . . . . . . . . . . . 1-4

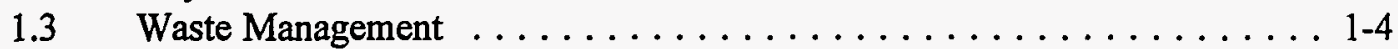

2. Municipal Solid Waste Management System $\ldots \ldots \ldots \ldots \ldots \ldots \ldots \ldots \ldots$ 2-1

2.1 Sevier Solid Waste, Inc. . . . . . . . . . . . . . . 2-1

2.2 System Overview . . . . . . . . . . . . . . . . . 2-1

2.3 System Component Descriptions .................. 2-2

2.3.1 Garbage and Demolition Waste Collection . . . . . . . . . 2-2

2.3.2 Commercial Corrugated Collection and Processing ...... . . 2-5

2.3.3 Drop-Off Recyclables Collection . . . . . . . . . . . 2-5

2.3.4 Drop-Off Used Motor Oil Collection . . . . . . . . . . . . . . 2-6

2.3.5 Sevier Solid Waste Composting Facility . . . . . . . . . . . 2 2-6

2.3.6 Class I Landfills . . . . . . . . . . . . . . . . . . . . 2-10

2.3.7 Class IV Landfill ... . . . . . . . . . . . . . . . . 2-11

2.3.8 Public Information and Education Programs . . . . . . . . 2-12

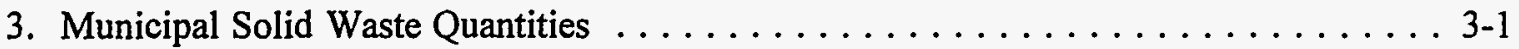

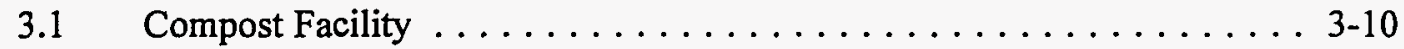

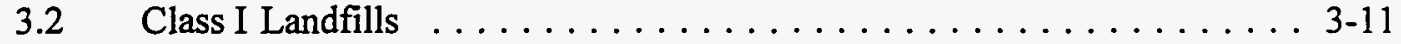

3.3 Class IV Landfill ......................... 3-11

3.4 Recyclables Drop-Off and Commercial Corrugated Programs . . . . . 3-12

3.5 HHW (Used Motor Oil) Program . . . . . . . . . . . . . . . . 3-13

3.6 Recovered Materials and Compost Markets . . . . . . . . . . . . 3-13

4. Cost of Municipal Solid Waste Management ... . . . . . . . . . . . 4-1

4.1 Apportionment of Waste Stream . . . . . . . . . . . . 4-1

4.2 Total Costs of Waste Management . . . . . . . . . . . . . . . 4-2

4.2.1 SSWI Reported and Adjusted Costs ... . . . . . . . . 4-3

4.2 .2 City Reported Costs . . . . . . . . . . . . . . 4-5

4.2.3 Costs of Bags, Cans, and Containers . . . . . . . . . 4-6

4.2.4 Combined Costs and Revenues . . . . . . . . . . . . . 4-6

4.3 Total Costs of Analyzed MSW Management and Costs by

Functional Area ................... 4-7

4.4 Allocation of Analyzed MSW Management Costs by

Type of Waste ................... 4-10

4.5 Program Incremental Costs . . . . . . . . . . . . . . 4-11

4.5.1 OCC Recycling Program . . . . . . . . . . . . . 4-11

4.5.2 Composting Facility Program . . . . . . . . . . . . 4 4-11

4.6 Summary of Results . . . . . . . . . . . . . . . . . . . 4-14 


\section{Contents (Continued)}

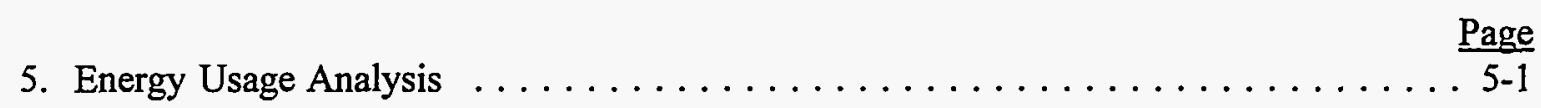

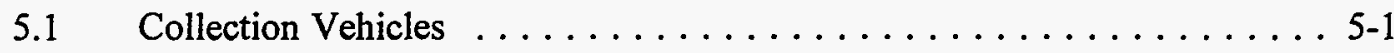

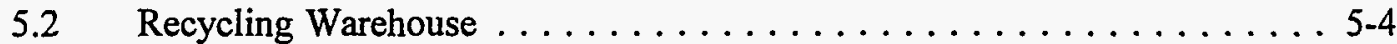

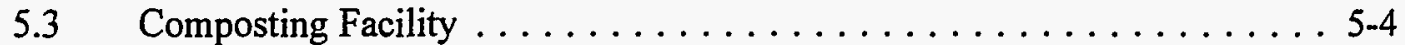

5.4 Class I Landfill . . . . . . . . . . . . . . . . . . 5-5

5.5 Hauling Recovered Materials to Market . . . . . . . . . . . 5-6

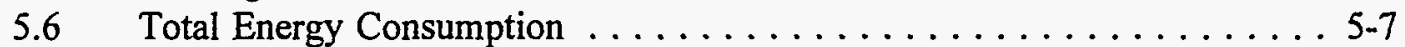

5.7 Equivalent Energy Consumption $\ldots \ldots \ldots \ldots \ldots \ldots \ldots \ldots \ldots$

6. Environmental Regulations and Permitting Requirements $\ldots \ldots \ldots \ldots \ldots \ldots$.

6.1 Overview of Relevant Federal Environmental

Legislation and Regulations ............... 6-1

6.2 Overview of State and Local Environmental

Regulations ....................6.3

6.2.1 Permit Requirements for Each IMSWMS Facility . . . . . . . . 6-5

6.2.1.1 Composting Facility . . . . . . . . . . . 6-5

Odor Complaints . . . . . . . . . . . 6-6

Regulatory Authority Concerning Odor at Tennessee

Composting Facilities . . . . . . . . . 6-6

6.2.1.2 Processing Facilities . . . . . . . . . . . 6-7

6.2 .1 .3 Landfills ................. 6-7

Class I Landfill . . . . . . . . . . . . 6-7

Class IV Landfill . . . . . . . . . . . 6-7

Special Wastes ............... 6-8

6.3 Overview of Occupational Health and Safety .

Regulations ................... 6-8

6.3 .1 Federal Regulations . . . . . . . . . . . . . . . 6-8

6.3.2 State and Local Safety Requirements . . . . . . . . . 6-8

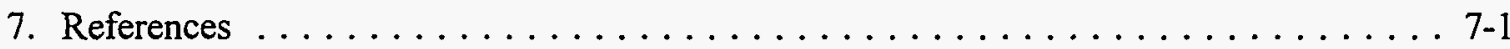

Appendix A: Glossary of Terms

Appendix B: Allocation of Costs and Result Tables

Appendix C: Methodology, Assumptions, and Data Used to Calculate Costs

Appendix D: Capital Cost Calculation 


\section{List of Figures}

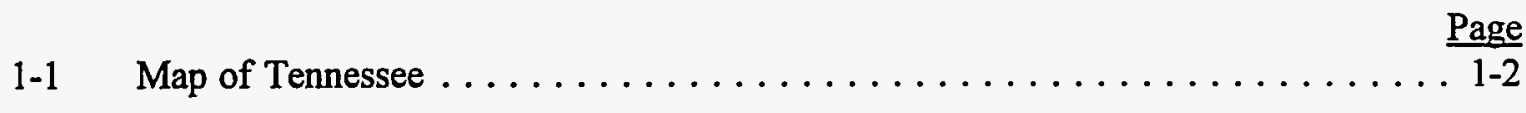

1-2 Map of Sevier County $\ldots \ldots \ldots \ldots \ldots \ldots \ldots \ldots \ldots \ldots \ldots \ldots \ldots$

2-1 Location of Solid Waste Management Facilities $\ldots \ldots \ldots \ldots \ldots \ldots \ldots$

2-2 Sevier Solid Waste New Class I Landfill Site Plan $\ldots \ldots \ldots \ldots \ldots \ldots \ldots$

2-3 Sevier Solid Waste Composting Facility Material Flow Diagram . . . . . . . 2-8

2-4 Sevier Solid Waste Composting Facility Floor Plan . . . . . . . . . . . 2-9

3-1 Sevier County Waste Flow and Resource Recovery Diagram $\ldots \ldots \ldots \ldots \ldots$ 3-3

3-2 City of Sevierville Waste Flow and Resource Recovery Diagram . . . . . . 3-4

\section{List of Tables}

$1-1 \quad 1990$ Population in Sevier County $\ldots \ldots \ldots \ldots \ldots \ldots \ldots \ldots \ldots \ldots \ldots$

3-1 Comparison of Total County and City Waste Quantities (FY 1993/94) . . . . . . 3-2

3-2 Sevier County Waste Quantities (FY 1993/94 Tons) $\ldots \ldots \ldots \ldots \ldots \ldots$. . . . .

3-3 City of Sevierville Waste Quantities (FY $1993 / 94$ tons) . . . . . . . . . . 3-7

3-4 Markets for Recovered Materials and Compost in FY 1993/94 . . . . . . . . . 3-14

4-1 City of Sevierville FY 1993/94 Total Waste and Analyzed MSW Tonnages

by Component $\ldots \ldots \ldots \ldots \ldots \ldots \ldots \ldots \ldots \ldots \ldots \ldots \ldots \ldots \ldots \ldots \ldots \ldots \ldots .2$

4-2 SSWI Revenues and Expenses Year Ending June 30, $1994 \ldots \ldots \ldots \ldots \ldots$. . . . 4-4

4-3 Total City Cost of Collection (FY $1993 / 94 \$) \ldots \ldots \ldots \ldots \ldots \ldots$

4-4 Total Gross and Net Costs of IMSWMS (FY 1993/94\$) . . . . . . . . . 4-7

4-5 Total Gross Costs of City IMSWMS Allocated by Functional Area

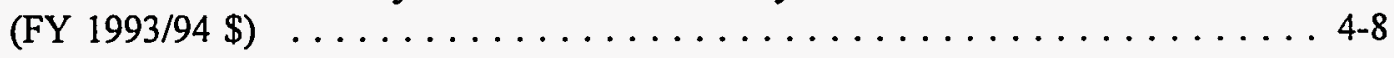

4-6 Total Revenues of City IMSWMS Allocated by Functional Area

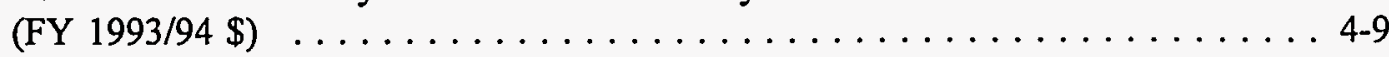




\section{List of Tables (Continued)}

4-7 Gross Costs of Managing Analyzed MSW by Functional Area

(FY 1993/94 \$)

4-8 Net Costs of Managing Analyzed MSW by Functional Area

(FY 1993/94\$)

4-9 Total Gross Costs of City IMSWMS Allocated by Type of Waste (FY 1993/94 \$)

4-10 Total Net Costs of City IMSWMS Allocated by Type of Waste (FY 1993/94 \$)

4-11 Incremental Cost of OCC Recovery Program (FY 1993/94) . . . . . . . . 4-13

4-12 Incremental Cost of the Composting Facility (FY 1993/94) . . . . . . . . 4-13

5-1 City of Sevierville Garbage Collection Vehicles $\ldots \ldots \ldots \ldots \ldots \ldots \ldots \ldots$ 5-2

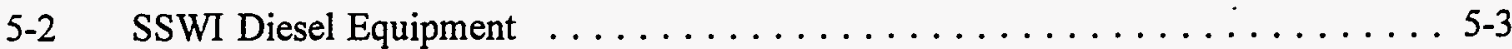

5-3 Energy Consumed to Collect Analyzed MSW in City of Sevierville (FY 1993/94) . . . . . . . . . . . . . . . . . . . . . . . . . 5-3

5-4 Mobile Equipment Used at Composting Facility $\ldots \ldots \ldots \ldots \ldots \ldots \ldots$

5-5 Total Energy Consumption for Managing Analyzed MSW (FY 1993/94) . . . . . 5-7

5-6 Equivalent Per Gallon Energy Consumption for Managing Analyzed MSW (FY 1993/94 Equivalent Diesel Gallons per Ton) . . . . . . . . . . . . . . . 5-9

6-1 Pollutants Regulated by the NPDES Permit Program $\ldots \ldots \ldots \ldots \ldots \ldots \ldots$. . $\ldots \ldots$

6-2 Maximum Contaminant Levels (MCL) Promulgated Under the Safe Drinking Water Act . . . . . . . . . . . . . . . . . . . . . 6-4

6-3 OSHA General Industry Standards -29 CFR $1910 \ldots \ldots \ldots \ldots \ldots \ldots$ 


\section{Introduction}

\subsection{Sevier County}

Sevierville is located in Sevier County, Tennessee (the County) and is the County seat. As shown in Figure 1-1, the County is located in the southeast portion of the state approximately 25 miles from Knoxville, Tennessee. Other municipalities in the County include Gatlinburg, Pigeon Forge, and Pittman Center, as shown in Figure 1-2. The 1990 populations of the municipalities and unincorporated areas are shown in Table 1-1.

Table 1. 1990 Population in Sevier County

\begin{tabular}{lrr}
\hline & 1990 Population & Percent of Population \\
\hline Sevierville & 7,178 & $14 \%$ \\
Gatlinburg & 3,417 & $7 \%$ \\
Pigeon Forge & 3,027 & $6 \%$ \\
Pittman Center & 478 & $1 \%$ \\
Unincorporated & 36,943 & $\mathbf{7 2 \%}$ \\
\hline TOTAL & $\mathbf{5 1 , 0 4 3}$ & $\mathbf{1 0 0 \%}$ \\
\hline
\end{tabular}

Source: U.S. Bureau of the Census.

Total population of the County in 1990 was approximately 51,043, the majority of which resided in unincorporated areas. The current estimated population for the County is approximately 54,600 . The County's population has approximately doubled since 1950 , with an average increase of about 2 percent per year. The University of Tennessee Department of Sociology has projected the County's population to increase to 63,057 by the year 2000 , approximately a 24 percent increase between 1990 and 2000. The estimated number of housing units in 1990 was 24,166.

Sevierville is the largest city in the County with a 1990 population of 7,178 . Sevierville was established in 1795 and was named, as was the County, after John Sevier, who served as the State's first governor. Tourism is an important part of Sevierville's economy, but Sevierville also boasts an industrial park with close to 20 industries and another industrial park scheduled to open soon.

Gatlinburg, with a 1990 population of approximately 3,417 , was so named in 1855 , although the town was settled in the late 1700 s. Being located very near the boundary of the Great Smoky Mountains National Park, Gatlinburg has grown at a rapid rate in the last 30 years due to tourism and provides a large number of restaurant and lodging facilities.

Pigeon Forge is located a few miles north of Gatlinburg and was primarily a farming community until the growth of tourism in the area. Although the tourism boom came later for Pigeon Forge than for Gatlinburg, tourism has grown significantly for Pigeon Forge since 1982. The 1990 population of Pigeon Forge was 3,027, approximately the same size as Gatlinburg. 


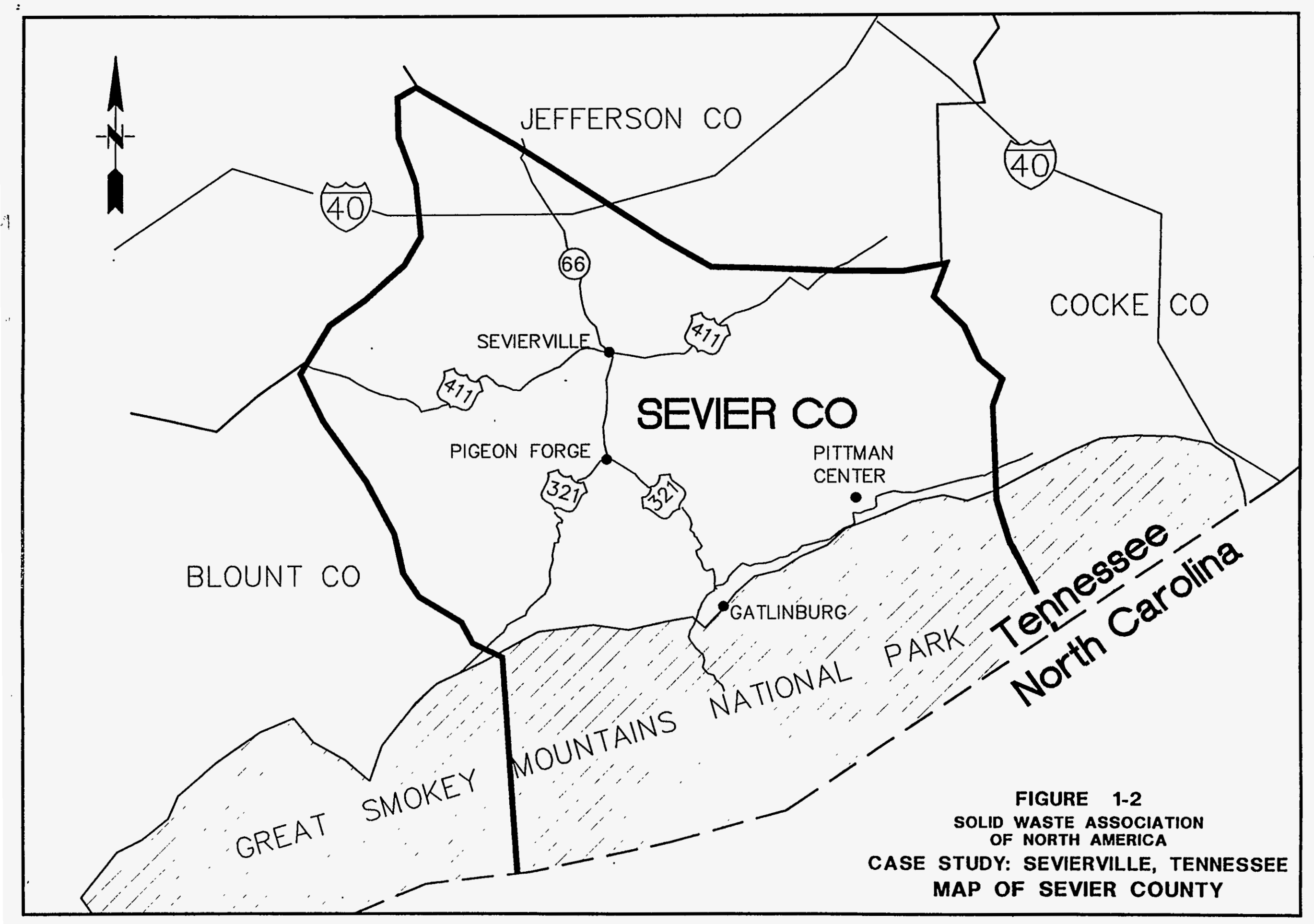


Pittman Center is the smallest community in the County with a 1990 population of 478 and the youngest community with an incorporation date of 1974. Pittman Center is primarily a farming and residential community.

The County encompasses approximately 600 square miles. One of the most important physiographic features in the area is the Great Smoky Mountains National Park, a portion of which is included in the eastern part of the County. Outside the National Park, the elevation in the County ranges from 942 feet to over 2,300 feet.

As a result of tourism, growth in the local economy in the County has increased dramatically since 1980. According to the U.S. Census of County Business Patterns, between 1980 and 1988, the number of service sector businesses and retail establishments increased by 50 percent. According to the State's Bureau of Economic Analysis, Local Planning Assistance, Department of Economic and Community Development (the Department), there may be as many as 150,000 people in the County during the peak tourist season, or three times the County 1990 Census.

\subsection{City of Sevierville}

Sevierville's current estimated population is 7,500. Since 1950, Sevierville's population has increased four-fold, with an annual growth rate of approximately 3.8 percent. The estimated number of housing units in 1990 was approximately 3,321 .

According to population projections prepared by the Department, the population in the year 2000 for Sevierville is projected to be between 6,898 and 10,601. The Sevierville Chamber of Commerce anticipates population to be at the upper end of this range which equates to a 48 percent increase between 1990 and 2000.

The average annual temperature in Sevierville is 55.2 degrees fahrenheit. Annual precipitation averages 51 inches, and annual average snowfall averages 20 inches. Prevailing winds are from the southwest. Sevierville is located 942 feet above sea level.

Sevierville is governed by a six-person board consisting of a mayor and aldermen. It also has a planning commission, board of public utilities, waterworks, and sewerage board of commissions, recreation commissioners, and housing authority.

\subsection{Waste Management}

During the 1980s, the City of Gatlinburg owned and operated a landfill that serviced the entire County. In 1988, it became apparent that the Gatlinburg landfill would soon reach its capacity and options other than the existing landfill required investigation.

In December 1988, Sevier Solid Waste, Inc. (SSWI) was formed as an intergovernmental venture between the County and the Cities of Sevierville, Gatlinburg, and Pigeon Forge to address waste management in the County. During 1990, the corporation took over operation of the landfill from Gatlinburg and began working with the Tennessee Local Planning Assistance Office (Planning Office) to develop and implement a comprehensive solid waste plan for the County. The Board of Directors of SSWI worked with the Planning Office to develop goals and objectives for the 
plan that were consistent with community ideals.

After several public hearings and unanimous approval by the governmental entities and the planning commissions in the County, the County Solid Waste Plan was officially adopted in October 1990. The recommendations in the plan provided the foundation for developing the integrated solid waste management facilities currently serving the entire County which are owned by SSWI.

The quantity of solid waste generated in the County during FY 1993/94 and managed in SSWI programs is estimated to be 66,710 tons. Approximately 13,750 tons or 21 percent by weight of the County's solid waste is estimated to have been generated in Sevierville. These quantities include municipal solid waste (MSW), as well as demolition waste, sewage sludge, and grease. The relatively high generation rate in Sevierville is probably due to the large amount of commercial waste generated by tourism. 


\subsection{Municipal Solid Waste Management System}

\subsection{Sevier Solid Waste, Inc.}

The Charter of Incorporation for SSWI was signed on December 7, 1988. The existence of SSWI was authorized under an Interlocal Cooperation Agreement dated November 30, 1988 (Interlocal Agreement) between the County and the Cities of Gatlinburg, Pigeon Forge, and Sevierville. The charter specifies that the corporation is a not-for-profit corporation.

The primary purposes of SSWI set forth in the Charter are to:

- $\quad$ Receive and administer funds to acquire, construct, equip, and maintain a solid waste landfill and related facilities for the County;

- $\quad$ Arrange for the disposal of solid waste through appropriate disposal methods or to contract with others for the hauling or disposal of such solid waste.

The Charter provides SSWI with powers, privileges, rights, and immunities necessary or convenient for carrying out the purposes for which it was formed. These include the power to contract indebtedness including bonds and enter into contracts and leases with other entities.

SSWI is managed by a board of directors made up of one member from each of the three municipalities listed above and the County. Each director's vote carries the weight of the director's proportionate interest determined by their municipality's respective landfill tonnages at the time the Interlocal Agreement was signed. Respective quantities of waste managed in the SSWI facilities is also used to determine the relative amount paid by each local government for use of the SSWI facilities. Pittman Center is not a member of the Interlocal Agreement but uses the SSWI facilities.

In the administration of SSWI, each of the board members reports to its respective council or commission. A Solid Waste Advisory Committee was also established in 1988 to further link SSWI with the public.

\subsection{System Overview}

The County's FY 1993/94 IMSWMS consisted of the following integrated System components:

- Collection of residential and commercial garbage and demolition wastes by the cities and the County;

- Collection of old corrugated containers (OCC) from businesses by SSWI and processing in a recycling warehouse owned and operated by SSWI;

- Drop-off collection and recycling of aluminum, plastic, and newspapers by a private hauler under contract with SSWI;

- Drop-off collection and recycling of used motor oil by a private hauler;

- A mixed waste composting facility with ferrous recovery capabilities owned by SSWI and 
operated for SSWI by a private contractor, Bedminster Bioconversion Corporation (Bedminster);

- A new Class I landfill and extension to an old landfill owned and operated by SSWI for the disposal of residue from the compost facility and bypass garbage;

- A Class IV landfill with ferrous, wood, and tire recovery capabilities owned and operated by SSWI for the recycling and disposal of construction and demolition debris, tires, and other bulky wastes; and

- Public information and education programs.

Solid waste is defined in this report as including MSW, as well as demolition waste, sewage sludge, and grease, all of which are managed by SSWI. MSW includes garbage from residential and commercial sources, recyclables, bulky wastes, and household hazardous waste (HHW). A Glossary of Terms is provided in Appendix A for a more detailed definition of these and other terms used in the document.

A description of each of the individual components of the County's IMSWMS follows. Locations of the various facilities in the County are shown in Figure 2-1.

SSWI's compost facility, recycling warehouse, and Class I landfill are located on the same site. A site layout is shown in Figure 2-2. This site is approximately 5 miles from Sevierville. The Class IV landfill and old landfill extension are within close proximity to the compost facility site.

The size of the site on which the SSWI facilities are located is approximately 155 acres in size which is utilized as follows:

$\begin{array}{llr}\text { - } & \text { Class I landfill } & 35 \text { acres } \\ \text { - } & \text { Compost facility } & 10 \text { acres } \\ \text { - } & \text { Recycling warehouse } & 5 \text { acres } \\ & \text { Buffer } & 105 \text { acres }\end{array}$

A scale house is located on the SSWI site and is operated primarily by an employee of the County with some assistance from SSWI employees. All waste and materials going to SSWI facilities (Class I and IV landfills, compost facility, or recycling warehouse) and materials leaving SSWI facilities are weighed at the scale house. It is open Monday through Friday from 7:00 a.m. to 2:00 p.m. and Saturday from 7:00 a.m. to 11:00 p.m.

\subsection{System Component Descriptions}

\subsubsection{Garbage and Demolition Waste Collection}

Each of the municipalities in the County operate their own garbage collection systems. Door-todoor service is provided in the incorporated areas. In addition, eleven "convenience centers" are provided by the County in unincorporated areas. Convenience centers are drop-off sites for garbage and recyclables. Garbage collected by the cities and the County is taken to the SSWI 


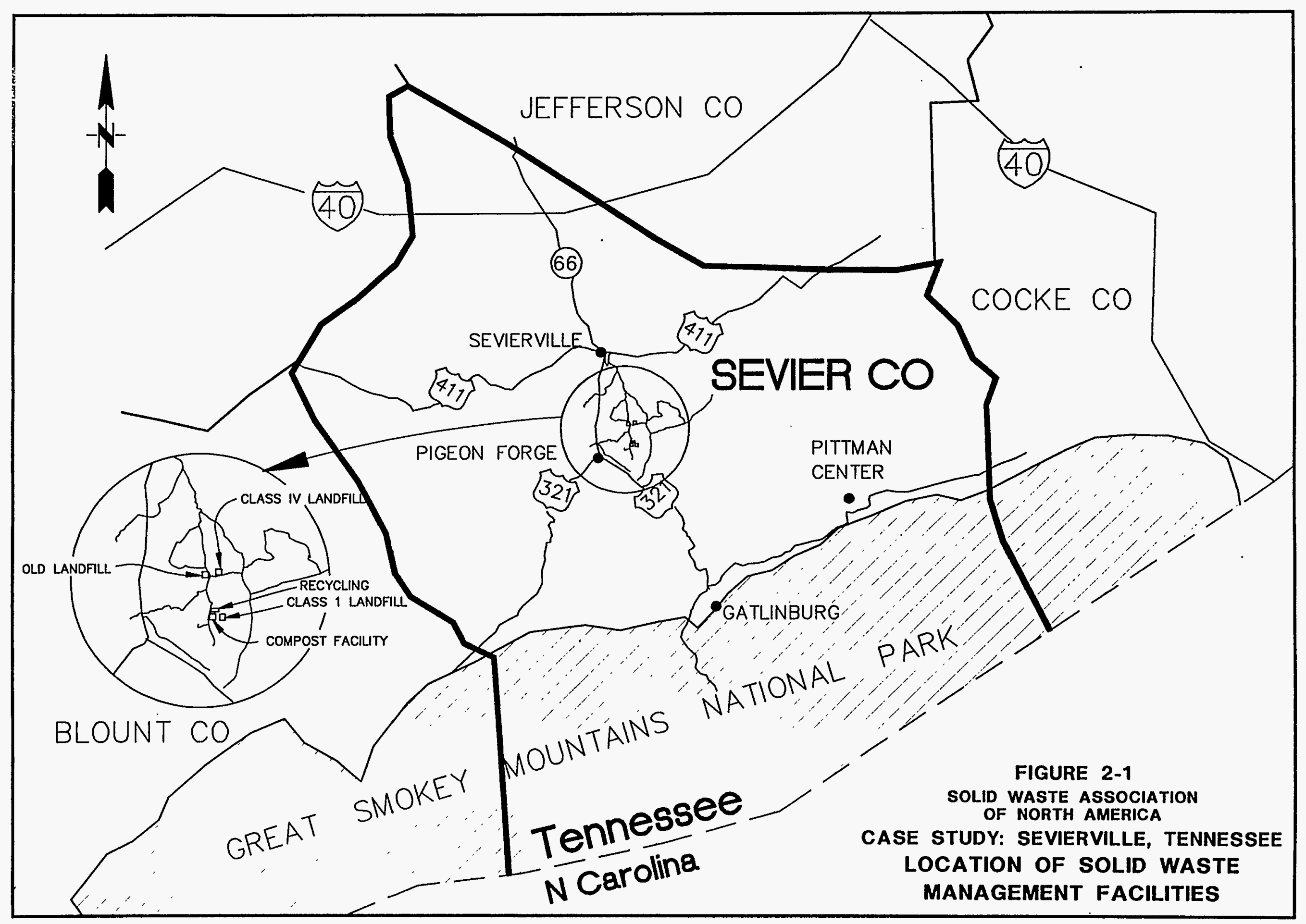


facilities.

Sevierville's Sanitation Department collects garbage Monday through Friday from all residential dwellings on a once per week basis. The approximate number of dwelling units served in FY $1993 / 94$ was 1,950 .

Sevierville's Sanitation Department also collects garbage from all commercial businesses and institutions. Collection schedules vary between businesses. Approximately 663 businesses were provided with service in FY 1993/94.

Sevierville's Sanitation Department collection fleet consists of six vehicles crewed by a total of eight persons:

- Three rear-end loaders for collection of residential garbage and garbage from small commercial accounts (mainly in-home businesses), and

- Three front-end loaders for collection of garbage from larger commercial accounts.

Managers of multi-family dwellings may choose whether they want commercial dumpster service or residential type service.

Sevierville's Streets Department also provides collection of demolition (including bulky) wastes to residents and businesses. Two dump trucks with clamshells run on regular routes throughout Sevierville for this purpose.

\subsubsection{Commercial Corrugated Collection and Processing}

SSWI has placed dumpsters behind over forty businesses in the County for separate collection of OCC. Approximately 75 percent of the dumpsters are located in Pigeon Forge, with the balance in Gatlinburg and Sevierville. A 25 cubic yard side-loader operated by an SSWI employee collects the OCC on a twice per week basis and brings it to the recycling warehouse for baling.

The recycling warehouse is a 12,000 square foot building that was completed in 1993 . At the warehouse, the $\mathrm{OCC}$ is baled in 1,500 pound bales and truckload quantities ( 20 tons) are hauled by Knoxville Recycled Fiber Company to Rock Tenn Paper Company in Chattanooga for recycling. The OCC is sold to Rock Tenn under a long-term contract.

Two SSWI employees operate the collection vehicle and recycling warehouse.

\subsubsection{Drop-Off Recyclables Collection}

SSWI provides drop-off collection of newspaper, aluminum, and HDPE and PET plastics for recycling at six locations throughout the County through a contract with Waste Management. One of six drop-off locations is in Sevierville. The compartmentalized roll-off containers used at the sites are owned by Waste Management.

Waste Management collects the recyclables from the drop-off sites and delivers them to Lakeway 
Recycling in Morristown, approximately 40 miles from Sevierville. Lakeway processes the materials and sells them to multiple remanufacturers.

\subsubsection{Drop-Off Used Motor Oil Collection}

Eleven drop-off sites for used motor oil are located throughout the County. Four of these drop-off sites are the same as recyclables drop-off locations. Only one drop-off site for used oil is located in Sevierville, and it is not at the same location as the recyclables drop-off. Industrial Oil Service of Knoxville supplies the waste motor oil containers and provides the collection services. No cost is incurred by SSWI or the local governments for this program.

\subsubsection{Sevier Solid Waste Composting Facility}

The composting facility receives garbage and sewage sludge from all of the County's residents and 8 million yearly visitors. The design capacity for the facility is 225 tons per day total: 150 tons of MSW and 75 tons of sewage sludge. In addition to garbage and sewage sludge, the facility also receives some wastewater treatment grease trap waste and restaurant grease, as well as sludge imported from outside the County. A materials flow diagram and floor plan for the composting facility are shown in Figures 2-3 and 2-4.

SSWI contracted with Bedminster of New Jersey in September 1991 to build the facility. Bedminster was also contracted to operate the facility for five years. Bedminster developed the proprietary technology which it employs for co-composting MSW and sewage sludge. The County facility is the third composting facility in the United States employing the Bedminster technology.

The facility began operations in October 1992. The quantities of MSW received at the facility vary with the influx of tourists. In July 1993, 5,090 tons of MSW were received at the composting facility. This was 1,340 tons per month over the design capacity of the facility. The operators are able to accommodate the excess tonnage by maximizing the capacity at each stage of the composting process. Thus, the facility is capable of processing waste quantities beyond its designed capacity.

Material received at the facility is weighed in at the County-operated scale house located approximately 400 feet from the facility's tipping floor. Loads containing construction and demolition wastes are directed to the Class IV Landfill. Sludge cake (15 to 20 percent solids) is normally received on the tip floor. A sludge storage building is available for additional storage of sludge cake. Loads of liquid sludge, grease trap waste, and restaurant grease are deposited in an underground holding tank. The holding tank also receives wastewater from the facility's office, tipping floor, and curing building.

Tip floor workers remove bulky items such as furniture and bicycles and hazardous items from the garbage. The remaining material is fed via front-end loaders into hydraulic ram pits. The exact ratio of sludge to garbage in the feedstock mixture varies by season. However, a typical feedstock blend is one bucket of sludge with two buckets of garbage.

The ram pits feed material into one of three rotating drum digesters. Each steel digester is 184 
feet long and has a 12 foot diameter. Liquid from an underground water holding tank can be pumped into the first compartment of the digester to achieve the targeted operating moisture content of 55 percent. The digester rotating speeds and retention times are variable. However, they typically turn at one rotation per minute and hold material for three days. The drums are separated into three chambers, corresponding to three distinct phases of microbial activity.

Microbial activity is a function of temperature, moisture, substrate availability, and oxygen availability. The conditions achieved in the digester are intended to produce an optimal rate of microbial digestion. Ambient building air from the aeration building is used to provide oxygen to the microbes in the digester. This air is introduced into the third chamber and is collected as it leaves the first chamber. The continuous tumbling of material inside the drums serves two purposes. The average particle size is drastically reduced due to the constant battering and maceration it receives in the drums. As the particle size is reduced surface area is made available for microbial attack. The continuous turning also helps provide mixing and redistribution of oxygen and nutrients required for microbial growth.

Material exiting the drums is dropped onto a conveyor which feeds the material into the primary trommel screen. The 1.25 inch screen separates the non-organics (plastic containers, film plastics, tin cans, etc.) from the organic fraction. Approximately 30 percent of the material is rejected as non-organic material at the primary trommel. The non-organic fraction is passed under a magnetic belt separator which pulls out the ferrous metals. The recovered ferrous metals are currently being sold to a scrap metals company in Rockwood, Tennessee. After processing, they are sold to steel mills throughout the South. The remaining residue is loaded into a trailer located in a truck bay under the tipping floor. The residue is disposed of at the adjacent Class I landfill.

The remaining organics are formed into bays in the aeration building. Microbial activity is reactivated in this stage to further decompose the organics. The retention time of material on the aeration floor is 4 to 6 weeks. During the heavy tourist season, the operators stack material up to 10 feet tall. However, control of the process is more effective at smaller pile dimensions. Half of the bays are laid out on the east side of the building and the other half are laid out on the west side. The material is laid out over aeration pipes which are recessed in the concrete floor of the building. Air is forced, under positive pressure, through the piles. This is done to provide oxygen to the microbes and to regulate temperatures within the piles. Large, plastic hoods collect air over each bay. The hoods collect air at a greater rate than is blown through the aeration pipes. This helps ensure that all of the process air from the building is captured. The bays are agitated by bucket loaders down the length of the building perpendicular to the pile length.

Material that has reached the north end of the curing building is conveyed to the final screening area. After screening, material that is less than $3 / 16$ inch size is placed in finished compost piles in the storage building. The material greater than $3 / 16$ inch, but less than $3 / 8$ inch, is sent to one of two destoners. The destoners are fluidized bed separators which remove small pieces of glass, rocks, stones, film, plastic, and sharps from the compost. The material greater than $3 / 8 \mathrm{inch}$, and less than $3 / 4$ inch, is brought back to the tipping floor to be mixed with the dewatered sludge. This mixture serves as an inoculant for the feedstock at the beginning of the cycle. Material greater than $3 / 4$ inch is landfilled. 


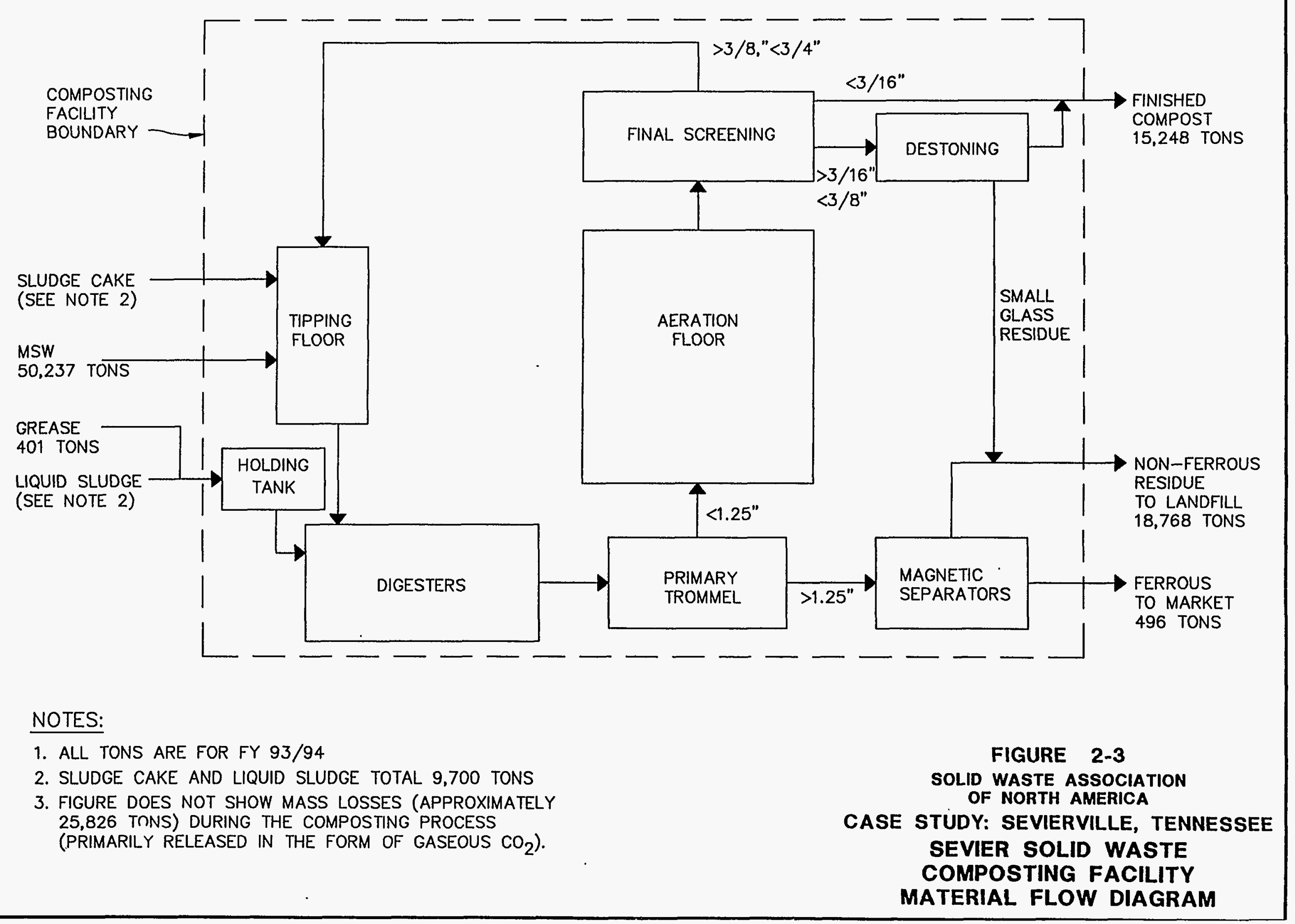




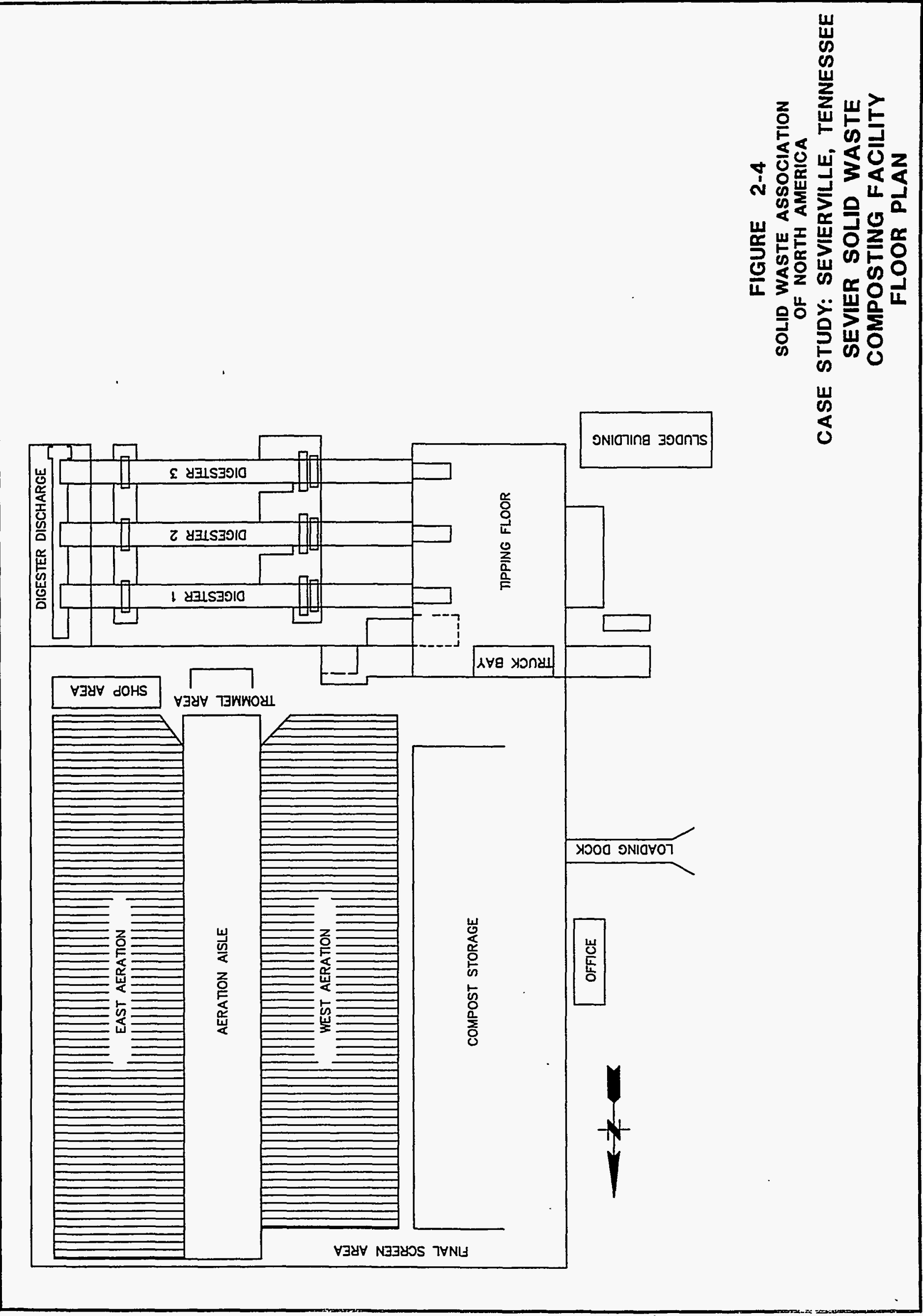


Process air from the curing building and digesters passes through biofilters prior to being dispersed. Three biofilter areas service process air from the digester, holding tank, and the tipping and curing buildings. The biofilters on the east and north side of the facility handle process air from the aeration building. The process air from the digesters, tipping building, and the holding tank are sent through the biofilters on the south side of the building. The biofilter media is three feet in depth and rests on top of perforated pipes on a gravel base. The biofilter is comprised of a mixture of wood chips, mulch (ground bark), finished compost, and sand. Odorous compounds are scrubbed from the process air by the filter media. The facility contains approximately 35,000 square feet of biofilter area.

Finished compost goes to some form of beneficial use. Much of the material is given away in an effort to develop markets for the material. Uses include agricultural research, landscaping, athletic fields, and parks. The price for the material that is sold is approximately $\$ 10.00$ per ton. However, as markets are currently being established, the majority of the material is being given away.

Fourteen employees are on the Bedminster facility's payroll. This includes ten laborers over two shifts, two maintenance workers, one plant manager, and one receptionist/secretary. The facility is currently operating seven days a week. The first shift begins at 4:00 a.m. and the last shift ends at 8:00 pm. Two other Bedminster employees are present at the facility but are not on the facility's payroll. These two employees are in charge of conducting facility tours and marketing the end product.

\subsubsection{Class I Landfills}

SSWI operated two landfills for the disposal of bypass garbage and residue from the composting facility during FY 1993/94. Bypass garbage is garbage that is not processed through the composting facility on occasion due to a lack of capacity. Residue from the compost facility is screened out of the process, and consists primarily of plastics. Between June and October 1993, residue and bypass waste were disposed of at an extension to the old the County Landfill (Old Landfill Extension) on the west side of Ridge Road. Upon closure of the Old Landfill Extension, bypass garbage and residue were disposed of in a new Class I landfill located on the same site as the composting facility and recycling warehouse.

The old County Landfill consisted of four phases. Phases I and II received waste between the mid-1970s through the late 1980s. Phase III was operated from the late 1980s until October 1991, and closure of Phase III was completed under an approved closure plan in the summer of 1992.

The Old Landfill Extension was a 3.5-acre area between Phases I and II, which had not been used previously. It began operation in October 1991 and was closed in October 1993.

The Old Landfill Extension has a three-foot clay liner with a permeability of $1 \times 10^{-7} \mathrm{~cm} / \mathrm{sec}$ and a leachate collection system. Leachate was collected in a tank and then pumped to a truck and taken to one of the wastewater treatment plants in the County. The Old Landfill Extension closure consisted of a two-foot clay liner with a permeability of $1 \times 10^{-7} \mathrm{~cm} / \mathrm{sec}$ and one foot of topsoil. 
The new Class I landfill is located on the same site as the composting facility and recycling warehouse. This landfill's design meets the requirements of RCRA Subtitle D and consists of three permitted phases: Phases IV A, B, and C. These phases were shown in Figure 2-2. Phase IV A has been subdivided into Parts 1 and 2. Phase IV A - Part 1 is approximately 2 acres in size. Landfilling of bypass garbage and residue from the compost facility in Part 1 began in October 1993 and was suspended in October 1994. However, additional lifts will be placed on Part 1 as filling of Part 2 progresses. Operation of Phase IV A - Part 2 began in October 1994 and this phase is currently being utilized. Phase IV A, Part 2 is approximately 4 acres in size. To date, Phases IV B and C have not been developed. The combined size of Phase IV A, B, and $\mathrm{C}$ is approximately 25 acres.

Phase IV A reportedly has three liners: a five-foot clay liner with a permeability of $1 \times 10^{-6}$ $\mathrm{cm} / \mathrm{sec}$, a three-foot clay liner with a permeability of $1 \times 10^{-7} \mathrm{~cm} / \mathrm{sec}$, and a $60 \mathrm{mil}$ high density polyethylene (HDPE) liner. SSWI was granted a variance to allow a total liner/geologic buffer thickness of six feet as compared to the eight feet reportedly utilized. The Phase IV A leachate collection system consists of approximately 850 linear feet of 6-inch diameter pipe and a leachate collection tank which is an epoxy-coated manhole. Each of the three phases of Phase IV will have independent leachate collection tanks. A vacuum truck is used to remove leachate from the leachate collection system. The leachate is taken to wastewater treatment plants in Gatlinburg, Sevierville, and Pigeon Forge for treatment and disposal.

The clay used to construct the landfill liner and the daily cover material is located on site. In FY 94/95, in an effort to conserve landfill space, SSWI began using a geomembrane for daily cover.

During construction of Phase IV A, Part 1, an access road was constructed for the entire Phase IV landfill development and a sedimentation pond was constructed which will serve Phase IV A and a portion of Phase IV B. The sedimentation pond is part of the surface water control system for the Phase IV landfill. Groundwater monitoring wells were also installed and groundwater from the wells is sampled and analyzed to determine groundwater characteristics.

The Class I landfill has two full time operators. The operators spread and compact the waste received and place daily cover.

\subsubsection{Class IV Landfill}

In April 1993, SSWI began operating a Class IV demolition landfill. The only types of wastes accepted at this site include construction and demolition waste and bulky wastes including tires. The size of the site is approximately 14 acres of which 3 acres is used for landfilling. This landfill is not lined and cover is applied once per month.

Metal items including white goods are placed in a roll-off container provided by Tidi Waste. Tidi Waste hauls the metals to Morristown Shredders in Morristown, Tennessee for intermediate processing. Wood pallets are stockpiled and given to a local business to be reused. Other wood waste, such as brush, is mulched by utilizing a tub grinder and given away to local residents free of charge.

The Class IV landfill site also contains a state-permitted tire storage area. Tires are shredded 
periodically by a contractor hired by the State and stockpiled for future market development. The storage site has a maximum capacity of approximately 30,000 tires.

This landfill has two operators, one of which works part-time at the SSWI scale house.

\subsubsection{Public Information and Education Programs}

SSWI developed an educational program in conjunction with the 4-H clubs in the County to teach children in the schools about the County's solid waste system. Fourth through sixth graders throughout the County participate in this educational program which includes viewing a video of the composting plant, essay and public speaking contests about composting, educational programs on reduction of solid waste, a poster contest concerning the proper disposal of used motor oil, and a tour of the composting and recycling facilities. Several thousand visitors from all over the country visit the compost facility each year.

In addition, SSWI has developed a scale model of the composting facility. This model is rotated throughout the County in different locations (schools, libraries, welcome centers, etc.). A local library in Gatlinburg developed a brochure to answer questions regarding the plant and the County's overall MSW management program, and developed a speaker's bureau to assist local organizations in obtaining speakers such as the general manager and board members of the SSWI for their meetings. Every local civic organization has seen an SSWI slide show presentation on the County's solid waste program. Numerous articles have been written and published on a local and national basis regarding the solid waste management system in the County, particularly the mixed waste composting facility. 


\section{Municipal Solid Waste Quantities}

A total of approximately 72,300 tons of waste, 66,700 tons of waste from the County and 5,600 tons of imported sludge, were managed in SSWI programs in FY 1993/94. Of this amount, approximately 13,800 tons (19 percent by weight) were from Sevierville. No solid waste is reportedly exported out of the County and sludge was the only type of imported waste.

A comparison of Sevierville and total County waste quantities including imported sludge is shown in Table 3-1 by waste category.

The approximate percent by weight of each category in Sevierville's waste stream is as follows:

- Garbage (residential, commercial, and self-haul): $\quad 75 \%$

- Recyclables (drop-off and commercial corrugated): $\quad<1 \%$

- $\quad$ HHW (used motor oil): $\quad<1 \%$

- Demolition waste (including tires and bulky wastes): $14 \%$

- $\quad$ Sludge/grease: $\quad 11 \%$

Figure 3-1 is a waste flow diagram for the County which includes FY 1993/94 tonnages. Table 3-2 shows the sources of data and methodology used to estimate the waste quantities shown in Figure 3-1.

Figure 3-2 is a waste flow diagram for waste generated in Sevierville and includes FY 1993/94 tonnages. Table 3-3 shows the sources of data and methodology used to estimate the waste quantities shown in Figure 3-2. 
Table 3-1. Comparison of Total County and Sevierville Waste Quantities (FY 1993/94)

\begin{tabular}{|c|c|c|}
\hline \multirow[b]{2}{*}{ Type } & \multicolumn{2}{|c|}{$\begin{array}{l}\text { Waste Quantities Handled by SSWI } \\
\text { Programs }\end{array}$} \\
\hline & Total System & City of Sevierville \\
\hline Garbage & $51,043^{\text {[a] }}$ & $10,280^{[b]}$ \\
\hline Recyclables: & 464 & 62 \\
\hline Drop-Off & $220^{[c]}$ & $31^{[d]}$ \\
\hline Commercial Corrugated & $244^{[\mathrm{e}]}$ & $31^{[\text {[e] }}$ \\
\hline HHW (Used Motor Oil) & $10^{[?]}$ & $1^{[d]}$ \\
\hline Demolition Waste (including tires) & $10,708^{\text {[a] }}$ & $1,905^{[b]}$ \\
\hline Sludge/Grease & $10,101^{\text {[a] }}$ & $1,503^{[b]}$ \\
\hline $\begin{array}{l}\text { Sludge/Grease from Local } \\
\text { Community(s) }\end{array}$ & $4,489^{\text {[a] }}$ & $1,503^{[b]}$ \\
\hline Imported Sludge & $5,612^{[a]}$ & N/A \\
\hline TOTAL & 72,326 & 13,751 \\
\hline
\end{tabular}

Notes:

Taken from scalehouse records compiled by SSWI.

Taken from scalehouse records compiled by Sevierville.

Estimated by SSWI.

Estimated based on total County tonnages by assuming quantities are proportional to population.

SSWI estimated that 75 percent of commercial corrugated was collected in Pigeon Forge. One-half of the remaining 25 percent was assumed to come from Sevierville.

SSWI estimated approximately 2,700 gallons were collected. This quantity was converted to tons assuming used motor oil has a density of 54.9 pounds per cubic foot. 
SEVIER COUNTY TENNESSEE (FY 83/94 TONS)

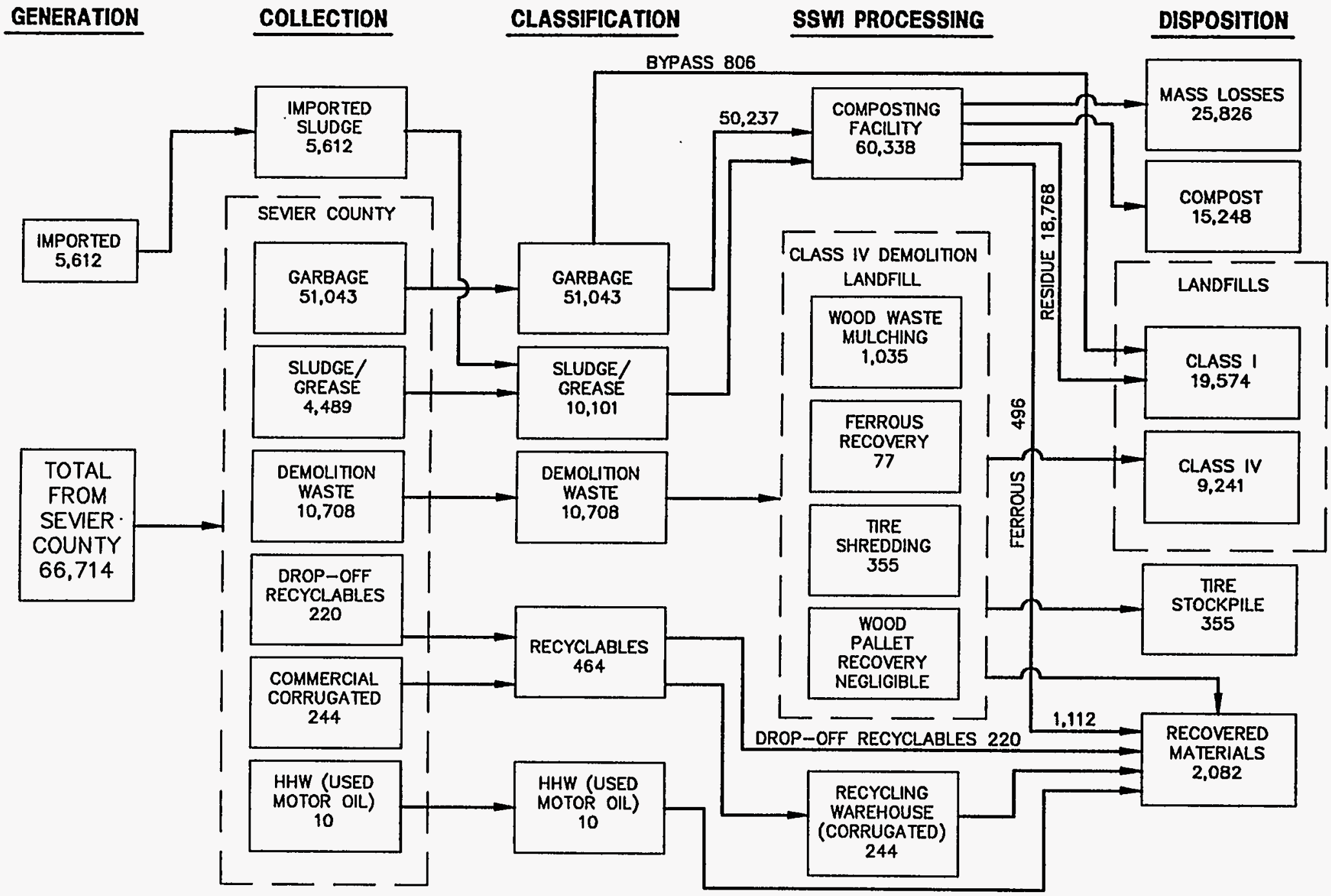

FIGURE $\quad 3-1$

SOLID WASTE ASSOCIATION

OF NORTH AMERICA

CASE STUDY: SEVIERVILLE, TENNESSEE

WASTE FLOW AND

RESOURCE RECOVERY DIAGRAM 
CITY OF SEVIERVILLE, TENNESSEE (FY 93/94 TONS)

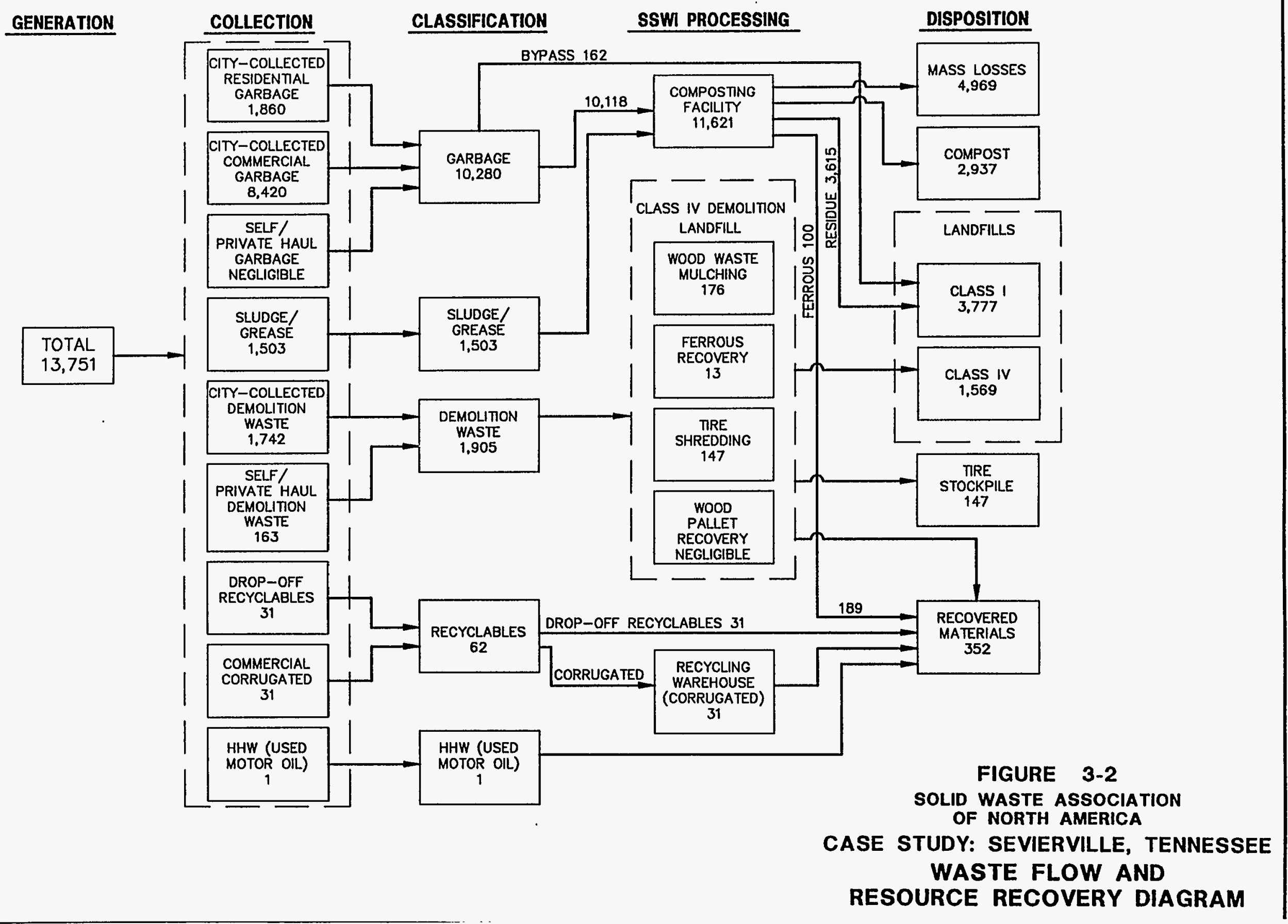


Table 3-2. Sevier County Waste Quantities (FY 1993/94 Tons)

\begin{tabular}{|c|c|c|}
\hline$\ldots \quad:$ & TPY (subtotal) & TPY \\
\hline \multicolumn{3}{|l|}{ Generation } \\
\hline Total from Sevier County & & $66,714^{[\mathrm{a}]}$ \\
\hline Imported Sludge & & $5,612^{[b]}$ \\
\hline Total Generation & & 72,326 \\
\hline \multicolumn{3}{|l|}{ Collection } \\
\hline Garbage & & $51,043^{[b]}$ \\
\hline Sludge/Grease from within County & & $4,489^{[b]}$ \\
\hline Imported Sludge & & $5,612^{[b]}$ \\
\hline Demolition Waste & & $10,708^{[c]}$ \\
\hline Drop-Off Recyclables & & $220^{[d]}$ \\
\hline Commercial Corrugated & & $244^{[b]}$ \\
\hline HHW (used motor oil) & & $10^{[e]}$ \\
\hline Total Collection & & 72,326 \\
\hline \multicolumn{3}{|l|}{ Classification } \\
\hline Garbage & & $51,043^{[b]}$ \\
\hline Sludge/Grease & & $10,101^{[\mathfrak{1}}$ \\
\hline Recyclables & & $464^{[s]}$ \\
\hline Demolition Waste (incl. tires) & & $10,708^{[c]}$ \\
\hline HHW & & $10^{[e]}$ \\
\hline Total Classification & & 72,326 \\
\hline \multicolumn{3}{|l|}{ Processing } \\
\hline Composting Facility & & $60,338^{[\mathrm{h}]}$ \\
\hline Wood Waste Mulching & & $1,035^{[\mathrm{i}]}$ \\
\hline Ferrous Recovery & & $77^{[\mathrm{j}]}$ \\
\hline Tire Shredding & & $355^{[b]}$ \\
\hline Pallet Exchange & & Neg. ${ }^{[k]}$ \\
\hline Recycling Warehouse & & $244^{(n)}$ \\
\hline Total Processing & & $62,049^{[m]}$ \\
\hline
\end{tabular}




\section{Disposition}

Compost

$15,248^{[n]}$

Class I Landfill

$19,574^{[b]}$

Bypass Garbage

$806^{[0]}$

Residue

$18,768^{[n]}$

Class IV Landfill

$9,241^{[p]}$

Tire Stockpile

Recovered Materials

Drop-Off Recyclables

$220^{[\mathrm{d}]}$

Commercial Corrugated

$244^{[\mathrm{b}]}$

HHW (used motor oil)

$10^{[\mathrm{e}]}$

Class IV Materials

$1,112^{[q]}$

Ferrous from Compost Facility

$496^{[\mathrm{b}]}$

Total Disposition

Notes:

(a) Includes garbage, sludge, grease, recyclables, demolition waste, and used motor oil.

[b] Taken from scalehouse records compiled by SSWI.

(c) Taken from scalehouse records compiled by SSWI. Includes construction and demolition debris, bulky waste other wood waste, and tires.

[d] Estimated by SSWI.

IcI SSWI estimated approximately 2,700 gallons were collected. This quantity was converted to tons assuming motor oil has a density of 54.9 pounds per cubic foot.

In Includes imported sludge and sewage sludge and grease from with the county.

[e] Includes drop-off recyclables and commercial corrugated.

ib] Includes garbage and sludge/grease less bypass waste.

i1) Based on information in Regional Plan assumed to be 10 percent by weight of demolition waste excluding tires.

bl Based on scale receipts from intermediate processor.

(1) Data not available to estimate but assumed to be negligible

III Commercial corrugated is baled in recycling warehouse.

[m] Total does not equal Generation Total due to materials bypassing processing programs.

[n] Based on Bedminster records.

|ol Equal to total tonnage to Class I landfill based on scalehouse records less compost residue quantities from Bedminster records.

[p] Equal to total demolition waste quantity less materials removed from demolition was at Class IV landfill including woodwaste, ferrous, and tires.

[q] Includes wood waste and ferrous recovered at Class IV landfill for recycling and reuse.

if) Total does not equal Generation Total due to processing loss (primarily moisture loss during composting). 
Table 3-3. City of Sevierville Waste Quantities (FY 1993/94 Tons)

\begin{tabular}{|c|c|c|}
\hline & TPY subtotal & TPY \\
\hline Generation & & $13,751^{[a]}$ \\
\hline \multicolumn{3}{|l|}{ Collection } \\
\hline Garbage & & 10,280 \\
\hline \multicolumn{3}{|l|}{ Collected by City } \\
\hline Residential & $1,860^{[b]}$ & \\
\hline Commercial & $8,420^{[\mathrm{b}]}$ & \\
\hline Self/Private Haul & Neg. ${ }^{[c]}$ & \\
\hline \multicolumn{3}{|l|}{ Sludge/Grease } \\
\hline Collected by City & & $1,503^{[b]}$ \\
\hline Demolition Waste (incl. tires) & & $1,905^{[e]}$ \\
\hline Collected by City & $1,742^{[b]}$ & \\
\hline Self/Private Haul Tires & $147^{[\mathrm{d}]}$ & \\
\hline Self/Private Haul Other & $16^{[\mathrm{cc}]}$ & \\
\hline Drop-Off Recyclables & & $31^{\text {[f] }}$ \\
\hline Commercial Corrugated & & $31^{[\mathrm{g}]}$ \\
\hline HHW & & $1^{\text {[?] }}$ \\
\hline Total Collection & & 13,751 \\
\hline \multicolumn{3}{|l|}{ Classification } \\
\hline Garbage & & $10,280^{[b]}$ \\
\hline Sludge/Grease & & $1,503^{[\mathrm{b}]}$ \\
\hline Recyclables & & $61^{[\mathrm{h}]}$ \\
\hline Demolition Waste (incl. tires) & & $1,905^{[\mathrm{e}]}$ \\
\hline HHW & & $1^{\text {[n }}$ \\
\hline Total Classification & & 13,751 \\
\hline \multicolumn{3}{|l|}{ Processing } \\
\hline Composting Facility & & $11,621^{[1]}$ \\
\hline Wood Waste Mulching & & $176^{[\mathrm{ij}]}$ \\
\hline Ferrous Recovery & & $13^{[k]}$ \\
\hline Tire Shredding & & $147^{[b]}$ \\
\hline Pallet Exchange & & Neg. [I] \\
\hline
\end{tabular}


Table 3-3. City of Sevierville Waste Quantities (FY 1993/94 Tons)

\begin{tabular}{|c|c|c|}
\hline & TPY subtotal & TPY \\
\hline Recycling Warehouse & & $31^{[\mathrm{m}]}$ \\
\hline Total Processing & & $11,988^{[n]}$ \\
\hline \multicolumn{3}{|l|}{ Disposition } \\
\hline Compost & & $2,937^{[0]}$ \\
\hline Class I Landfill & & 3,777 \\
\hline Bypass Garbage & $162^{[p]}$ & \\
\hline Residue & $3,615^{[q]}$ & \\
\hline Class IV Landfill & & $1,569^{[r]}$ \\
\hline Tire Stockpile & & $147^{[\mathrm{d}]}$ \\
\hline Recovered Materials & & 352 \\
\hline Drop-Off Recyclables & $31^{[\mathfrak{f}]}$ & \\
\hline Commercial Corrugated & $31^{[\mathrm{g}]}$ & \\
\hline Used oil & $1^{[\mathrm{f}]}$ & \\
\hline Class IV Materials & $189^{[s]}$ & \\
\hline Ferrous from Compost Facility & $100^{[t]}$ & \\
\hline Total Disposition & & $8,782^{|u|}$ \\
\hline
\end{tabular}


Table 3-3. City of Sevierville Waste Quantities (FY 1993/94 Tons)

\begin{tabular}{|c|c|}
\hline & TPY subtotal \\
\hline \multicolumn{2}{|c|}{ Notes: } \\
\hline [0] & Includes garbage, sludge, grease, recyclables, demolition waste, and used motor oil. \\
\hline [b] & Taken from scalehouse records compiled by Sevieville. \\
\hline [c] & $\begin{array}{l}\text { Scalehouse records compiled by Sevierville indicate total of } 16 \text { tons of garbage/demolition waste were } \\
\text { delivered by private haulers and citizens to SSWI facilities. Data were not available to break out garbage } \\
\text { quantities from demolition quantities, so it was all assumed to be demolition waste. }\end{array}$ \\
\hline [d] & Taken from scalehouse records compiled by Sevierville which shows all tires were privately/self hauled. \\
\hline [द] & $\begin{array}{l}\text { Taken from scale house records compiled by Sevierville. Includes construction and demolition debris, bulky } \\
\text { waste, other woodwaste, and tires. }\end{array}$ \\
\hline In & Estimated based on total County tonnages by assuming quantities are proportional to population. \\
\hline (B) & $\begin{array}{l}\text { SSWI estimated that } 75 \text { percent of the commercial corrugated was collected in Pigeon Forge. One-half of the } \\
\text { remaining } 25 \text { percent was assumed to come from Sevierville. }\end{array}$ \\
\hline (h) & Includes drop-off recyclables and commercial corrugated. \\
\hline [i] & Includes garbage and sludge/grease less bypass waste. \\
\hline [i] & $\begin{array}{l}\text { Based on information in Regional Plan assumed to be } 10 \text { percent by weight of demolition waste excluding } \\
\text { tires. }\end{array}$ \\
\hline [k] & $\begin{array}{l}\text { Estimated based on total county ferrous tonnages by assuming quantities are proportional to demolition waste } \\
\text { quantities excluding tires. }\end{array}$ \\
\hline (I) & Data not available to estimate but assumed to be negligible \\
\hline [m] & Commercial comgated is baled in recycling warehouse. \\
\hline [n] & Total does not equal Generation Total due to materials bypassing processing programs. \\
\hline [o] & Based on Bedminster records and assuming compost is proportional to total waste composted. \\
\hline IP] & Estimated based on total county bypass tonnages by assuming quantities are proportional to garbage quantities. \\
\hline [\$] & $\begin{array}{l}\text { Estimated based on total county residue tonnages by assuming quantities are proportional to composted } \\
\text { tonnages. }\end{array}$ \\
\hline (i) & Equal to total demolition waste quantity less materials removed from demolition waste at Class IV landfill \\
\hline [a] & Includes woodwaste and ferrous recovered at Class IV landfill. \\
\hline 111) & $\begin{array}{l}\text { Estimated based on total county ferrous tonnages by assuming quantities are proportional to composted } \\
\text { garbage tonnages. }\end{array}$ \\
\hline (u) & Total does not equal Generation Total due to processing loss (primarily moisture loss during composting). \\
\hline
\end{tabular}

The amount of the total waste stream that was diverted from landfill disposal through the SSWI programs during FY $1993 / 94$ was 43,500 tons or 60 percent by weight, which can be broken down as follows:

- The amount recovered for recycling or reuse (newspaper, corrugated, aluminum, plastics, used oil, ferrous from the Class IV landfill and composting facility, and wood waste) was approximately 2,100 tons or 3 percent by weight of the total waste stream;

- The amount stockpiled was approximately 400 tons of tires or less than one percent by weight of the total waste stream; and

- The amount diverted through composting was 41,100 tons (excluding ferrous recovery) or 57 percent by weight of the total waste stream ( 60,338 tons composted less 18,768 tons of composting residue less 496 tons of recovered ferrous equals 41,074 tons diverted).

The amount of Sevierville's waste stream that was diverted from landfill disposal through the SSWI programs during FY 1993/94 was 8,400 tons or 61 percent by weight, which can be broken 
down as follows:

- The amount recovered for recycling or reuse (newspaper, corrugated, aluminum, plastics, used oil, ferrous from the Class IV landfill and composting facility, and wood waste) was approximately 350 tons or 3 percent by weight of the total waste stream;

- The amount stockpiled was approximately 150 tons of tires or 1 percent by weight of the total waste stream; and

- The amount diverted through composting was 7,900 tons (excluding ferrous recovery) or 57 percent by weight of the total waste stream $(11,621$ tons composted less 3,615 tons of composting residue less 100 tons of recover ferrous equals 7,906 tons diverted).

\subsection{Compost Facility}

During FY 1993/94, the compost facility processed garbage from within the County along with grease and sewage sludge from inside and outside the County. Based on scale house records, approximately 51,000 tons of garbage and 4,500 tons of grease and sludge generated within the County and 5,600 tons of sludge imported from outside the County were delivered for composting at the SSWI site (including waste which eventually bypassed the composting facility due to capacity limitations) during FY 1993/94. Therefore, the total amount of waste delivered for composting (including bypass waste) was approximately 61,100 tons.

Of the garbage delivered for composting (including waste which eventually bypassed the composting facility due to capacity limitations), scalehouse records show approximately 10,300 tons ( 20 percent by weight) were from Sevierville. The amount of grease and sludge delivered by Sevierville was approximately 1,500 tons, 15 percent by weight of the total sludge and grease delivered for composting. In total, 11,800 tons of garbage, grease, and sludge from Sevierville were delivered to the SSWI site for composting (including bypass waste) or 19 percent of the total county waste delivered for composting.

A comparison of records from Bedminster on quantities of compost residue and scalehouse records on the total amount of waste (residue and bypass) disposed of in the Class I landfills during FY 1993/94 indicates approximately 800 tons of the garbage delivered for composting bypassed the compost facility because the facility was already running over capacity. Otherwise, all garbage, sludge, and grease delivered to the SSWI site were composted. Based on the estimated bypass tonnage for the whole county and assuming bypassed amounts of garbage are proportional to the amounts delivered for composting, it is estimated that less than 200 tons of the bypass waste were from Sevierville. For both the total County and Sevierville, the bypass waste was about 1 percent of the garbage delivered to the SSWI facilities.

Bedminster records show approximately 18,800 tons of residue were produced by the compost facility during FY 1993/94. Based on this total residue amount from the facility and assuming residue quantities are proportional to quantities of waste composted, the estimated residue produced as a result of composting Sevierville's waste is 3,600 tons or 19 percent of the total composting residue.

Scalehouse records from the SSWI site indicate that about 500 tons of ferrous were recovered 
from the garbage processed by the composting facility or 100 tons from Sevierville's garbage (assuming the amounts of ferrous recovered are proportional to the amounts of garbage processed). In both cases, these recovered ferrous quantities are equal to about one percent by weight of the composted garbage.

Bedminster records show approximately 15,300 tons of compost were produced and marketed during FY 1993/94. The amount of compost produced from Sevierville's garbage, grease, and sludge processed at the compost facility was estimated to be 2,900 tons or 19 percent of the total compost produced. This estimate was made based on the total amounts of compost produced at the facility by assuming that compost quantities are proportional to the amount of waste composted.

The compost facility diverted a total of 41,600 tons of waste (including ferrous), including 8,000 tons of Sevierville waste, from landfill disposal. This equates to approximately a 70 percent reduction in weight of the garbage, sludge and grease processed in the composting facility (as compared to the total estimated waste stream reduction of approximately 60 percent for the entire system as detailed earlier in this section).

\subsection{Class I Landfills}

During FY 1993/94, the Class I landfills were utilized to dispose of residue and bypass waste from the compost facility. Scale house records indicate approximately 19,600 total tons of bypass waste and residue from the compost facility were disposed of in these landfills. As discussed above, this is assumed to include approximately 800 tons of bypass garbage and 18,800 tons of compost facility residue.

The estimated amount of bypass waste and composting facility residue resulting from the management of Sevierville waste was identified above as 200 tons and 3,600 tons, respectively, for a total of approximately 3,800 tons. For both the total County and Sevierville, the amount of materials disposed of in the Class I landfills during FY 1993/94 is estimated to be 96 percent by weight residue and 4 percent bypass waste.

\subsection{Class IV Landfill}

During FY 1993/94, the Class IV landfill received construction and demolition waste, tires, and other bulky wastes. Ferrous metals, wood waste (including pallets) and tires were recovered from this bulky waste at the landfill site and the balance was disposed in the landfill.

Scalehouse records show that a total of 10,700 tons of demolition waste were delivered to SSWI facilities during FY 1993/94. Of this amount, approximately 1,900 tons or 18 percent by weight were from Sevierville.

Scalehouse records indicate approximately 360 tons of the demolition waste delivered to the Class IV landfill were tires which were shredded and stockpiled during FY 1993/94. Of this total amount of tires, 150 tons or 42 percent by weight were from Sevierville.

Data on the quantities of wood waste recovered at the Class IV landfill during FY 1993/94 are 
not available. Therefore, estimates of the quantities recovered were made based on information in the Regional Plan which estimated that 10 percent of the demolition waste (exclusive of tires) is recovered as mulched wood waste. Therefore, it was estimated on a County-wide basis that approximately 1,000 total tons of wood waste were mulched during FY 1993/94. The quantity of wood waste from Sevierville that was mulched was estimated at approximately 180 tons. Data on the quantities of wood pallets recovered at the landfill are not available but were assumed to be negligible.

Approximately 80 tons of ferrous recovered were recovered at the Class IV landfill during FY $1993 / 94$ based on records from the intermediate processor which purchased it. The quantity of ferrous recovered from Sevierville's demolition waste was estimated to be about 10 tons based on the total quantity recovered assuming the recovered ferrous quantities were proportional to the amount of demolition waste (exclusive of tires) delivered to the SSWI facilities.

The balance of the bulky waste delivered to the Class IV facility not recovered was disposed of in the landfill. An estimated total of 9,200 tons of demolition waste were disposed of in the Class IV landfill during FY 1993/94. Of this amount, 1,600 tons or 17 percent by weight were from Sevierville.

The total amount of demolition waste diverted from disposal through recovery and stockpiling programs at the Class IV site during FY 1993/94 was 1,470 tons. The amount recovered from Sevierville demolition waste was estimated to be 340 tons. These amounts are equivalent to approximately 14 percent by weight of the total demolition waste and 18 percent of Sevierville's demolition waste delivered.

\subsection{Recyclables Drop-off and Commercial Corrugated Programs}

SSWI estimates approximately 220 tons of newspaper, glass, and plastic were collected during FY $1993 / 94$ at the six drop-off locations in the County. Data on the quantity collected from Sevierville is not available; however, the majority of the drop-off recyclables reported come from the residential sector. Therefore, it was assumed that the relative quantity of recyclables collected from Sevierville through the drop-off program is proportional to population. This resulted in an estimated quantity of about 30 tons of recyclables being collected at the drop-off sites from Sevierville.

Scale house records indicate about 240 tons of commercial OCC were collected and baled by SSWI during FY 1993/94. SSWI estimates that 75 percent of this came from businesses in Pigeon Forge with the balance from Gatlinburg and Sevierville. One-half of the remaining 25 percent was assumed to come from Sevierville. This resulted in an estimated quantity of about 30 tons of commercial OCC coming from Sevierville during FY 1993/94.

The amount of materials diverted from disposal through the recyclables drop-off program and commercial corrugated program represented less than 1 percent by weight of the total amount of materials diverted for both Sevierville and the entire County. 


\subsection{HHW (Used Motor Oil) Program}

SSWI estimates that approximately 2,700 gallons of used motor oil were collected through the eleven drop-off sites in the County during FY 1993/94. This volume was converted to tons assuming used motor oil has a density of 54.9 pounds per cubic foot which resulted in a total of 10 tons. The amount collected from Sevierville was estimated to be approximately one ton based on the relative population of Sevierville to the total County.

\subsection{Recovered Materials and Compost Markets}

Table 3-4 shows the intermediate processors, remanufacturers, and reusers for the recovered materials from the County's waste stream. The total quantity of these recovered materials and compost during FY 1993/94 was 17,300 tons of which an estimated 3,300 tons or 19 percent by weight originated in Sevierville's waste stream. Residue quantities from intermediate processors and end-users related to processing/utilizing these materials were not taken into account in this analysis. 
Table 3-4. Markets for Recovered Materials and Compost in FY 1993/94

\begin{tabular}{|c|c|c|c|c|c|c|c|c|c|c|c|}
\hline \multirow[b]{2}{*}{$\begin{array}{c}\text { Recovered } \\
\text { Material } \\
\end{array}$} & \multirow[b]{2}{*}{$\begin{array}{c}\text { Total } \\
\text { Tonnage }\end{array}$} & \multirow[b]{2}{*}{$\begin{array}{c}\text { City } \\
\text { Tonnage }\end{array}$} & \multicolumn{4}{|c|}{ Intermediate Processing } & \multicolumn{5}{|c|}{ Remanufacturing/End-Usage } \\
\hline & & & Processor & Location & $\begin{array}{c}\begin{array}{c}\text { Distance } \\
\text { from } \\
\text { SSWI site } \\
\text { (miles) }\end{array} \\
\end{array}$ & $\begin{array}{c}\text { Mode of } \\
\text { Transport } \\
\text { to } \\
\text { Processor } \\
\end{array}$ & $\begin{array}{c}\text { Remanufacturer/ } \\
\text { End-user }\end{array}$ & Location & $\begin{array}{c}\text { Distance } \\
\text { from } \\
\text { Processing } \\
\text { site (mi) }\end{array}$ & $\begin{array}{l}\text { Mode of } \\
\text { Transport } \\
\text { to end/use }\end{array}$ & End Use \\
\hline $\begin{array}{l}\text { Newspaper from } \\
\text { Drop-offs }\end{array}$ & $220^{[a]}$ & $31^{|a|}$ & $\begin{array}{l}\text { Lakeway } \\
\text { Recycling }\end{array}$ & $\begin{array}{l}\text { Morristown, } \\
\text { TN }\end{array}$ & 40 & $\begin{array}{l}\text { Roll-off } \\
\text { truck }\end{array}$ & Bowater & Calhoun, TN & 115 & $\begin{array}{l}\text { Tractor- } \\
\text { trailer }\end{array}$ & Newsprint \\
\hline $\begin{array}{l}\text { Aluminum from } \\
\text { Drop-offs }\end{array}$ & & & $\begin{array}{l}\text { Lakeway } \\
\text { Recycling }\end{array}$ & $\begin{array}{l}\text { Morristown, } \\
\text { TN }\end{array}$ & 40 & $\begin{array}{l}\text { Roll-off } \\
\text { truck }\end{array}$ & Alcoa & $\begin{array}{l}\text { Maryville, } \\
\text { TN }\end{array}$ & 55 & $\begin{array}{l}\text { Tractor- } \\
\text { trailer }\end{array}$ & Can Sheet \\
\hline $\begin{array}{l}\text { Plastics from } \\
\text { Drop-offs }\end{array}$ & & & $\begin{array}{l}\text { Lakeway } \\
\text { Recycling }\end{array}$ & $\begin{array}{l}\text { Morristown, } \\
\text { TN }\end{array}$ & 40 & $\begin{array}{l}\text { Roll-off } \\
\text { truck }\end{array}$ & Varies & Varies & Varies & $\begin{array}{l}\text { Tractor- } \\
\text { trailer }\end{array}$ & Varies \\
\hline $\begin{array}{l}\text { Commercial } \\
\text { OCC }\end{array}$ & 244 & 31 & SSWI & $\begin{array}{l}\text { SSWI Site } \\
\text { Recycling } \\
\text { Warehouse } \\
\end{array}$ & 0 & Not Appl. & Rock-Tenn & $\begin{array}{l}\text { Chattanooga, } \\
\text { TN }\end{array}$ & 130 & $\begin{array}{l}\text { Tractor- } \\
\text { trailer }\end{array}$ & Boxboard \\
\hline Compost & 15,248 & 2,937 & SSWI & $\begin{array}{l}\text { SSWI Site } \\
\text { Composting } \\
\text { Facility } \\
\end{array}$ & Not Appl. & Not Appl. & Varies & Varies & Varies & $\begin{array}{l}\text { Not } \\
\text { available }\end{array}$ & $\begin{array}{l}\text { Soil } \\
\text { amendment }\end{array}$ \\
\hline Used Motor Oil & 10 & 1 & Industrial Oil & $\begin{array}{l}\text { Knoxville, } \\
\text { TN }\end{array}$ & 25 & Unknown & Unknown & Unknown & Unknown & $\begin{array}{l}\text { Not } \\
\text { available }\end{array}$ & Unknown \\
\hline $\begin{array}{l}\text { Ferrous from } \\
\text { Compost Facility }\end{array}$ & 496 & 100 & $\begin{array}{l}\text { Southern } \\
\text { Alloy } \\
\end{array}$ & $\begin{array}{l}\text { Rockwood, } \\
\text { TN }\end{array}$ & 80 & $\begin{array}{l}\text { Tractor- } \\
\text { trailer }\end{array}$ & Varies & Varies & Varies & $\begin{array}{l}\text { Rail, truck } \\
\text { and barge }\end{array}$ & $\begin{array}{l}\text { Steel } \\
\text { Product }\end{array}$ \\
\hline $\begin{array}{l}\text { Ferrous from } \\
\text { Class IV } \\
\text { Landfill } \\
\end{array}$ & 77 & 13 & $\begin{array}{l}\text { Morristown } \\
\text { Shredders }\end{array}$ & $\begin{array}{l}\text { Morristown, } \\
\text { TN }\end{array}$ & 40 & $\begin{array}{l}\text { Roll-of } \\
\text { truck }\end{array}$ & Florida Steel & $\begin{array}{l}\text { Knoxville, } \\
\text { TN }\end{array}$ & 40 & $\begin{array}{l}\text { Tractor- } \\
\text { trailer }\end{array}$ & Steel Rebar \\
\hline Wood Pallets & Neg. & Neg. & Not Appl. & Not Appl. & Not Appl. & Not Appl. & $\begin{array}{l}\text { Newsport Pallet } \\
\text { (reuser) }\end{array}$ & $\begin{array}{l}\text { Newsport, } \\
\text { TN }\end{array}$ & 40 & $\begin{array}{l}\text { Not } \\
\text { available }\end{array}$ & Pallets \\
\hline $\begin{array}{l}\text { Wood waste } \\
\text { mulch }\end{array}$ & 1,035 & 176 & Not Appl. & Not Appl. & Not Appl. & Not Appl. & Local Residents & $\begin{array}{l}\text { Sevier } \\
\text { County } \\
\end{array}$ & Varies & $\begin{array}{l}\text { Not } \\
\text { available }\end{array}$ & Mulch \\
\hline Total & 17,330 & 3,289 & & & & & & & & & \\
\hline
\end{tabular}

Note:

III Data not available to break out total drop-off tonnages between materials. 


\section{Cost of Municipal Solid Waste Management}

The cost of MSW management (i.e., collection, procẹssing, and dispoșition) for Sevierville's waste is presented in this section.

Section 4.1 defines that portion of the waste stream for which collection costs are known (Analyzed MSW). Section 4.2 presents the total costs incurred by SSWI and Sevierville for management of their waste streams. Section 4.3 discusses how portions of the total costs are allocated to Analyzed MSW and then allocates those costs by functional area. Analyzed MSW costs are allocated by type of MSW (garbage and commercially-generated OCC) in Section 4.4, and program incremental costs are provided in Section 4.5. Finally, Section 4.6 provides a summary of the cost analysis results.

\subsection{Apportionment of Waste Stream}

Only a portion of the total solid waste streams described in Section 3, Municipal Solid Waste Quantities, are included in the economic analyses presented in this section. The reason for limiting the tonnage included in the analysis is to include only that portion of the waste streams considered to be MSW and for which the total cost of collection, processing, composting and disposal is known (i.e., Analyzed MSW). Failure to limit the economic analysis to the tonnage and costs associated with Analyzed MSW would bias the results and could result in misleading conclusions.

The Analyzed MSW presented in this section excludes self-hauled recyclables and HHW (used motor oil) collected through the drop-off collection system and garbage delivered into the SSWI system by private or self-haulers. The cost of collecting this excluded portion of the waste stream is not known and cannot be reasonably estimated within the scope of this study. Thus, both the costs and quantities are excluded from the economic analysis.

Sevierville provides separate collection of demolition wastes (including bulky wastes such as white goods and furniture, tires, construction demolition debris, and other wood wastes), which is transported to SSWI's Class IV demolition landfill for processing and disposal. The definition of MSW specifically excludes construction and demolition wastes, but typically does include bulky wastes. Since there is no information available on which to allocate the tonnages between demolition and bulky wastes, each of these waste stream components must be analyzed on an aggregate basis. In addition, collection cost data are not available from Sevierville. Therefore, since the majority of materials comprising demolition waste are not included in the definition of Analyzed MSW, and collection cost data are not available, an analysis of the costs incurred by Sevierville for management of demolition waste (including bulky waste) is not included in this study.

Sludge and grease are not considered MSW, and therefore, are excluded from Analyzed MSW. However, sludge and grease are a necessary "supply" to the composting facility. Therefore, the tonnages of sludge and grease processed at the composting facility are excluded from Analyzed MSW, but the costs associated with processing sludge and grease are included in the economic analyses.

Table 4-1 shows the FY 1993/94 tonnages of the components of both the total MSW and Analyzed MSW. 
Table 4-1. City of Sevierville FY 1993/94 Total Waste and Analyzed MSW Tonnages by Component

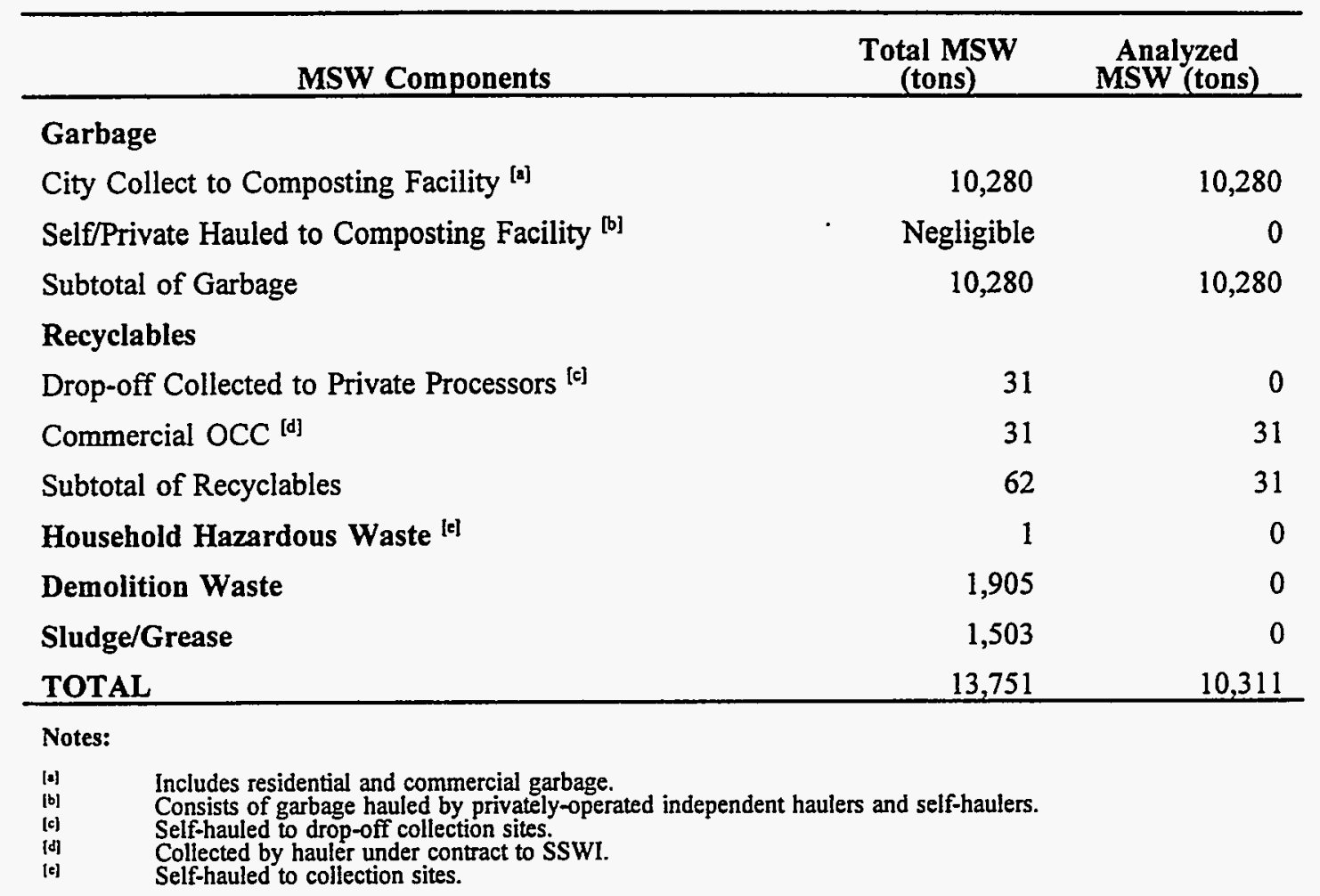

\subsection{Total Costs of Waste Management}

In order to determine gross and net costs attributable to Analyzed MSW, it was first necessary to determine the SSWI's and Sevierville's total costs for managing the waste streams discussed in Section 3, Municipal Solid Waste Quantities.

The gross and net costs were determined by performing the following steps:

- Determining the SSWI's total reported costs and revenues;

- Adjusting SSWI's total reported costs and revenues as necessary to satisfy the requirements of this study;

- Determining Sevierville's municipal collection costs;

- $\quad$ Estimating the costs of garbage containers (plastic bags, trash cans, and other containers) used to collect garbage, which are purchased by residents and businesses; and

- Combining SSWI adjusted costs and revenues, Sevierville costs, and costs of containers.

Appendix D, Capital Cost Calculations, provides a detailed explanation of the preceding steps. 


\subsubsection{SSWI Reported and Adjusted Costs}

- Detailed cost and revenue data for the SSWI was provided by SSWI's auditor. Table 4-2 presents a summary of the these costs and revenues. Table C-1 in Appendix C, Methodology and Data Used to Calculate Total Gross and Net Costs, provides additional detail on these reported and adjusted costs.

As shown in Table 4-2, capital costs are treated as "annualized capital costs" in the Adjusted Costs, whereas they are treated as "depreciation" and "amortization" costs in the Reported Costs column. The approach used in this analysis to calculate capital costs is to "annualize" or "capitalize" capital outlays over the useful life of the asset using a cost of capital of 7 percent. Assets older than useful life were assigned no annualized capital cost. Using this approach, the capital cost of an asset is independent of the method used to pay for the asset and has the same annual value over the useful life of the asset. More information on the methodology and assumptions used to estimate the "annualized capital costs" is provided in Appendices C and D.

Revenues received by SSWI include tipping fees, bond and interest assessments (paid by Gatlinburg, Pigeon Forge, Sevierville, and the County as members of SSWI), rental income from homes purchased as part of the acquisition of land for the Class IV landfill, revenues from the sale of recyclables (commercial OCC and ferrous recovered from the demolition waste and composting facility), and other miscellaneous income.

In accordance with the methodology established for use in these SWANA case studies, the only types of revenues considered in this analysis are those paid to SSWI for the sale of recyclables materials and compost recovered through SSWI programs. Other revenues such as tipping fees paid to SSWI, fees paid by local governments for use of the SSWI facilities, and funds used by Sevierville for providing garbage and demolition waste collection service are not included. Therefore, the reported income shown in Table 4-2 includes revenues from the sale of commercial OCC and ferrous recovered from demolition waste, and excludes all other income. The adjusted costs also include revenues received from the sale of ferrous recovered at the compost facility, which accrue to Bedminster, and therefore, are not accounted for in SSWI's financial statements. Based on data from Bedminster, the net revenues received from the sale of compost were assumed to be negligible. The adjusted revenues shown in Table 4-2 can be broken down as follows:

- $\quad$ Ferrous recovered at Class IV landfill:

$\$ 2,844$

Commercial OCC:

$\$ 8,974$

Ferrous recovered at composting facility:

$\$ 6,300$

Compost:

$\$ \quad 0$

Total

$\$ 18,117$

Other adjustments made to SSWI reported costs include:

- Operating costs were increased to include labor cost for the scale house operator, who is paid by the County (not SSWI); and

- Capital costs for the composting facility were also adjusted to account for composting 
Table 4-2. SSWI Revenues and Expenses Year Ending, June 30, 1994

\begin{tabular}{|c|c|c|}
\hline & $\begin{array}{c}\text { Reported } \\
\text { Revenues/ } \\
\text { (Expenses) }\end{array}$ & $\begin{array}{l}\text { Adjusted } \\
\text { Revenues/ } \\
\text { (Expenses) }\end{array}$ \\
\hline \multicolumn{3}{|l|}{ OPERATING INCOME: } \\
\hline Recyclables and Compost Revenue & $\$ 11,817^{\text {[b] }}$ & $\$ 18,117^{\text {lc] }}$ \\
\hline Total Operating Revenue & $\underline{11,817}$ & 18,117 \\
\hline \multicolumn{3}{|l|}{ OPERATING EXPENSES: } \\
\hline Personnel Cost & $\$ 289,180$ & $\$ 322,815^{[\mathrm{d}]}$ \\
\hline Supplies & 15,161 & 15,161 \\
\hline Maintenance & 68,576 & 68,576 \\
\hline General Services & 159,919 & 159,919 \\
\hline Landfill Closure/Post Closure Costs & 530,740 & $530,740^{[e]}$ \\
\hline Other & 48,864 & 48,864 \\
\hline Recycling Expenses & 41,022 & 41,022 \\
\hline Composting Expenses & 956,354 & 962,654 [f] \\
\hline Total Operating Expenses & $\$ 2,109,816$ & $\$ 2,149,751$ \\
\hline \multicolumn{3}{|l|}{ Net Operating Income (loss) before } \\
\hline Depreciation and Amortization & $(\$ 2,097,999)$ & $(\$ 2,131,634)$ \\
\hline Less Depreciation & 615,608 & 0 \\
\hline Less Amortization & 18,521 & 0 \\
\hline Annualized Cost Capital & 0 & $1,301,981^{[8]}$ \\
\hline NET OPERATING INCOME (LOSS) & $(\$ 2,732,128)$ & $(\$ 3,433,615)$ \\
\hline \multicolumn{3}{|l|}{ NON-OPERATING INCOME (EXPENSE): } \\
\hline Investment Income & $\$ 20,512$ & 0 \\
\hline Bond Interest Expense & $(572,471)$ & 0 \\
\hline Total Non-operating Income (Expense) & $(\$ 551,959)$ & $\underline{\mathbf{0}}$ \\
\hline NET INCOME (LOSS) & $(\$ 3,284,087)$ & $(\$ 3,433,615)$ \\
\hline
\end{tabular}

Notes:

[a] Source: SSWI's "Financial Statements, June 30, 1994 and 1993." Types of reported costs and revenues used in this study are consistent with those used in other case studies performed by CSI.

b] Other revenues consist of recycling revenues and miscellaneous income. Revenue shown represents recycling revenues only $(\$ 8,974$ for $O C C$ and $\$ 2,844$ for ferrous recovered at the Class IV landfill). Miscellaneous income was taken out.

[c] Adjusted to account for revenues $(\$ 6,300)$ from ferrous sales from the composting facility.

[d] Reflects $\$ 33,635$ adjustment for scale house operator.

[e] Due to a lack of information, these costs were not calculated using the methodology developed by CSI in the other case studies.

In Note [c] adjusted the operating income to account for $\$ 6,300$ in ferrous revenue for ferrous recovered by Bedminster at the compost facility. This adjustment shows the $\$ 6,300$ as an increased cost to SSWI.

[8] Reflects substitution of annualized capital costs for depreciation/amortization and net non-operating expenses. Line item is comprised of the following:

\section{Description}

Annualized Class I, Phase IVA Capital Costs Annualized Additional Composting Facility Capital Costs Annualization of Reported Amortization Items Annualization of Reported Depreciation Items

TOTAL

**Estimate provided by Bedminster (not documented).
Annualized Capital Costs

$\$ 130,000$

$\$ 113,277^{* *}$

$\$ 33,798$

$\underline{\$ 1,024,906}$

$\$ 1,301,981$ 
facility costs incurred by Bedminster, and therefore, are not shown in SSWI financial statements.

\subsubsection{City Reported Costs}

Sevierville's Department of Sanitation is responsible for the day-to-day collection of residential and commercial garbage within Sevierville. However, many services, such as vehicle and equipment maintenance, and other general and administrative (G\&A) services, such as support services, are provided by other Sevierville departments. Since garbage collection in Sevierville is paid for from general revenues and is not treated as an enterprise system, a consolidated accounting of the costs of collection is not available. Instead, R. W. Beck determined the total cost of collection by compiling information provided by Sevierville and making estimates and assumptions when needed.

Table 4-3 shows an itemized breakdown of the actual FY 1993/94 expenditures for garbage collection in Sevierville. The majority of the costs for collection are paid from Sevierville's Sanitation Fund. However, some costs for repairing and maintaining Sevierville's collection fleet are paid for from Sevierville's Garage Fund and not the Sanitation Fund. All Sevierville vehicles use the Sevierville garage. Based on discussions with Sevierville staff, 10 percent of the actual expenditures incurred by the Sevierville garage were allocated to the Sanitation Department, which adds an additional cost of $\$ 7,435$.

Table 4-3. Total Gross Sevierville Cost of Collection (FY 1993/94 \$)

\begin{tabular}{lr}
\hline Sanitation Fund & \\
City Garage & $\$ 229,147$ \\
Vehicle Annualized Capital Costs & 7,435 \\
G\&A & 81,839 \\
TOTAL & 63,684 \\
\hline
\end{tabular}

The Sanitation Fund does not include the cost of capitalized assets. Therefore, a list of the collection vehicles used by Sevierville was obtained from Sevierville. This list included original purchase prices and dates of purchase. An annualized capital cost expense was determined for the vehicles using the procedures described in Appendix D, Capital Cost Calculations. The calculation of the annual capital cost assumed a 7 percent cost of capital and a useful life of five years. The resulting associated annualized cost of the vehicles was $\$ 81,839$. Additional information on the inputs and methodology used to derive this number is provided in Appendix C, Methodology and Data Used to Calculate Total Gross and Net Costs.

R. W. Beck assumed that G\&A expenses would be approximately 20 percent of the total costs based on professional judgement and a review of Sevierville's total budget in relation to the cost of collection. 


\subsubsection{Costs of Bags, Cans, and Containers}

In addition to the expenses incurred by Sevierville and SSWI, individuals and businesses incur the costs of plastic bags, garbage cans, and containers used in garbage collection. Since a dropoff program is used in Sevierville for recyclables collection, it is reasonable to assume that containment costs to the residents is minimal. However, SSWI provides for the containers used in the commercial OCC collection program and this cost was reflected in the analysis of SSWI's costs. Therefore, the cost of using bags, cans, and containers must be included in the cost of managing garbage. Using the methodology developed for the other previous case studies, the cost of containment for garbage can be determined, as follows.

The estimated costs of bags, cans, and containers is determined by multiplying the cost per bag, can, or container by the number of each used. Plastic bags are not reusable and are, therefore, consumed when the garbage is picked up. On the other hand, trash cans and containers are capital goods. Furthermore, many people use both plastic bags and either cans or containers, i.e., the plastic bag is used in the garbage can and plastic bags of garbage are thrown into the garbage containers at businesses. To estimate these costs, the following assumptions were used, consistent with previous case studies:

- For residential and commercial curbside garbage collection, 65 percent of all customers use plastic bags and 70 percent of customers use garbage cans;

- For commercial dumpster collection, 65 percent of all customers use bags;

- A 30-gallon plastic bag and 30-gallon garbage can hold approximately 0.149 cubic yards or 0.011 tons of garbage;

- The average cost of a 30 -gallon plastic bag is about $\$ 0.13$;

- The average cost of a 30-gallon garbage can is $\$ 20$, and the average cost of a commercial dumpster is $\$ 500$; both have a useful life of 10 years; and

- The cost of capital is 7 percent.

Using the above assumptions, the estimated cost of bags, cans, and containers for the collection of garbage in Sevierville is $\$ 95,038$.

\subsubsection{Combined Costs and Revenues}

The combined SSWI adjusted costs and revenues, Sevierville costs, and costs of containers result in the total gross and net costs shown in Table 4-4. 
Table 4-4. Total Gross and Net Costs of IMSWMS (FY 1993/94 \$)

\begin{tabular}{lrr}
\hline & \multicolumn{1}{c}{ Gross } & \multicolumn{1}{c}{ Net } \\
\hline SSWI & $\$ 3,451,732$ & $\$ 3,433,615$ \\
Sevierville Municipal Collection & 382,106 & 382,106 \\
Bag/Can/Container Costs & 95,038 & 95,038 \\
TOTAL & $\$ 4,075,227$ & $\$ \mathbf{\$ 4 , 0 5 7 , 1 1 0}$ \\
\hline
\end{tabular}

\subsection{Total Costs of Analyzed MSW Management and Costs by Functional Area}

In order to allocate the gross and net costs shown in Table 4-4, which are attributable to managing 10,311 tons of Analyzed MSW, R. W. Beck first allocated costs into the following functional areas:

- Collection;

- Class I landfill;

- Class IV landfill;

- $\quad$ OCC recycling (processing);

- $\quad$ Composting facility;

- $\quad$ Tire shredding;

- Wood grinding;

- General and administrative; and

- Other.

All types of costs incurred by the SSWI and Sevierville were reviewed by R. W. Beck and allocated to one of the specific functional areas shown above. Then it was determined whether each cost could be classified as being either "applicable" or "not applicable" to Analyzed MSW. Tonnage figures were used when necessary to determine the portion of total costs that should be allocated to Analyzed MSW. Additional detail is provided on the resulting costs in Appendix B, Allocation of Gross Costs and Result Tables. Table 4-5 presents the results of this allocation of gross costs on a functional basis and the amount of the gross costs determined to be attributable to Analyzed MSW. In total, the estimated gross cost for managing Analyzed MSW is $\$ 1,094,643$.

The amounts of revenues received by SSWI from the sale of compost and recyclables were next analyzed to determine the portion that should be attributed to Analyzed MSW. Tonnage figures were used when necessary to determine the portion of total revenues that should be allocated to Analyzed MSW. Table 4-6 presents the results of this allocation of revenues on a functional basis and the amount of the revenues determined to be attributable to Analyzed MSW. In total, the estimated revenues attributable to Analyzed MSW are $\$ 2,410$.

Table 4-7 contains gross costs of managing Analyzed MSW by functional area. Table 4-8 contains net costs of managing Analyzed MSW by functional area after deducting revenues shown in Table 4-6 from gross costs shown in Table 4-5. 
Table 4-5. Total Gross Costs of Sevierville's IMSWMS Allocated by Functional Area (FY 1993/94\$)

\begin{tabular}{|c|c|c|c|c|c|c|c|c|c|c|c|c|}
\hline Description & $\begin{array}{c}\text { Garbage } \\
\text { Collection }\end{array}$ & $\begin{array}{c}\text { Class I } \\
\text { Landfill }\end{array}$ & $\begin{array}{l}\text { Class IV } \\
\text { Landfill }\end{array}$ & $\begin{array}{l}\text { Corrugated } \\
\text { Recycling } \\
\text { Processing }\end{array}$ & $\begin{array}{l}\text { Corrugated } \\
\text { Recycling } \\
\text { Collection }\end{array}$ & $\begin{array}{c}\text { Other } \\
\text { Recycling }\end{array}$ & $\begin{array}{c}\text { Composting } \\
\text { Facility }\end{array}$ & $\begin{array}{c}\text { Tire } \\
\text { Shredding }\end{array}$ & $\begin{array}{c}\text { Wood } \\
\text { Grinding }\end{array}$ & G\&A & Other & Total \\
\hline $\begin{array}{l}\text { SSWI Total } \\
\text { Operating } \\
\text { Expenses }\end{array}$ & 0 & 783,886 & 98,323 & 35,484 & 39,716 & 41,022 & 967,307 & 11,786 & 13,460 & 158,765 & 0 & $2,149,749$ \\
\hline $\begin{array}{l}\text { SSWI Total } \\
\text { Annualized } \\
\text { Capital Costs }\end{array}$ & 0 & 270,558 & 84,349 & 36,652 & 19,096 & 0 & 776,570 & 4,687 & 21,141 & 66,257 & 22,670 & $1,301,980$ \\
\hline $\begin{array}{l}\text { Total Costs - } \\
\text { Sevierville } \\
\text { Collection }\end{array}$ & 318,422 & 0 & 0 & 0 & 0 & 0 & 0 & 0 & 0 & 63,684 & 0 & 382,106 \\
\hline $\begin{array}{l}\text { Total Costs } \\
\text { Bag/Can } \\
\text { Containers } \\
\text { Costs }\end{array}$ & 95,038 & 0 & 0 & 0 & 0 & 0 & 0 & 0 & 0 & 0 & 0 & 95,038 \\
\hline $\begin{array}{l}\text { Total Gross } \\
\text { Cost }\end{array}$ & 413,460 & $1,054,444$ & 182,672 & 72,136 & 58,812 & 41,022 & $1,743,877$ & 16,473 & 34,601 & 288,706 & 22,670 & $3,928,873$ \\
\hline $\begin{array}{l}\text { Percent } \\
\text { "applicable" to } \\
\text { MSW } \\
\text { Analyzed }\end{array}$ & $100 \%$ & $20.14 \%$ & $0 \%$ & $12.7 \%$ & $12.7 \%$ & 0 & $20.14 \%$ & 0 & 0 & $34.97 \%$ & 0 & - \\
\hline $\begin{array}{l}\text { Total } \\
\text { "applicable" } \\
\text { gross cost for } \\
\text { MSW } \\
\text { Analyzed }\end{array}$ & 413,460 & 212,365 & 0 & 9,161 & 7,469 & 0 & 351,217 & 0 & 0 & 100,971 & 0 & $1,094,643$ \\
\hline
\end{tabular}


Table 4-6. Total Revenues of Sevierville's IMSWMS Allocated by Functional Area (FY 1993/94 \$)

\begin{tabular}{|c|c|c|c|c|}
\hline Description & $\begin{array}{l}\text { Class IV Landfill } \\
\text { Disposal \& } \\
\text { Materials Recovery }\end{array}$ & $\begin{array}{c}\text { Corrugated } \\
\text { Collection \& } \\
\text { Processing } \\
\end{array}$ & $\begin{array}{l}\text { Composting } \\
\text { Facility }\end{array}$ & Total \\
\hline $\begin{array}{l}\text { SSWI Total Revenues } \\
\text { from Sale of Ferrous } \\
\text { Recovered at Class IV } \\
\text { Landfill }\end{array}$ & $\$ 2,844$ & NA & NA & $\$ 2,844$ \\
\hline $\begin{array}{l}\text { SSWI Total Revenues } \\
\text { from Sale of Ferrous } \\
\text { Recovered at Composting } \\
\text { Facility }\end{array}$ & NA & NA & $\$ 6,300$ & $\$ 6,300$ \\
\hline $\begin{array}{l}\text { SSWI Total Revenues } \\
\text { from Sale of Compost }\end{array}$ & NA & NA & \$o & $\$ 0$ \\
\hline $\begin{array}{l}\text { SSWI Total Revenues } \\
\text { from Sale of Commercial } \\
\text { OCC }\end{array}$ & NA & $\$ 8,974$ & NA & $\$ 8,974$ \\
\hline Total SSWI Revenues & $\$ 2,844$ & $\$ 8,974$ & $\$ 6,300$ & $\$ 18,118$ \\
\hline $\begin{array}{l}\text { Percent "Applicable" to } \\
\text { Analyzed MSW }\end{array}$ & $0 \%$ & $12.7 \%$ & $20.2 \%$ & $13.1 \%$ \\
\hline $\begin{array}{l}\text { Total "Applicable" } \\
\text { Revenues to Analyzed } \\
\text { MSW }\end{array}$ & $\$ 0$ & $\$ 1,140$ & $\$ 1,270$ & $\$ 2,410$ \\
\hline
\end{tabular}

Table 4-7. Gross Costs of Managing Analyzed MSW by Functional Area (FY 1993/94 \$)

\begin{tabular}{lrrrr}
\hline \multicolumn{1}{c}{ Functional Area } & $\begin{array}{c}\text { Applicable Tons of } \\
\text { Analyzed MSW }\end{array}$ & \multicolumn{1}{c}{$\begin{array}{l}\text { Gross } \\
\text { Costs }\end{array}$} & \multicolumn{1}{c}{ \$/ton } & \multicolumn{1}{c}{$\begin{array}{c}\text { Percent of } \\
\text { Gross Costs }\end{array}$} \\
\hline Garbage Collection & & $\$ 413,460$ & $\$ 40.22$ & $38 \%$ \\
Composting Facility & 10,280 & 351,217 & 34.17 & $32 \%$ \\
Class I Landfill & & 212,365 & 20.66 & $19 \%$ \\
OCC Collection and & 31 & 16,630 & 536.45 & $2 \%$ \\
Processing & 10,311 & 100,971 & 9.79 & $9 \%$ \\
G\&A & 10,311 & $\mathbf{1 , 0 9 4 , 6 4 3}$ & $\mathbf{\$ 1 0 6 . 1 6}$ & $\mathbf{1 0 0 \%}$ \\
TOTAL & & & & \\
\hline
\end{tabular}


Table 4-8. Net Costs of Managing Analyzed MSW by Functional Area (FY 1993/94 \$)

\begin{tabular}{lrrrr}
\hline \multicolumn{1}{c}{ Functional Area } & $\begin{array}{c}\text { Applicable Tons of } \\
\text { Analyzed }\end{array}$ & \multicolumn{1}{c}{ Net Costs } & \multicolumn{1}{c}{ s/ton } & \multicolumn{2}{c}{$\begin{array}{c}\text { Percent of Net } \\
\text { Costs }\end{array}$} \\
\hline Garbage Collection & & $\$ 413,460$ & $\$ 40.22$ & $38 \%$ \\
Composting Facility & 10,280 & 349,947 & 34.04 & $32 \%$ \\
Class I Landfill & & 212,365 & 20.66 & $19 \%$ \\
$\begin{array}{l}\text { OCC Collection and } \\
\text { Processing }\end{array}$ & 31 & 15,490 & 499.68 & $1 \%$ \\
G\&A & 10,311 & 100,971 & 9.79 & $9 \%$ \\
TOTAL & $\mathbf{1 0 , 3 1 1}$ & $\mathbf{\$ 1 , 0 9 2 , 2 3 3}$ & $\mathbf{\$ 1 0 5 . 9 3}$ & $\mathbf{1 0 0 \%}$ \\
\hline
\end{tabular}

\subsection{Allocation of Analyzed MSW Management Costs by Type of Waste}

The procedure to allocate the $\$ 1,094,643$ total gross cost of managing the 10,311 tons of Analyzed MSW to the cost of managing garbage and OCC required only that G\&A expenses be allocated in direct proportion to the allocation of other costs (except collection costs). Table 4-9 shows the results of this allocation.

Table 4-9. Total Gross Costs of Sevierville's IMSWMS Allocated by Type of Waste (FY 1993/94 \$)

\begin{tabular}{lrrrr}
\hline \multicolumn{1}{c}{ Type of Waste } & $\begin{array}{c}\text { Total Gross Costs } \\
\text { (without G\&A) }\end{array}$ & Total G\&A & $\begin{array}{c}\text { Total Gross Costs } \\
\text { (with G\&A) }\end{array}$ & $\begin{array}{c}\text { Percent of Gross } \\
\text { Costs (with G\&A) }\end{array}$ \\
\hline Garbage & & & & \\
Collection & $\$ 413,460$ & $\$ 63,684$ & $\$ 477,144$ & $44 \%$ \\
Class I Landfill & 212,365 & 13,648 & 226,013 & $21 \%$ \\
Composting Facility & 351,217 & 22,571 & 373,788 & $35 \%$ \\
Subtotal & $\$ 977,042$ & $\$ 99,903$ & $\$ 1,076,945$ & $100 \%$ \\
Corrugated & & & & \\
Processing & $\$ 9,161$ & $\$ 589$ & $\$ 59,750$ & $45 \%$ \\
Collection & 7,469 & 480 & 7,949 & $100 \%$ \\
Subtotal & $\$ 16,630$ & $\$ 1,069$ & $\$ 17,699$ & NA \\
TOTAL & $\$ 993,672$ & $\$ 100,971$ & $\$ 1,094,643$ & \\
\hline
\end{tabular}

Table 4-10 shows the results of the cost allocation after taking into account revenues that are 
attributable to Analyzed MSW. Also shown in this table are percentage costs by functional area for each waste type and dollar per ton costs.

\subsection{Program Incremental Costs}

In this section, the estimated Program Incremental Costs of the OCC Recycling Program and Composting Facility Program are presented. A Program Incremental Cost (or Savings) is defined in these SWANA case studies as "the difference between the cost of managing MSW with and without the inclusion of a particular program."

The results of the Program Incremental Costs analysis are provided in Tables 4-11 and 4-12. Each table shows in the first column the costs incurred by Sevierville in FY 1993/94, which includes the costs of both the Programs (i.e., "With Program"). The second column of each table (i.e., "Without Program") shows an estimate of the costs (or savings) that would have occurred if a given Program had never been implemented. The difference between the first two columns is shown in the third column and represents the Program Incremental Cost (or Savings).

\subsubsection{OCC Recycling Program}

The FY 1993/94 estimated Program Incremental Costs for the OCC Recycling Program are about $\$ 14,741$, or $\$ 476$ per ton for the 31 tons recovered from Sevierville through this Program.

It is assumed that without the OCC Recycling Program, the G\&A costs would remain about the same partly because the OCC recovered accounts for less than 1 percent of the total Analyzed MSW and partly because unrecovered OCC would need to be handled at the Composting Facility or the Class I Landfill.

Without the OCC Recycling Program, the cost of collecting and processing the OCC would be eliminated. In addition, it is not anticipated that the cost of garbage collection would increase because the recovered OCC represents less than 1 percent of the Analyzed MSW.

The Class I Landfill costs would increase slightly to account for the landfilling of the residue resulting from the composting of the 31 tons of OCC. The Composting Facility costs would increase slightly to account for the increase in variable operating costs associated with composting the 31 tons.

\subsubsection{Composting Facility Program}

The FY 1993/94 estimated Program Incremental Costs for the Composting Facility Program are about $\$ 211,680$, or $\$ 21$ per ton for the 10,280 tons from Sevierville managed through this Program.

It is assumed that without the Program, the G\&A costs would remain about the same because the tons managed at the Composting Facility would need to be handled at the Class I Landfill.

Elimination of the Composting Facility Program would not affect either the OCC Recycling Program costs or garbage collection costs. Revenues for recovered materials would be reduced because the ferrous currently recovered at the Composting Facility would not be recovered. 
Table 4-10. Total Net Costs of Sevierville's City IMSWMS Allocated by Type of Waste (FY 1993/94\$)

\begin{tabular}{|c|c|c|c|c|c|c|c|}
\hline Type of Waste & $\begin{array}{c}\text { Total Gross } \\
\text { Costs (without } \\
\text { G\&A) }\end{array}$ & Total G\&A & $\begin{array}{l}\text { Total Gross Costs } \\
\text { (with G\&A) }\end{array}$ & Revenues & $\begin{array}{l}\text { Total Net } \\
\text { Costs (with } \\
\text { G\&A) }\end{array}$ & $\begin{array}{l}\text { Applicable } \\
\text { Tons of } \\
\text { Analyzed } \\
\text { MSW }\end{array}$ & $\begin{array}{c}\text { Net Costs } \\
\text { (with G\&A) } \\
\text { \$/tons }\end{array}$ \\
\hline \multicolumn{8}{|l|}{ Garbage } \\
\hline Collection & $\$ 413,460$ & $\$ 63,684$ & $\$ 477,144$ & $\$ 0$ & $\$ 477,144$ & \multirow{4}{*}{10,280} & $\$ 46.41$ \\
\hline Class I Landfill & 212,365 & 13,648 & 226,013 & 0 & 226,013 & & 21.99 \\
\hline Composting Facility & 351,217 & 22,571 & 373,788 & 1,270 & 372,518 & & 36.24 \\
\hline Subtotal & $\$ 977,042$ & $\$ 99,903$ & $\$ 1,076,945$ & $\$ 1,270$ & $\$ 1,075,675$ & & $\$ 104.64$ \\
\hline \multicolumn{8}{|l|}{ Corrugated } \\
\hline $\begin{array}{l}\text { Collection and } \\
\text { Processing }\end{array}$ & $\$ 16,630$ & $\$ 1,069$ & $\$ 17,699$ & $\$ 1,140$ & $\$ 16,559$ & 31 & $\$ 534.16$ \\
\hline Total & $\$ 993,672$ & $\$ 100,972$ & $\$ 1,094,643$ & $\$ 2,410$ & $\$ 1,092,234$ & 10,311 & $\$ 105.93$ \\
\hline
\end{tabular}


Table 4-11. Incremental Cost of OCC Recovery Program (FY 1993/94)1

\begin{tabular}{lrrr}
\hline \multicolumn{1}{c}{ Cost Categories and Revenúes } & $\begin{array}{c}\text { With } \\
\text { Program }\end{array}$ & $\begin{array}{c}\text { Without } \\
\text { Program }\end{array}$ & $\begin{array}{c}\text { Incremental Cost } \\
\text { (Savings) }\end{array}$ \\
\hline G\&A & 100,971 & 100,971 & 0 \\
OCC Collection & 7,469 & 0 & 7,469 \\
Garbage Collection & 413,460 & 413,460 & 0 \\
OCC Processing & 9,161 & 0 & 9,161 \\
Class I Landfill & 212,365 & 212,446 & $(81)$ \\
Composting Facility & 351,217 & 351,885 & $(668)$ \\
Revenues & $(2,410)$ & $(1,270)$ & $(1,140)$ \\
TOTAL & $\$ 1,092,233$ & $\$ \mathbf{\$ 1 , 0 7 7 , 4 9 2}$ & $\$ 14,741$ \\
Tons Managed & & & 31 \\
Incremental Cost Per Ton & & & $\$ 476$ \\
\hline
\end{tabular}

Table 4-12. Incremental Cost of the Composting Facility (FY 1993/94)

\begin{tabular}{lrrr}
\hline \multicolumn{1}{c}{ Cost Categories and Revenues } & \multicolumn{1}{c}{$\begin{array}{c}\text { With } \\
\text { Program }\end{array}$} & $\begin{array}{c}\text { Without } \\
\text { Program }\end{array}$ & $\begin{array}{c}\text { Incremental Cost } \\
\text { (Savings) }\end{array}$ \\
\hline G\&A & 100,971 & 100,971 & 0 \\
OCC Collection & 7,469 & 7,469 & 0 \\
Garbage Collection & 413,460 & 413,460 & 0 \\
OCC Processing & 9,161 & 9,161 & 0 \\
Class I Landfill & 212,365 & 350,632 & $(138,267)$ \\
Composting Facility & 351,217 & 0 & 351,217 \\
Revenues & $(2,410)$ & $(1,140)$ & $(1,270)$ \\
Total & $\$ 1,092,233$ & $\$ 880,553$ & $\$ 211,680$ \\
Tons Managed & & & 10,280 \\
Incremental Cost Per Ton & & & 21 \\
\hline
\end{tabular}

The Class I Landfill costs would increase to account for the landfilling of almost all garbage. It is estimated that personnel costs would double and annualized capital cost of the landfill would increase in proportion to the increase in tonnage.

The Composting Facility costs would be eliminated. 


\subsection{Summary of Results}

Of the approximately 72,000 tons of waste managed by SSWI, about 10,300 tons were analyzed to determine the cost of Sevierville's IMSWMS. The total FY 1993/94 net cost to manage the Analyzed MSW was about $\$ 1,092,000$, or $\$ 106$ per ton. This net cost, after taking into account G\&A expenses and revenues, was broken down in Table 4-9 by Analyzed MSW category as follows:

- Garbage:

- Commercial OCC:
98.5 percent ( $\$ 105$ per ton of garbage in Analyzed MSW)

1.5 percent ( $\$ 534$ per ton of OCC in Analyzed MSW)

As shown above, the cost for the management of commercial OCC on a per ton basis is very high when compared with garbage. However, the total costs for managing OCC are insignificant in comparison to those for garbage.

The net cost, after taking into account revenues, was also broken down by functional area in Table 4-7. The results are as follows:

- Garbage collection:

38 percent ( $\$ 40$ per ton of garbage in Analyzed MSW)

- $\quad$ Composting facility:

32 percent ( $\$ 34$ per ton of garbage in Analyzed MSW)

- Class I landfill:

19 percent (\$21 per ton of garbage in Analyzed MSW)

- Commercial OCC collection 1 percent ( $\$ 500$ per ton of OCC in Analyzed MSW) and processing:

- G\&A:

9 percent ( $\$ 10$ per ton of Analyzed MSW)

As shown above, garbage collection costs are the most significant factor in the total cost of Sevierville's IMSWMS, accounting for about 48 percent of the total net costs. The next largest cost is for the composting facility at 32 percent of the net costs.

The Program Incremental Costs analysis resulted in the following incremental costs per ton by program:

- Commercial OCC collection and processing:

$\$ 476$ per ton

- $\quad$ Composting facility:

$\$ 21$ per ton 


\section{Energy Usage Analysis}

The energy consumed to manage Analyzed MSW, as defined in Section 4.1, is discussed in this section. The amount of energy consumed is estimated by category of Analyzed MSW, type of energy consumed, and management program. Categories of Analyzed MSW include garbage and recyclables (commercial OCC). Types of energy consumed include diesel fuel, gasoline, and electricity. Types of management programs include:

- Garbage and commercial OCC collection;

- $\quad$ Composting facility operation;

- $\quad$ Class I landfill operation;

- Recycling warehouse operation; and

- Hauling commercial OCC and ferrous recovered at the composting facility to market.

Commercial OCC is hauled directly from the recycling warehouse to a remanufacturer. Estimated energy consumption for such hauling is included in the analysis but the energy consumed in the remanufacturing process is excluded because it is beyond the scope of this report. Since many remanufacturing processes which utilize recovered material use less energy than virgin material processes, this exclusion may understate the overall energy efficiency of recycling.

Ferrous recovered at the composting facility is hauled to an intermediate location where it is processed before shipment to remanufacturers. The intermediate processor reportedly sells materials to several steel mills in the South and uses several means of transportation (barge, truck, rail) to get the ferrous to the mills. Sufficient data was not available to estimate the energy consumed during intermediate processing of the ferrous and transportation to the remanufacturers. Therefore, the estimated energy consumption for transporting the ferrous to the intermediate processor is included, but energy consumption related to subsequent processing of the ferrous and transportation to the remanufacturer is excluded. The energy consumed in the remanufacturing process is also excluded because it is beyond the scope of this report.

Energy consumption not directly related to Sevierville or SSWI solid waste management programs, such as electricity usage at Sevierville and SSWI offices, is not included in this analysis.

The results of the energy consumption analysis are shown in Tables 5-4 and 5-5 at end of this section. The following discussion presents the methodology, data, and assumptions used to determine the results.

\subsection{Collection Vehicles}

Sevierville uses six vehicles to collect residential and commercial garbage. The type, year, and capacity of these vehicles is shown in Table 5-1. 
Table 5-1. Sevierville Garbage Collection Vehicles

\begin{tabular}{lcc}
\hline \multicolumn{1}{c}{ Type } & Year & Capacity (cubic yards) \\
\hline Residential and Small Commercial Accounts & & \\
Rear-loader & 1983 & 20 \\
Rear-loader & 1988 & 25 \\
Rear-loader & 1991 & 25 \\
Large Commercial (Dumpster) Accounts & & \\
Front-loader & 1987 & 38 \\
Front-loader & 1989 & 33 \\
Front-loader & 1992 & 38 \\
\hline
\end{tabular}

All of the Sanitation Department's vehicles run on diesel fuel. The quantity of fuel consumed by each vehicle in Sevierville's collection fleet was not readily available. However, Sevierville did provide the total dollar amount expended during FY 1993/94 of approximately $\$ 11,800$ and estimated the average cost of diesel fuel was approximately $\$ 0.65$ per gallon. Therefore, the total amount of diesel estimated to have been consumed for collecting garbage in Sevierville during FY $1993 / 94$ is 18,000 gallons. Based on the total quantity of garbage collected by Sevierville in FY $1993 / 94$ of 10,280 tons, the amount of diesel fuel consumed was equivalent to approximately 1.75 gallons per ton of garbage collected.

SSWI uses a 25 cubic yard Mack side loader to collect OCC from the commercial dumpsters. Information regarding fuel usage for this vehicle was not available. However, SSWI was able to provide the total amount of diesel consumed by all their equipment during FY 1993/94 which was approximately 14,200 gallons.

Major pieces of SSWI diesel equipment used at the recycling warehouse and Class I and IV landfills and the estimated percent of total diesel used are shown in Table 5-2. 
Table 5-2. SSWI Diesel Equipment

\begin{tabular}{lcc}
\hline \multicolumn{1}{c}{ Type } & Year & $\begin{array}{c}\text { Estimated Percent of } \\
\text { Diesel Usage }\end{array}$ \\
\hline Recycling Warehouse & & $15 \%$ \\
Forklift (make/model unknown) & 1992 & \\
Mack side-loading truck & 1993 & \\
Class I Landfill & & $63 \%$ \\
John Deer 762 B Pan Scraper & 1990 & \\
Revworks 3-55B Compactor & 1994 & $22 \%$ \\
Dresser TD15E Dozer & 1990 & \\
Class IV Demolition Landfill & & \\
Front-end loader (make/model unknown) & 1990 & \\
Tub grinder (make/model unknown) & 1992 & \\
Al Jon tire shredder & 1991 & \\
\hline
\end{tabular}

It was estimated that the OCC collection vehicle consumes approximately 13 percent of the diesel fuel used by all the SSWI equipment during FY 1993/94 or 1,800 gallons based on typical fuel consumption rates for similar vehicles and estimated hours of operation per year. This is equivalent to approximately 7.4 gallons of diesel per ton of commercial OCC collected based on 244 tons being recovered on a County-wide basis in FY 1993/94. The quantity of commercial OCC estimated to be collected from Sevierville and included in Analyzed MSW is 31 tons. Based on the calculated fuel consumption of 7.4 gallons of diesel per ton collected results in the estimated quantity of diesel being consumed to collect commercial OCC in Sevierville during FY 1993/94 of 230 gallons.

Table 5-3 presents a summary of the estimated energy consumed for collecting Analyzed MSW (garbage and commercial OCC) from Sevierville.

Table 5-3. Energy Consumed to Collect Analyzed MSW in Sevierville (FY 1993/94)

\begin{tabular}{lrr}
\hline & Garbage & Commercial OCC \\
\hline Analyzed MSW (tons) $^{[\mathrm{a}]}$ & 10,280 & 31 \\
Diesel Fuel Consumed (gallons) $^{[\mathrm{b}]}$ & 18,000 & 230 \\
Gallons Per Ton & 1.75 & 7.4 \\
\hline
\end{tabular}


Notes:

Analyzed MSW is defined and associated quantities presented in Table 4.

Diesel fuel consumed by collecting garbage was estimated based on data provided by Sevjerville on total expenditures for diesel fuel by the Sanitation Department and approximate cost per gallon of diesel fuel. Fuel consumed to collect OCC is estimated by first using limited SSWI data to estimate the gallons per ton used on a county-wide basis to collect OCC and then multiplying by the estimated quantity of OCC collected in Sevierville during FY 1993/94.

\subsection{Recycling Warehouse}

The two types of energy used at the recycling warehouse are electricity for the baler, lighting and auxiliaries and diesel fuel for the fork lift. SSWI records indicate a total of 49,319 kwh of electricity were used by the recycling warehouse and SSWI office during FY 1993/94. Of this amount, SSWI estimates that approximately 25 percent was for the office and 75 percent for the recycling warehouse. Therefore, the estimated quantity of electricity consumed during FY $1993 / 94$ at the recycling warehouse is estimated to be approximately $37,000 \mathrm{kwh}$.

The FY 1993/94 electricity consumed at the recycling warehouse for processing only OCC in Analyzed MSW as compared to all OCC processed at the recycling warehouse (31 tons versus 244 tons) was estimated to be approximately $4,700 \mathrm{kwh}$ assuming energy consumption is proportional to quantity of commercial OCC processed.

It was estimated that the forklift used approximately 2 percent of the diesel fuel used by all the SSWI equipment during FY 1993/94 or approximately 280 gallons based on typical fuel consumption rates for similar vehicles and estimated hours of operation per year. This is equivalent to approximately 1.1 gallons of diesel per ton of commercial OCC processed based on 244 tons being recovered on a County-wide basis in FY 1993/94. The quantity of commercial OCC estimated to be collected and processed from Sevierville and included in Analyzed MSW is 31 tons. Assuming a fuel consumption of 1.1 gallons of diesel per ton collected results in the estimated quantity of diesel being consumed to process commercial OCC in Sevierville during FY $1993 / 94$ of 35 gallons.

\subsection{Composting Facility}

Energy in the forms of electricity, diesel fuel and gasoline are consumed at the composting facility. Bedminster records indicate approximately $4,832 \mathrm{MWH}$ of electricity were consumed at the composting facility during FY 1993/94.

The FY 1993/94 electricity consumed at the composting facility for processing garbage in analyzed MSW as compared to all garbage processed at the composting facility $(10,120$ tons versus 50,240 tons if bypass is excluded) was estimated to be $970 \mathrm{MWH}$ (assuming electricity consumption is proportional to quality of garbage processed.)

Mobile equipment used at the composting facility during FY 1993/94 are shown in Table 5-4. With the exception of the pick-up truck, all mobile equipment at the composting facility use diesel fuel.

Because all diesel mobile equipment are fueled from an on-site diesel storage tank, information was not available on the quantity of fuel used by each individual piece of mobile equipment. 
Records from Bedminster show total diesel usage at the composting facility during FY 1993/94 was 16,297 gallons.

Table 5-4. Mobile Equipment Used at Composting Facility

\begin{tabular}{lllll}
\hline \multicolumn{1}{c}{ Model } & \multicolumn{1}{c}{ Description } & & Year & \multicolumn{1}{c}{ Fuel Type } \\
\hline CAT 936 & Front-end loader & 1992 &. & Diesel \\
CAT 926 & Front-end loader & 1992 & Diesel \\
MI 843 & Skid Steer Loader & 1992 & Diesel \\
Mack & Tractor & 1973, refurbished and rebuilt in & Diesel \\
& & 1992 & \\
Ford & Pick-Up Truck & 1992 & Gasoline \\
\hline
\end{tabular}

The FY 1993/94 diesel consumed at the composting facility for processing garbage in Analyzed MSW as compared to all garbage processed at the composting facility $(10,120$ tons versus 50,240 tons if bypass is excluded) was estimated to be approximately 3,280 gallons assuming diesel consumption is proportional to quantity of garbage processed.

The pick-up truck at the composting facility is used to collect parts either locally or sometimes as far as Knoxville. No data on fuel usage for this vehicle was available, so an estimate was made assuming it travels approximately 7,000 miles per year at approximately 18 miles per gallon. This results in an estimated gasoline usage of 390 gallons for FY 1993/94.

The FY 1993/94 gasoline consumed at the composting facility for processing garbage in Analyzed MSW as compared to all garbage processed at the composting facility $(10,120$ tons versus 50,240 tons if bypass is excluded) was estimated to be approximately 80 gallons (assuming gasoline consumption is proportional to quantity of garbage processed.)

\subsection{Class I Landfill}

Diesel fuel is the only type of energy consumed at the Class I landfill. Landfill equipment using this fuel include a pan scraper, compactor, and dozer.

As discussed previously, SSWI does not maintain records of the amount of fuel consumed by individual pieces of equipment. All diesel mobile equipment take fuel from an on-site diesel storage tank which is separate from the storage tank used by mobile equipment in the composting facility.

Based on estimates of the gallons per hour consumed and number of hours operated per year for each piece of equipment, an estimate of the gallons of diesel consumed by the pan scraper, compactor and dozer at the Class I landfill was developed. The total is estimated to be approximately 9,000 gallons for FY $1993 / 94$ or just over 60 percent of the total diesel fuel consumption by SSWI equipment. 
The FY 1993/94 diesel consumed at the Class I landfill for managing garbage in Analyzed MSW as compared to all garbage managed in the SSWI facilities (10,280 tons versus 51,043 tons) was estimated to be approximately 1,810 gallons (assuming gasoline consumption is proportional to quantity of garbage managed.)

\subsection{Hauling Recovered Materials to Market}

The commercial OCC collected by SSWI is baled and then transported by tractor-trailer to an enduser in Chattanooga, Tennessee at a distance of approximately 130 miles. Based on a detailed energy consumption analysis performed by CSI in Palm Beach County, it was assumed that fuel is consumed when hauling the OCC at a rate of $\$ 0.023$ per ton-mile based on a one-way mileage or $\$ 0.012$ per ton-mile based on a two-way mileage. This equates to using approximately 730 gallons of diesel fuel each year based on the estimated tonnage of commercial OCC in Analyzed MSW.

The FY 1993/94 diesel fuel consumed for hauling commercial OCC in Analyzed MSW as compared to all OCC hauled ( 31 tons versus 244 tons) was estimated to be approximately 90 gallons (assuming diesel consumption is proportional to quantity of commercial OCC processed.)

Ferrous recovered at the compost facility is hauled by tractor-trailer to an intermediate processor in Rockwood, Tennessee at a distance of approximately 80 miles. Again assuming the diesel fuel usage rate to be $\$ 0.023$ per ton-mile, this equates to using approximately 900 gallons of diesel to haul all ferrous recovered from Analyzed MSW at the composting facility to an intermediate processor. As discussed previously, energy consumed to perform the intermediate processing and subsequently transport the ferrous to a remanufacturer is not included in this analysis.

The FY 1993/94 gasoline consumed for hauling ferrous recovered from garbage processed at the compost facility which is part of Analyzed MSW as compared to all ferrous recovered from garbage at the composting facility (100 tons versus 496 tons) was estimated to be approximately 180 gallons (assuming diesel consumption is proportional to quantity of ferrous hauled.)

Bedminster does not have established markets for its compost product. Both local and distant outlets were utilized during FY 1993/94. Most of the distant outlets were testing sites where the compost was sent for evaluation. Shipping compost over such long distances is expected to significantly diminish in the future.

In order to prevent the temporary shipment of compost over long-distances from skewing the energy consumption data, it was assumed that all compost was distributed at an average distance of 10 one-way miles from the facility during FY 1993/94 via dump truck using diesel fuel. It was also assumed that the capacity of each dump truck was approximately 30 cubic yards with a fuel consumption rate of 6.5 miles per gallon and the compost has a density of approximately 800 pounds per cubic yard. Based on an estimated quantity of 15,300 tons of compost produced in FY 1993/94, this resulted in an estimated fuel usage of 3,900 gallons.

The FY 1993/94 diesel consumed for hauling compost derived from garbage in Analyzed MSW as compared to all garbage processed at the composting facility was estimated to be approximately 790 gallons (assuming diesel consumption is proportional to quantity of garbage processed, which 
is 10,120 tons in Analyzed MSW versus 50,240 tons total if bypass is excluded).

\subsection{Total Energy Consumption}

Based on the analysis discussed above, the total energy consumption during FY 1993/94 related to managing Analyzed MSW by type of energy was calculated. The results are shown in Table 5-5. Also, the total energy consumption in Btus was determined based on the following conversion factors which are consistent with factors used in the other case studies:

- $\quad$ Diesel Fuel: 146,390 Btu/gallon

- $\quad$ Gasoline: 127,650 Btu/gallon

- $\quad$ Electricity: $\quad 3,413 \mathrm{Btu} / \mathrm{kwh}$

Table 5-5. Total Energy Consumption for Managing Analyzed MSW (FY 1993/94)

\begin{tabular}{|c|c|c|c|c|}
\hline Activity & $\begin{array}{l}\text { Diesel Fuel } \\
\text { (gallons) }\end{array}$ & $\begin{array}{l}\text { Gasoline } \\
\text { (gallons) }\end{array}$ & $\begin{array}{c}\text { Electricity } \\
\text { (Mwh) }\end{array}$ & $\begin{array}{c}\text { Total Energy } \\
\text { (millions of } \\
\text { Btus) }\end{array}$ \\
\hline \multicolumn{5}{|l|}{ Collection Vehicles } \\
\hline Garbage & 18,010 & NA & NA & 2,640 \\
\hline Corrugated & 230 & NA & NA & 30 \\
\hline Subtotal & 18,240 & NA & NA & 2,670 \\
\hline \multicolumn{5}{|l|}{ Facilities } \\
\hline Recycling Warehouse & 35 & NA & 5 & 20 \\
\hline Composting Facility & 3,280 & 80 & 970 & 3,800 \\
\hline Class I Landfill & 1,810 & NA & NA & 260 \\
\hline Subtotal & 5,125 & 80 & 975 & 4,080 \\
\hline \multicolumn{5}{|l|}{ Haul to Markets ${ }^{[b]}$} \\
\hline Compost & 790 & NA & NA & 120 \\
\hline Corrugated & 90 & NA & NA & 10 \\
\hline Ferrous & 180 & NA & NA & 30 \\
\hline Subtotal & 1,060 & NA & NA & 160 \\
\hline TOTAL & 24,425 & 80 & 975 & 6,910 \\
\hline
\end{tabular}


Notes:

(a) Based on assumptions used in other case studies, energy content of diesel fuel assumed to be 146,390

Btus/gallon and energy content of gasoline assumed to be 127,650 Btus/gallon. Electricity usage converted to

Btus assuming $3413 \mathrm{Btus} / \mathrm{kWh}$. Diesel fuel usage for collection vehicles taken from Table 17.

(b) Includes energy consumed to haul materials to first destination after leaving SSWI site. For compost and OCC, the first destination is the end-user/remanufacturer. This destination for ferrous is an intermediate processor. Data on energy consumption at the intermediate processing facility and energy consumed while hauling the ferrous to a remanufacturer were not available.

The estimated total energy consumed during FY $1993 / 94$ for managing Analyzed MSW is 6,910 million Btus or 0.7 million Btus per ton managed. The energy consumption in Btus can be broken down by type of activity as follows:

- Collection:

- $\quad$ Facilities:

- Hauling:
39 percent

59 percent

2 percent

\subsection{Equivalent Energy Consumption}

The energy consumption for managing each category of Analyzed Waste is shown in Table 5-6 on the basis of equivalent gallons of diesel consumed. These amounts were calculated by converting the total Btu energy consumption figures in Table 5-5 into equivalent gallons of diesel assuming diesel has an energy content of 146,390 Btus per gallon.

The estimated equivalent gallons of diesel used to manage the garbage in Analyzed MSW is 4.55. For managing the commercial OCC in Analyzed MSW, total energy consumption was estimated to be 13.99 equivalent gallons of diesel per ton.

Using the above energy consumption estimates for each Analyzed MSW category, the weighted average equivalent gallons of diesel per ton for managing all Analyzed MSW was determined to be 4.58 as shown in Table 5-6. 
Table 5-6. Equivalent Per Gallon Energy Consumption for Managing Analyzed MSW (FY 1993/94 Equivalent Diesel Gallons Per Ton)

\begin{tabular}{|c|c|c|c|}
\hline \multirow[b]{2}{*}{ Activity } & \multicolumn{3}{|c|}{ Equivalent Diesel Gallons Per Ton } \\
\hline & Garbage & $\begin{array}{l}\text { Commercial } \\
\text { Corrugated }\end{array}$ & $\begin{array}{c}\text { Total Analyzed } \\
\text { MSW }\end{array}$ \\
\hline \multicolumn{4}{|l|}{ Collection Vehicles } \\
\hline Garbage & 1.75 & NA & 1.75 \\
\hline Corrugated & NA & 7.38 & 0.02 \\
\hline Subtotal & 1.75 & 7.38 & 1.77 \\
\hline \multicolumn{4}{|l|}{ Facilities } \\
\hline Recycling Warehouse & NA & 4.41 & 0.01 \\
\hline Composting Facility & 2.53 & NA & 2.52 \\
\hline Class I Landfill & 0.17 & NA & 0.17 \\
\hline Subtotal & 2.70 & 4.41 & 2.70 \\
\hline \multicolumn{4}{|l|}{ Haul to Markets [b] } \\
\hline Compost & 0.08 & NA & 0.08 \\
\hline Corrugated & NA & 2.20 & 0.01 \\
\hline Ferrous & 0.02 & NA & 0.02 \\
\hline Subtotal & 0.10 & 2.20 & 0.11 \\
\hline TOTAL & 4.55 & 13.99 & 4.58 \\
\hline
\end{tabular}

Notes:

Is) Based on assumptions used in other case studies, energy content of diesel fuel assumed to be 146,390 Btus/gallon. Total Btus taken from Table 20. Quantity of garbage in Analyzed MSW is 10,280 tons. Quantity of commercial OCC in Analyzed MSW is 31 tons.

(b) Includes energy consumed to haul materials to first destination after leaving SSWI site. For compost and OCC, the first destination is the end-user/remanufacturer. This destination for ferrous is an intermediate processor. Data on energy consumption at the intermediate processing facility and energy consumed while hauling the ferrous to a remanufacturer were not available. 


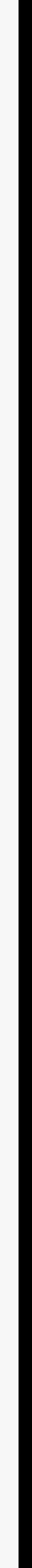




\section{Environmental Regulations and Permitting Requirements}

The costs of compliance with the environmental and safety regulations and permit requirements discussed in this Section are reflected in the costs reported in this Study.

\subsection{Overview of Relevant Federal Environmental Legislation and Regulations}

The potential environmental impacts of solid waste management facilities have led to the development of an extensive network of federal and state regulations. Embodied in many federal environmental laws is an implicit federal-state partnership whereby the federal government sets the agenda and standards for pollution abatement while the states carry out the day-to-day activities of implementation and enforcement.

The Clean Air Act, most recently amended in 1990, established programs for protecting public health and the environment from exposure to gaseous emissions, including toxic air pollutants. ${ }^{1}$ The Clean Water Act, most recently amended in 1987, is the principal federal law protecting the nation's waterways from pollution. ${ }^{2}$ The Safe Drinking Water Act, most recently amended in 1988, established programs for protecting public drinking water systems from harmful contaminants. ${ }^{3}$ The Solid Waste Disposal Act and Resource Conservation and Recovery Act (RCRA) of 1976, most recently amended in 1992 and currently undergoing Congressional review for reauthorization, is the main piece of federal legisiation addressing landfill disposal regulation. ${ }^{4}$

In that the County's IMSWMS does not include solid waste combustion, the Clean Air Act did not currently apply to the facilities comprising the IMSWMS. However, proposed changes to the Clean Air Act may apply to the IMSWMS. Specifically, the Clean Air Act would require the installation of an active gas system at MSW landfills that (1) were operational on November 8, 1987 , (2) have a capacity of 110,000 tons, and (3) discharge 167 tons per year of non-methane organic compounds (NMOC).

Pursuant to the Clean Water Act, a solid waste management facility cannot cause a discharge of pollutants that is in violation of the requirements of the National Pollutant Discharge Elimination System (NPDES) into United States waters. The states are responsible for establishing water quality standards and are authorized to issue discharge permits. In Tennessee, the NPDES permit is issued to the publicly owned treatment works (POTW), which will receive leachate and stormwater runoff from the IMSWMS. The NPDES permit requires the source to attain technology-based effluent limits, "best practicable control technology" (BPT), and "best available technology" (BAT). The initial BPT limitations focus on regulating discharges of conventional pollutants such as bacteria and oxygen-consuming materials. The BAT limitations emphasize controlling toxic pollutants such as heavy metals, pesticides, and other organic chemicals. Table 6-1 provides a listing of the pollutants typically regulated under the NPDES.

1 The Clean Air Act and Major Amendments are codified as 42 U.S.C 7401-7671, 1990.

2 The Clean Air Act and Major Amendments are codified as 33 U.S.C. 1251-1387, 1987.

3 The Safe Drinking Water Act and Amendments are codified as 42 U.S.C. 300f-300j-11, 1987.

4 The Solid Waste Disposal/Resource Conservation and Recovery Act and Major Amendments are codified as 42 U.S.C. 6901-6991k, 1992. 
A separate permit is required to dispose of dredge or fill material into waterways, including wetlands. The U.S. Army Corps of Engineers administers this permit program. Other regulations promulgated under the Clean Water Act include guidelines for using and disposing of sewage sludge. The guidelines for sewage sludge are addressed later in this report in the subsection on the composting facility.

Table 6-1. Pollutants Regulated by the NPDES Permit Program

\begin{tabular}{|c|c|}
\hline $\begin{array}{l}\text { Oxygen Demand: } \\
\text { Biochemical Oxygen Demand } \\
\text { - } \\
\text { Chemical Oxygen Demand } \\
\text { - Total Oxygen Demand } \\
\text { Total Organic Carbon } \\
\text { Other }\end{array}$ & $\begin{array}{ll}\text { Metals: } & \\
& \text { Aluminum } \\
- & \text { Cobalt } \\
\text { - } & \text { Iron } \\
& \text { Vanadium }\end{array}$ \\
\hline $\begin{array}{ll}\text { Solids: } & \\
\text { - } & \text { Total Suspended Solids (Residues) } \\
\text { - } & \text { Total Dissolved Solids (Residues) } \\
\text { Other }\end{array}$ & $\begin{array}{l}\text { Metals (All Forms): } \\
\text { - } \quad \text { Other metals not specifically listed } \\
\text { - } \\
\text { Under Group } 1\end{array}$ \\
\hline $\begin{array}{l}\text { Nutrients: } \\
\text { - } \quad \text { Inorganic Phosphorus Compounds } \\
\text { - } \quad \text { Inorganic Nitrogen Compounds } \\
\text { Other }\end{array}$ & $\begin{array}{l}\text { Inorganic: } \\
-\quad \text { Cyanide } \\
\cdot \quad \text { Total Residual Chlorine }\end{array}$ \\
\hline $\begin{array}{l}\text { Detergents and Oils: } \\
\text { MBAS } \\
\text { NTA } \\
\text { - } \quad \text { Oil and Grease } \\
\text { Other Detergents or Algicides }\end{array}$ & $\begin{array}{ll}\text { Minerals: } \\
\text { - } & \text { Calcium } \\
\text { - } & \text { Chloride } \\
\text { - } & \text { Fluoride } \\
\text { - } & \text { Magnesium } \\
\text { - } & \text { Sodium } \\
\text { - } & \text { Potassium } \\
\text { - } & \text { Sulfur } \\
\text { - } & \text { Sulfate } \\
\text { - } & \text { Total Alkalinity } \\
\text { - } & \text { Total Hardness } \\
\text { - } & \text { Other Minerals }\end{array}$ \\
\hline
\end{tabular}

Pursuant to the Safe Drinking Water Act, a facility or practice cannot contaminate an underground drinking water source beyond the solid waste management boundary or beyond an alternate boundary. Table 6-2 provides the maximum contaminant levels as promulgated under this Act. The primary enforcement responsibility lies with the states, provided they adopt regulations as stringent as the federal requirements, develop adequate procedures for enforcement, maintain records, and create plans providing emergency water supplies.

Pursuant to RCRA, criteria were established to determine which solid waste disposal facilities and 
practices pose a reasonable probability of adverse effects on public health or the environment. ${ }^{5}$ The objective of these criteria is to mitigate adverse effects through the protection of floodplains, endangered species, surface water, and groundwater. These criteria also provide guidelines for sludge utilization and disposal under the Clean Water Act.

Subtitle D of RCRA primarily addresses non-hazardous waste, whereas Subtitle C of RCRA addresses hazardous waste disposal. In October 1991, the EPA promulgated revised Subtitle D regulations applicable to municipal solid waste landfills, with an effective date of October 1993. In general, the new regulations require liners, leachate collection, groundwater monitoring, and corrective action at municipal landfills. ${ }^{6}$

\subsection{Overview of State and Local Environmental Regulations}

Municipal solid waste management is regulated in accordance with Tennessee's Solid Waste Management Act of 1991 (T.C.A. 68-211-813(c) and 68-211-815). The Act was also amended in 1992 (Chapters 693, 759).d The law is administered by the Tennessee Department of Health and Conservation (TDEC) Solid Waste Management Division. The Act designated the formation of municipal solid waste "regions" which in the case of this Study includes the County and its four municipalities. Each region was to have submitted a plan to the state's Solid Waste Assistance Program for review. The Sevier Solid Waste Regional Board submitted its plan in July 1994. The rules and regulations for the management of MSW are provided in Chapter 1200, Solid Waste Processing and Disposal.

The state has adopted solid waste storage, processing and disposal regulations and performance standards for landfills consistent with the federal Subtitle D regulations. Requirements for leachate and gas mitigation and control are effective in October, 1996. The regulations are divided into several parts. Of principal note to the IMSWMS are: Rule 1200-1-7-.02, which establishes procedures and terms for permitting solid waste facilities; and, Rule 1200-1-7-.04, which details specific facility standards for operating Class I, II, III, and IV disposal facilities. Rule 1200-1-7.09 establishes a waste reduction goal of 25 percent by December 31, 1995. In FY 1993/94, Sevier Solid Waste reported a 70 percent recycling/reduction rate.

There are also specific restrictions on the disposal of special wastes (including sludges, bulky wastes, pesticides, and industrial/hazardous wastes), tires, medical wastes, and dead animals. To

s 40 CFR, EPA, Part 257--Criteria For Classification of Solid Waste Disposal Facilities and Practices.

6 On October 1, 1993, the Federal criteria for MSW landfills under subtitle D of RCRA were amended to extend the date of compliance for small landfills to April 9, 1994, and by delaying the effective date of subpart $G$, Financial Assurance, to April 9, 1995, for all MSW landfills. In addition, the MSW landfill criteria were amended by removing the exemption from the groundwater monitoring requirements and by delaying the date for compliance with all requirements of the MSW landfill criteria for two years for owners and operators of MSW landfill units in arid and remote areas that meet the qualifications of the small landfill exception in the MSW landfill criteria. (Federal Register, "Solid Waste Disposal Facility Criteria; Delay of Compliance and Effective Dates," Vol. 58, No. 189, pages 51536-51548, 1993.) 
Table 6-2. Maximum Contaminant Levels ${ }^{[a]}$ (MCL) Promulgated Under the Safe Drinking Water Act

\begin{tabular}{|c|c|}
\hline Chemical & MCL (mg/l) \\
\hline Arsenic & 0.05 \\
\hline Barium & 1.0 \\
\hline Benzene & 0.005 \\
\hline Cadmium & 0.01 \\
\hline Carbon Tetrachloride & 0.005 \\
\hline Chromium (Hexavalent) & 0.05 \\
\hline 2,4-Dichlorophenoxy Acetic Acid & 0.1 \\
\hline 1,4-Dichlorobenzene & 0.075 \\
\hline 1,2-Dichloroethabe & 0.005 \\
\hline 1,1-Cichloroethylene & 0.007 \\
\hline Endrin & 0.0002 \\
\hline Fluoride & 4.0 \\
\hline Lindane & 0.004 \\
\hline Lead & 0.05 \\
\hline Mercury & 0.002 \\
\hline Methoxychlor & 0.1 \\
\hline Nitrate & 10.0 \\
\hline Selenium & 0.01 \\
\hline Silver & 0.05 \\
\hline Toxaphene & 0.005 \\
\hline 1,1,1-Trichloroethane & 0.2 \\
\hline Trichlorethylene & 0.005 \\
\hline 2,4,5-Trichlorophenoxy Acetic Acid & 0.01 \\
\hline Vinyl Chloride & 0.002 \\
\hline
\end{tabular}

Note:

10) 40 CFR EPA Part 257 - Criteria for Classification of Solid Waste Disposal Facilities and Practices. 
address issues involving these types of waste materials, the County implemented a tire shredding and stockpiling area, a wood waste grinding operation, wood pallet reused program and ferrous recovery program at the Class IV demolition landfill, and a MSW/sewage sludge co-composting plant. The co-composting facility is operated by Bedminster.

\subsubsection{Permit Requirements for Each IMSWMS Facility}

This section briefly summarizes the permit conditions for each of the facilities included in SSWI's IMSWMS. IMSWMS components include: 1) a Class I sanitary landfill; 2) a Class IV landfill for demolition waste (and a tire storage facility); 3) a co-composting facility for sewage sludge and MSW; 4) a recycling warehouse for processing and storage of OCC and 5) drop-off centers for collection of plastic, aluminum, newspaper, and motor oil.

\subsubsection{Composting Facility}

In September of 1992, Bedminster began operating a composting facility under a five-year contract with SSWI. The facility was designed to process up to 150 tons of MSW and 75 tons of sewage sludge per day.

Composting facility regulations and end product standards are currently being developed for the State of Tennessee. Thus, no composting regulations were in place for the State of Tennessee at the time of the signing of the contract between Bedminster and SSWI. However, Article IV of the contract requires the facility to follow Florida MSW Compost production criteria (Rule 17-709 F.A.C.) as "acceptance criteria". These Florida rules (which are currently under revision) set forth certain design and operational criteria for facilities that compost MSW.

In lieu of a formal permit, the TDEC sent the facility a set of minimum standards under which the facility was granted "permit by rule" status. The TDEC enforces these standards by arranging monthly inspections of the facility. One recurring problem has been with seepage underneath one of the biofilters. Excess percolate from the biofilters was directed to a sediment pond, but this practice was discontinued at the request of the TDEC. Excess leachate continued to be observed from the biofilters as recently as early November 1994. Bedminster reports that a wet well will be installed to recirculate percolate through the biofilters.

Since the facility processes sludge in a addition to MSW, the facility is bound to conform to standards for the final use or disposal of sewage sludge, per section 503 of the Clean Water Act. According to the rule, the finished product is considered "exceptional quality" and allowed unlimited distribution if certain criteria are met. These criteria can be grouped as follows:

- $\quad$ Pathogen Reduction Requirements

- Vector Attraction Reduction Requirements

- $\quad$ Surface Disposal Concentration Limits

The pathogen and vector reduction requirements are met by maintaining certain temperatures in the composting mass for a specified period of time. The surface disposal concentration limits are dry weight concentrations for certain potentially harmful metals which are know to appear in sewage sludge. The Bedminster composting facility's operation plan and end product lab results indicate that Bedminster's product meets the criteria for exceptional quality and unlimited distribution. 


\subsubsection{1a Odor Complaints}

Bedminster encourages nearby residences to call the composting facility when they have odor concerns. To date, the majority of odor complaints come from the three or four neighboring residences located within a quarter mile radius of the facility. The closest neighbor is located across the main access road northwest of the facility. The wind direction goes from north to south during the day but shifts to south to north at sunset. As a result, most of the calls to the facility regarding odor concerns are received in the evening.

Approximately 15 to 20 calls regarding odor were received by Bedminster during the period from September 1992 to early January 1993. This high volume of odor complaints was attributed to the facility operating before construction was complete. A significant reduction in telephone calls regarding odors was noted after the completion of the enclosure of the curing building and the biofilter system.

Since January 1993, the frequency of telephone calls regarding odor has followed a seasonal pattern. During the off-peak MSW delivery months, the facility receives approximately one telephone call regarding odor every four to six weeks. Bedminster claims that odor complaints received during these off-peak months are usually attributed to operator error or mechanical malfunction (e.g., tip floor door left open, or failure of a biolfilter fan). Bedminster usually has the capability to thwart potential odor problems by using its centralized computer control system. Mechanical malfunctions that occur after business hours are noted by the facility's central computer system, which automatically dials the telephone number of an on-call plant operator.

Telephone calls regarding odor are usually more frequent during the summer months associated with the heavy tourist season. The frequency of telephone calls is estimated to be four to five per month. The occurrence of odor problems during these months is associated with the biofilter system not being able to effectively capture odors when the plant is running 25 to 30 percent over capacity.

\subsubsection{1b Regulatory Authority Concerning Odor at Tennessee Composting Facilities}

The Tennessee Solid Waste Disposal Act states that it is unlawful to construct or operate a solid waste facility that creates a public nuisance. However, the word "nuisance" is not defined in the law, and the solid waste regulations that resulted from the Tennessee Solid Waste Disposal Act contain no mention of odor. As a result, the TDEC cannot cite "odor violations" during monthly inspections of solid waste facilities. Any enforcement action based on the grounds of violating the "nuisance" provision of the Tennessee Solid Waste Disposal Act would be passed on to the state's attorneys, and be reviewed by the Attorney General prior to the issuance of an enforcement order. The next step would be the issuance of penalties to the odor-generating solid waste facility. According to the TDEC, such a course of events has never occurred at any of the state's solid waste facilities.

The TDEC will gain more direct control over citing violations and issuing penalties to composting facilities when the composting regulations currently being drafted become law. According to the TDEC, the current draft of the regulations contains a provision on odor, which would enable the facility inspectors to cite odor violations during their visits. The existence of composting regulations will facilitate the issuance of penalties for repeated, uncorrected violations. 


\subsubsection{Processing Facilities}

Key processing facilities operated by SSWI include a recycling warehouse for storage and baling of OCC, and a wood chipping operation, designed to produce mulch-products for residential use. Like the composting facility, processing facilities are regulated under the "permit-by-rule" program administered by the TDEC Solid Waste Management Division. A review of TDEC files indicated that the wood chipping operation has been notified of storage and drainage problems.

\subsubsection{Landfilis}

\subsubsection{3a Class I Landfill}

SSWI operates a Class I landfill for all MSW that is not separated, recycled, or reprocessed as well as MSW that bypasses the composting facility. The permit for SSWI's currently operating Class I landfill, was issued in June, 1993 by the TDEC. Prior to commencement of operations at the present landfill, SSWI used an extension of a four-phase landfill originally owned and operated by the City of Gatlinburg. The oldest phases of that landfill date to the mid-1970s. Closed portions of the landfill were cited beginning in 1991 for violations of closure and postclosure standards for monitoring erosion control and leachate control. Due to on-going noncompliance by SSWI, fines in excess of $\$ 20,000$ were assessed to SSWI in July 1993. Continued problems related to the original notice of violation were identified during an inspection of inactive landfill areas in mid-1994. Corrective actions appear to have been taken, with no apparent enforcement taken by TDEC.

In accordance with TDEC regulations, the new Class I landfill incorporates key elements of Rule 1200-1-7-.04, including: controls for run-on/runoff; management of special wastes; composite liner capable of controlling leachate migration; leachate collection and removal systems that convey leachate to a collection tank; and solid waste handling and cover standards. The facility must be operated to meet the minimum concentration values for groundwater protection. Inspection of the Class I landfill (phase A) by the TDEC found that garbage was placed against sideslope liners rather than placing a protection layer of soil between the first lift of waste and the landfill liner. Inspection reports also indicate additional litter control was necessary, the working face of the landfill was too large and leachate has been observed in surface water control features.

\subsubsection{3b Class IV Landfill}

A five-foot thick geologic buffer, with a maximum permeability of $1 \times 10^{-5} \mathrm{~cm} / \mathrm{sec}$ (or an equivalent or superior buffer), between the base of the landfilled material and the high water table is required at a Class IV landfill. Leachate collection and gas migration controls are not required at a Class IV disposal facility. Cover is to be placed on Class IV waste at least every 30 days. Class IV disposal facilities are typically exempt from having to implement a groundwater monitoring system. Waste tire handling and disposal practices in the County meet state guidelines with a permitted tire storage area at the demolition landfill. Present storage capacity is 30,000 tires. Under the State of Tennessee Mobile Tire Shredding Plan, in 1993 the County shredded over 27,000 tires. Shredded tires are presently being stockpiled pending development of a recycling market. There are no known illegal tire dumps in the County. Review of TDEC site inspection reports indicated that violations related to the landfilling of unacceptable materials, including compost and MSW, along with demolition waste have been noted and corrected. 


\subsubsection{3c Special Wastes}

Wastes that are collected within the County, but deemed unacceptable for disposal at either the Class I or IV landfills include lead acid batteries and waste oil. Presently, waste oil is collected at several locations and recycled. Lead acid batteries are collected and recycled by local automotive service centers in the region. In 1993, the TDEC developed requirements for temporary locations within counties for the collection, sorting and packaging of HHW. In keeping with the states "1993 Policy Guide on County Responsibilities for the Tennessee HHW Collection Program," the County selected the Class IV demolition landfill as a temporary HHW Collection site. Implementation of the HHW program is expected to occur in 1995.

\subsection{Overview of Occupational Health and Safety Regulations}

\subsubsection{Federal Regulations}

The Occupational Safety and Health Act of $1970^{7}$ imposes two basic duties on private employers. State and local governments in their role as employers are not required to comply with these duties, which are:

1. To comply with occupational safety and health standards developed by the Occupational Safety and Health Administration (OSHA) pursuant to the Occupational Safety and Health Act; and

2. To comply with the General Duty Clause, Section S(a)(1), which requires that employers protect their employees from recognized hazards not regulated by an OSHA standard.

Pursuant to the Occupational Safety and Health Act, OSHA, created within the Department of Labor, is responsible for promulgating legally enforceable standards. These OSHA standards require conditions, or the adoption or use of one or more practices, means, methods, or processes, reasonably necessary and appropriate to protect workers on the job. These standards include the General Industry Standards, 29 CFR Part 1910, which apply to all workplaces unless more specific OSHA standards apply. The General Industry Standards are applicable to solid waste processing facilities. An outline of the General Industry Standards appears in Table 6-3. Refer to 29 CFR 1910 for the complete text of the standard.

Periodic inspections, either routine or in response to complaints, are conducted by OSHA to ensure that specific applicable standards are being met and that the workplace is generally free from recognized hazards likely to cause serious injury or death. When OSHA compliance officers discover areas of non-compliance resulting in hazards, employers may be issued citations, and penalties and abatement periods may be proposed.

\subsubsection{State and Local Safety Requirements}

OSHA provisions, as previously mentioned, do not apply to state and local governments in their role as employers. The Act does provide that any state desiring to gain OSHA approval for its private sector occupational safety and health program must provide a program that covers its state and local government workers and that is at least as effective as its program for private

\footnotetext{
7 Occupational Safety and Health Act of 1970, 5 USC 5108, 1970, most recently amended October 1992.
} 
employees. State plans may also cover only public sector employees. The State of Tennessee has an OSHA-approved state plan. The plan, with a few minor exceptions, is consistent with Federal OSHA regulation, and is administered through the Tennessee Department of Labor.

Private employers are required to comply with the General Industry Standards included in the Tennessee Occupational Safety and Health Plan. Thus, the SSWI owned but privately operated compost facility must comply.

Table 6-3. OSHA General Industry Standards - 29 CFR 1910

\begin{tabular}{ll}
\hline \multicolumn{1}{c}{ General Industry Standards } & Subpart \\
\hline General Requirements & Subpart A \\
Adoption and Extension of Federal Standards & Subpart B \\
General Safety and Health Provisions & Subpart C \\
Walking-Working Surfaces & Subpart D \\
Means of Egress & Subpart E \\
Powered Platforms, Manlifts, and Vehicle-Mounted Work Platforms & Subpart F \\
Occupational Health and Environmental Control & Subpart G \\
Hazardous Materials & Subpart H \\
Personal Protective Equipment & Subpart I \\
General Environmental Controls & Subpart J \\
Medical and First Aid & Subpart K \\
Fire Protection & Subpart L \\
Compressed Gas and Compressed Air Equipment & Subpart M \\
Materials Handling and Storage & Subpart N \\
Machinery and Machine Guarding & Subpart O \\
Hand and Portable Powered Tools and Other Hand-Held Equipment & Subpart P \\
Welding, Cutting, and Brazing & Subpart Q \\
Special Industries & Subpart R \\
Electrical & Subpart S \\
Commercial Diving Operations & Subpart T \\
\hline
\end{tabular}





\subsection{References}

Association County Commissioners of Georgia, "Waste + Composting = Topsoil", Georgia County Government, October 1993.

Bedminster, "Compost Quality Documentation."

Bedminster, "OrganagrO@ Compost Information."

Bedminster, "Fact Sheet - Sevier Solid Waste Composting Facility."

Bedminster, "Sevier, Tennessee Facility Waste/Residue/Electricity Comparison", Fax from T.J. Williams to Alan Cohen, October 14, 1994.

Bedminster, "Bedminster Bioconversion Corporation Operating Cost for the Fiscal Year Ending June 30, 1994" and "Bedminster Bioconversion Corporation Weight Summary for the Fiscal Year Ending June 30, 1994", Fax from T.J. Williams to Dan Cearley, November 30, 1994.

Bedminster, Fax from T. J. Williams to Dan Cearley containing list of composting facility equipment, November 23, 1994.

Bedminster, Summary of compost shipments for January through June, 1994.

Bedminster, "A Citizen's Guide to the Sevier County Composting Plant".

Bedminster, "Haulers."

Bedminster, "1993 Tennessee Compost Shipments".

Bedminster, "Solid Waste Composting Council, Compost Facility Operating Guide, Operating Facility Site Visit Pre-Visit, Information Request", Fax from Ken Aiani to Steve Jones, June 9, 1993.

Bureau of Economic Analysis, Local Planning Assistance, Department of Economic and Community Development, "Population Projection, 1990-2000 for Sevier County".

Case Study: Scottsdale, Arizona Integrated Municipal Solid Waste Management System, prepared for the Solid Waste Association of North America, prepared by CSI Resource Systems, Inc., August 1994.

Case Study: Springfield, Massachusetts Integrated Municipal Solid Waste Management System, prepared for the Solid Waste Association of North America, prepared by CSI Resource Systems, Inc., July 1994.

Case Study: Palm Beach County, Florida Integrated Municipal Solid Waste Management System, prepared for the Solid Waste Association of North America, prepared by CSI Resource Systems, Inc., June 1994., 
Case Study: Seattle, Washington Integrated Municipal Solid Waste Management System, prepared for the Solid Waste Association of North America, prepared by CSI Resource Systems, Inc., January 1994.

Charter of Sevier Solid Waste, Inc., December 7, 1988.

Cohen, Alan, Notes containing information gathered from SSWI and the City of Sevierville.

East Tennessee Development District, "Housing Units, Households and Population Per Household", March 1991.

East Tennessee Development District, "Tennessee Community Data Sevierville, Tennessee."

East Tennessee Development District, "Sevier County Economic Statistics, Summer, 1994."

The Fact Book of the Great Smokies, Edited by Delman D. Dennis, Nandel Publishing Company, Copyright 1994.

Goldstein, Nora, "Cocomposting in Tennessee," BioCycle, November 1993.

Hancock, Chandler, Letter from Hancock Horticultural Services to Ms. Rebecca Roe of Bedminster of Tennessee, Inc., January 27, 1994.

Hickman and Company, P.C., "Sevier Solid Waste, Inc. Financial Statements," June 30, 1993 and 1992.

Hickman and Company, P.C., "Sevier Solid Waste, Inc. Financial Statements," June 30, 1994 and 1993.

Hickman and Company, P.C., Miscellaneous trial balance worksheets for Sevier Solid Waste, Inc. Financial Statement for Fiscal Year 1993/94.

Hiscock, Ed, "Meeting the MSW Composting Challenge," Solid Waste Technologies, Industry Sourcebook 1994.

Local Planning Assistance Office, Sevier County Solid Waste Plan, Department of Economic and Community Development, Knoxville, Tennessee, October 1990.

Sevier County, "Blue Book," A Directory of Sevier County Organizations \& Services, 1994-95.

City of Sevierville, Solid waste ordinances.

City of Sevierville, "Annual Budget," Fiscal Year 1994-1995.

City of Sevierville, "Trucks, City of Sevierville" and "Gas Billings Street and Sanitation Department."

City of Sevierville, "Sevierville Citizen", October 1994. 
SSWI, "Yearly Waste Report - January 1, 1993 through December 31, 1993," Computer Printout, January 3, 1994.

"Solid Waste Facilities Construction and Operating Agreement between Sevier Solid Waste Inc. and Bedminster Bioconversion Corporation," September 19, 1991.

SSWI, "Yearly Waste Report - July 1, 1993 through June 30, 1994," Computer Printout, June 30, 1994.

SSWI, "Sevier County Solid Waste Regional Plan," Sevier Solid Waste Regional Board, July 1, 1994.

SSWI, "Summary of Assets - Accumulated Depreciation," June 30, 1994.

SSWI, "Amortization Expenses, FY 93-94."

SSWI, Equipment depreciation schedules.

[Source Unknown] Appendix C, Illustrative Calculation of Estimated Total Current Cost of MSWLF Closure and Postclosure Care and Current-Period Expenses and Liabilities Amounts.

[Source Unknown], Sevier Solid Waste Composting Facility flow diagram.

Tennessee Department of Conservation, files on SSWI facilities.

U. S. Department of Commerce, Bureau of the Census, 1990 Census of Populaton and Housing. Waters, Larry, "Waste Not, Want Not", American City \& County, June 1993. 



\section{Appendix A \\ Glossary of Terms}

ALLOCATED COST (\$/year):

ANALYZED MSW:

AVERAGE COST

AVERAGE PROGRAM INCREMENTAL COST (SAVINGS) (\$/ton):

BULKY WASTE:

COMMERCIAL MSW:

GARBAGE:
That portion of the Total Cost that is expended or apportioned to a specific activity such as the management of garbage, trash, recyclables, yard waste, or household hazardous waste.

Portion of the MSW stream for which the cost of collecting, transferring, hauling, processing, combusting, marketing, and/or disposing of such waste is known or can be reasonably estimated.

(\$/ton):Total or Allocated Cost divided by the tons of MSW, garbage, trash, recyclables, or yard waste, as appropriate.

The Program Incremental Cost divided by the number of tons of materials diverted from the landfill by the program.

Oversized items, including white goods and furniture, that have been separated from the MSW stream for separate collection.

Municipal solid waste that is generated by sources other than households, including businesses (e.g., offices, restaurants, retail stores, and industry); institutions (e.g., schools and government establishments); and public areas (e.g., train stations, airports, and litter from roadside).

Garbage is all MSW exclusive of sourceseparated trash, recyclables, yard waste, household hazardous waste, and bulky waste. 
HAZARDOUS WASTE:

HOUSEHOLD HAZARDOUS WASTES (HHW):

INTEGRATED SOLID WASTE MANAGEMENT:

MARGINAL COST (SAVINGS) (\$/ton):

MARGINAL COST (SAVINGS) OF SUBSTITUTION (\$/ton):

MATERIALS RECOVERY:

MUNICIPAL SOLID WASTE (MSW):
Waste which because of its quantity, concentration, or physical, chemical, or infectious characteristics, may pose a substantial present or potential hazard to human health or the environment when improperly treated, stored, transported, disposed of, or otherwise managed and is defined as such in accordance with federal and State laws. Does not include Household Hazardous Waste.

Materials that are separated from Residential MSW as household hazardous wastes for separate collection and treatment. Such materials may include paints and solvents, pesticides, herbicides, and propane tanks.

A practice of using several (i.e., two or more) alternative waste management techniques to treat, process, and/or dispose of the Municipal Solid Waste stream. Alternative waste management techniques include source reduction, recycling, composting, combusting, and landfilling.

The cost (savings) of managing an additional ton of MSW, garbage, trash, recyclables, or yard waste.

The net cost (savings) of managing an additional ton of recyclables or yard waste less the savings (cost) of managing one less ton of garbage.

A term describing the extraction and utilization of materials from a waste stream.

Non-hazardous solid wastes generated by households, commercial and business establishments, institutions, and light industry; it excludes industrial process wastes, agricultural wastes, mining wastes, construction and demolition debris, offal, 
sludges, and ashes, except ashes derived from the combustion of MSW. In practice, specific definitions vary across jurisdictions.

PROGRAM INCREMENTAL COST (SAVINGS) (\$/year):

RECOVERED MATERIALS:

RECYCLABLE MATERIALS OR RECYCLABLES:

RECYCLE:

RESIDENTIAL MSW:

RESIDUE:

RESOURCE RECOVERY:

SECONDARY MATERIAL:
The difference between the cost of managing MSW with or without a particular program (e.g., curbside collection, processing, and marketing of recyclables.)

Recyclable materials that are recovered from MSW and may also include some contamination.

Materials that still have useful physical or chemical properties after serving their usefulness for a given individual or firm and can, therefore, be reused or recycled for the same or other purposes.

To convert discarded materials into useful products through reuse and remanufacturing.

Municipal solid waste that is generated by households.

That portion of processed MSW that is ultimately disposed of in a landfill.

A term describing the extraction and utilization of energy or materials from a waste stream.

A material that is used in place of a primary or raw material in manufacturing a product; often handled by dealers and brokers in "secondary markets." 
The delivery of MSW or other wastes to an integrated municipal solid waste management system by a private firm or individual that is not under contract to a municipality, authority, utility, or other public entity responsible for municipal solid waste management to make such deliveries.

TOTAL NET COST OR TOTAL COST (\$/year):

YARD WASTE:

WHITE GOODS:
The aggregate of all expenditures incurred to manage municipal solid waste, inclusive of general and administrative, planning, capital, collection, processing, transfer and haul, marketing, promotion and education, and disposal costs, less any revenues derived from resource recovery activities.

Vegetative material that is segregated from the MSW stream for separate collection and/or processing, including grass, prunings, plants, and small tree limbs, but excluding tree stumps, land-clearing debris, and other large vegetative matter (see Brush).

That portion of bulky waste which consists of large appliances, such as refrigerators, stoves, washing machines, and dryers. 


\section{Appendix B - Allocation of Gross Costs and Result Tables}

The allocation procedure used to determine the total gross cost incurred for various functions or types of waste is presented in this Appendix. The procedure involved the following steps: (1) classification of each cost by function: (2) determination of costs that are totally or partially "applicable" or "not applicable" to the 10,311 tons of Analyzed MSW; and (3) allocation of the Analyzed MSW costs to the management of two types of wastes: garbage and recycled OCC. Each of these steps is discussed below.

\section{B.1 Step 1: Classification of Costs by Function}

The costs incurred by SSWI, Sevierville, and generators (for bags/cans/containers) were classified into the following functional areas: Collection; Class I Landfill; Class IV Landfill, OCC Recycling (processing) OCC Recycling (collection), Composting Facility, tire shredding, wood grinding, G\&A and Other.

Each of SSWI's line item costs was reviewed by R. W. Beck and allocated to one of the specific functional areas. Because of the level of detail available from SSWI, often it was possible to allocate 100 percent of a specific cost to a given functional area. For example, the cost of the OCC collection truck was provided as a specific line item and thus no allocation between functional areas was required. Other times it was necessary to allocate a given cost between functional areas. For example, SSWI's total cost of diesel fuel was known but how much was used by each landfill or for OCC collection was not known.

The classification of SSWI's costs by function is provided in Tables B-1 and B-2. Table B-3 summarizes the results of Tables B-1 and B-2 and also shows the costs allocated to collection.

\section{B.2 Step 2: Determination of "Applicable" and "Not Applicable" Costs}

Table B-3 shows that $\$ 2,834,230$ of the $\$ 3,928,873$ total gross cost is classified as being "not applicable" to the management of the 10,311 tons of Analyzed MSW.

Each cost was first reviewed to determine whether it could be classified as being either "applicable" or "not applicable" to Analyzed MSW. For example, all costs identified as allocated to the Class IV landfill were determined to be 100 percent "not applicable" because demolition waste is not part of the Analyzed MSW. Costs allocated to tire shredding and to wood waste grinding were also determined to be "not applicable" for the same reason. Tonnage figures were then used to apportion costs between Total MSW and Analyzed MSW. For example, 100 percent of the garbage collection costs shown in Table B-3 are applicable to the management of MSW since the costs reflect Sevierville's cost of collection. Conversely, 100 percent of the composting facility costs shown in Table B-3 are applicable to the management of MSW but only about 20 percent is applicable to the analyzed MSW because Sevierville only accounts for about 20 percent of the total deliveries to the Composting Facility. 


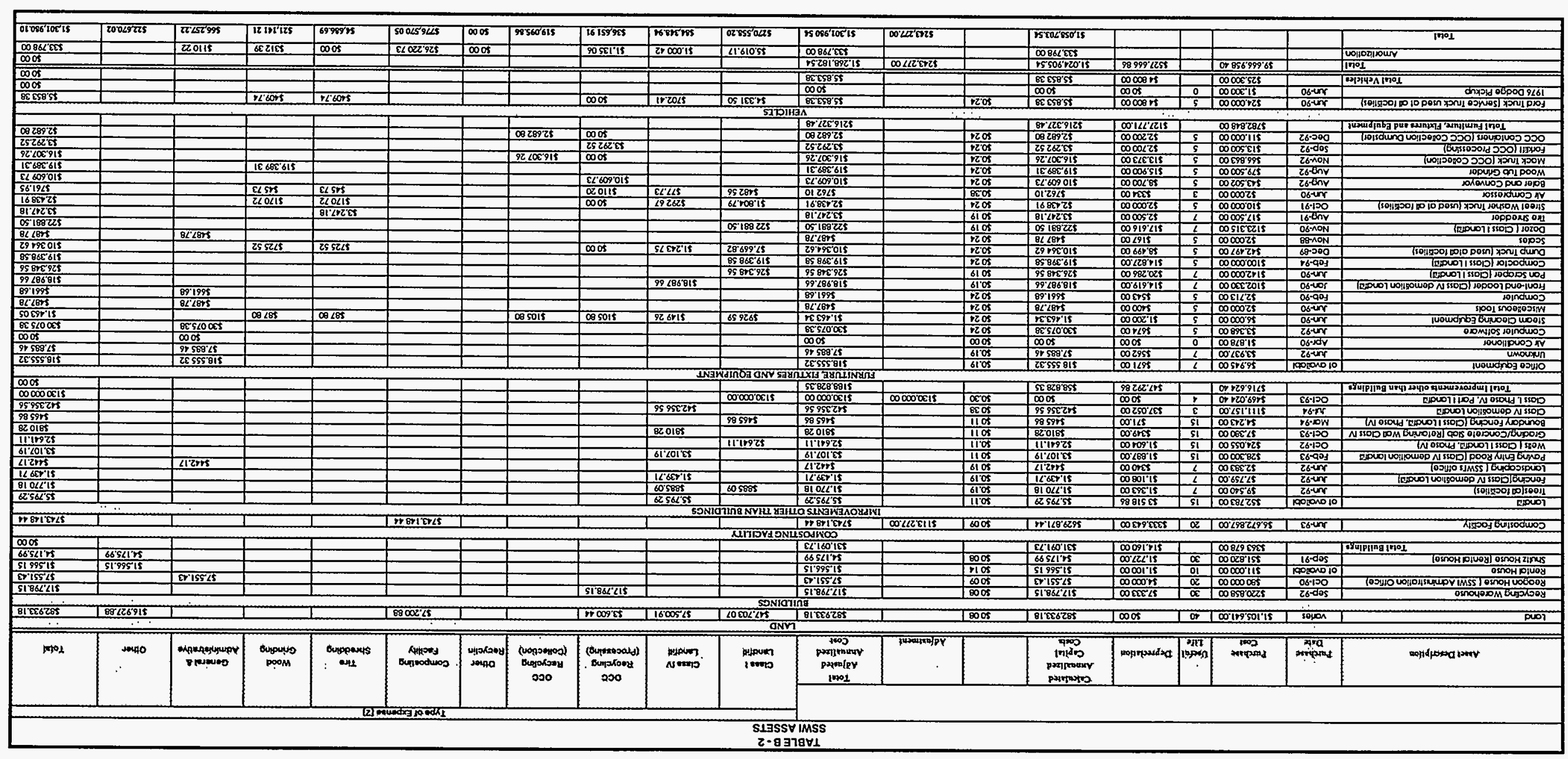


Table B-3. Total Gross Costs of City IMSWMS Allocated by Functional Area (FY 93/94 \$)

\begin{tabular}{|c|c|c|c|c|c|c|c|c|c|c|c|c|}
\hline Description & $\begin{array}{c}\text { Garbage } \\
\text { Collection }\end{array}$ & $\begin{array}{l}\text { Class I } \\
\text { Landfill }\end{array}$ & $\begin{array}{l}\text { Class IV } \\
\text { Landfill }\end{array}$ & $\begin{array}{c}\text { Corrugated } \\
\text { Recycling } \\
\text { Processing }\end{array}$ & $\begin{array}{c}\text { Corrugated } \\
\text { Recycling } \\
\text { Collection }\end{array}$ & $\begin{array}{c}\text { Other } \\
\text { Recycling }\end{array}$ & $\begin{array}{c}\text { Composting } \\
\text { Facility }\end{array}$ & $\begin{array}{c}\text { Tire } \\
\text { Shredding }\end{array}$ & $\begin{array}{l}\text { Wood } \\
\text { Grinding }\end{array}$ & G\&A & Other & Total \\
\hline $\begin{array}{l}\text { SSWI Total } \\
\text { Operating } \\
\text { Expenses }\end{array}$ & 0 & 783,886 & 98,323 & 35,484 & 39,716 & 41,022 & 967,307 & 11,786 & 13,460 & 158,765 & 0 & $2,149,749$ \\
\hline $\begin{array}{l}\text { SSWI Total } \\
\text { Annualized } \\
\text { Capital Costs }\end{array}$ & 0 & 270,558 & 84,349 & 36,652 & 19,096 & 0 & 776,570 & 4,687 & 21,141 & 66,257 & 22,670 & $1,301,980$ \\
\hline $\begin{array}{l}\text { Total Costs - } \\
\text { City } \\
\text { Collection }\end{array}$ & 318,422 & 0 & 0 & 0 & 0 & 0 & 0 & 0 & 0 & 63,684 & 0 & 382,106 \\
\hline $\begin{array}{l}\text { Total Costs - } \\
\text { Bag/Can } \\
\text { Containers } \\
\text { Costs }\end{array}$ & 95,038 & 0 & 0 & 0 & 0 & 0 & 0 & 0 & 0 & 0 & 0 & 95,038 \\
\hline $\begin{array}{l}\text { Total Gross } \\
\text { Cost }\end{array}$ & 413,460 & $1,054,444$ & 182,672 & 72,136 & 58,812 & 41,022 & $1,743,877$ & 16,473 & 34,601 & 288,706 & 22,670 & $3,928,873$ \\
\hline $\begin{array}{l}\text { Percent } \\
\text { "applicable" } \\
\text { to MSW } \\
\text { Analyzed }\end{array}$ & $100 \%$ & $20.14 \%$ & $0 \%$ & $12.7 \%$ & $12.7 \%$ & 0 & $20.14 \%$ & 0 & 0 & $34.97 \%$ & 0 & - \\
\hline $\begin{array}{l}\text { Total } \\
\text { "applicable" } \\
\text { gross cost for } \\
\text { MSW } \\
\text { Analyzed }\end{array}$ & 413,460 & 212,365 & 0 & 9,161 & 7,469 & 0 & 351,217 & 0 & 0 & 100,971 & 0 & $1,094,643$ \\
\hline
\end{tabular}




\section{B.3 Step 3: Allocation of Analyzed MSW Costs by Type of Waste}

The procedure to allocate the $\$ 1,094,643$ total gross cost of managing the 10,311 tons of Analyzed MSW to the cost of managing garbage and OCC required that G\&A expenses be allocated in direct proportion to the allocation of other costs. Table B-4 shows the results of this allocation (excluding collection costs).

Table B-4. Total Gross Costs of City IMSWMS Allocated by Type of Waste (FY 93/94 \$)

\begin{tabular}{lrrr}
\hline \multicolumn{1}{c}{ Type of Waste } & $\begin{array}{c}\text { Total Gross Costs } \\
\text { (without G\&A) }\end{array}$ & Total G\&A & $\begin{array}{c}\text { Total Gross Costs } \\
\text { (with G\&A) }\end{array}$ \\
\hline Garbage & & & \\
Collection & $\$ 413,460$ & $\$ 63,684$ & $\$ 477,144$ \\
Class I Landfill & 212,365 & 13,648 & 226,013 \\
Composting Facility & 351,217 & 22,571 & 373,788 \\
Subtotal & $\$ 977,042$ & $\$ 99,903$ & $\$ 1,076,945$ \\
Corrugated & & $\cdot$ & \\
Processing & $\$ 9,161$ & $\$ 589$ & $\$ 9,750$ \\
Collection & 7,469 & 480 & $\mathbf{7 , 9 4 9}$ \\
Subtotal & 16,630 & 1,069 & 17,699 \\
TOTAL & $\$ 993,672$ & $\$ 100,971$ & $\$ 1,094,643$ \\
\hline
\end{tabular}


. 


\section{Appendix C - Methodology and Data Used to Calculate Total Gross and Net Costs}

The methodology and data used to calculate total gross and net costs for managing MSW (i.e., collecting, processing, composting, and disposing of MSW) disposed by Sevierville are presented in this Appendix. The costs calculated in this Section represent the total costs of the IMSWMS and do not represent the costs attributed to Analyzed MSW. The methodology to calculate total gross and net costs consists of five steps: (1) determining the SSWI's total reported cost; (2) adjusting SSWI's total reported cost, as necessary; (3) estimating Sevierville's municipal collection costs; (4) estimating the costs of plastic bags, trash cans, and containers used to collect garbage; and (5) combining SSWI costs with Sevierville's municipal collection costs and the costs of bags, cans and containers. Each of these steps is described in Sections C.1 through C. 5 below.

\section{C.1 Step 1: Determining SSWI's Total Reported Costs}

SSWI's revenues and expenses for the Fiscal Year ending June 30, 1994 (FY 93/94) are provided in Table C-1. SSWI maintains its books and records on an accrual basis whereby support and revenues are recognized in the accounting period in which they are contributed or earned and expenses in the accounting period in which the liability is incurred. In FY 93/94 SSWI had Operating Revenues of $\$ 2,357,702$, Operating Expenses of $\$ 2,743,945$, and Other Non-Operating Expenses of $\$ 551,959$ for a Net Loss of $\$ 938,202$. Based on the treatment of revenues and expenses in this analysis, (i.e., only recycled material revenues are considered) the reported net loss to the SSWI in FY $93 / 94$ is $\$ 3,284,087$ as shown in Table C-1.

In order to analyze these costs, it was necessary to review the detailed costs that made up these expenses. Detailed cost data was provided to R. W. Beck by SSWI's auditor. Specifically, the auditor's work papers which show expenses by SSWI account number were reviewed. Table C-2 provides a detailed accounting, by account number, of all operating expenses and revenues (before depreciation/amortization) incurred by SSWI in FY 93/94. It also breaks out the SSWI reported costs and revenues used in this study, since some were not necessary to perform the cost analysis. Finally, it indicates adjustments made to the reported costs.

The detailed data were first compared to the final audited data to ensure completeness. The detailed data reconcile exactly with the final audited expenses of SSWI.

SSWI's "Summary of Assets Accumulated Depreciation" provided the derivation of the depreciation/amortization expenses. The Summary of Assets Accumulated Depreciation lists all the assets owned by SSWI (including each asset's purchase price, date of purchase and estimated useful life, and the location of the asset). All assets listed in the fixed asset account are itemized in Table C-3. However, depreciation is not shown for the Class I, Phase VI Landfill for the reasons discussed later in this Appendix.

The purchase price was divided by the estimated useful life of each asset to calculate the depreciation/amortization expense. Assets that were older than their estimated useful lives were assigned no current value. The depreciation/amortization of assets purchased during the fiscal year were pro-rated based on the date of purchase. 
Table C-1. Statement of Revenues and Expenses Year Ending, June 30, 1994

$\begin{array}{ccc} & \begin{array}{c}\text { Analyzed } \\ \text { Reported }\end{array} & \text { Adjusted } \\ \text { As Reported } & \text { Revenues/ } \\ \text { (Expenses) }\end{array}$

\section{OPERATING INCOME:}

Tipping Fees

Bond and Interest Assessments

Rental Income

Other Local Revenue

Total Operating Revenue

\section{OPERATING EXPENSES}

Personnel Costs

Supplies

Maintenance

General Services

Landfill Closure/Post Closure Costs

Other

Recycling Expenses

Composting Expenses

Total Operating Expenses .

Net Operating Income (loss) before

Depreciation and Amortization

Less Depreciation

Less Amortization

Annualized Cost Capital

NET OPERATING INCOME (LOSS)

NON-OPERATING INCOME (EXPENSE):

Investment Income

Bond Interest Expense

Total Non-operating Income

(Expense)

NET INCOME (LOSS)
$\$ 1,440,523$

898,903

5,980

$\underline{12,296}$

$\$ 2,357,702$

$\$ 289,180$

15,161

68,576

159,919

530,740

48,864

41,022

956,354

$\$ 2,109.816$

$\$ 247,886$

615,608

18,521

0

$\$ \$ 386,243)$

$\$ 20,512$

$(572,471)$

$(\$ 551,959)$

$(\$ 938.202)$ $\underline{11,817^{[\mathrm{c}]}}$

$\underline{11,817}$

$\underline{18,117^{[\mathrm{d}]}}$

$\underline{18,117}$

$\$ 289,180 \quad \$ 322,815^{[\mathrm{e}]}$

15,161

15,161

68,576

68,576

159,919

159,919

530,740

$530,740^{\text {เก }}$

48,864

48,864

41,022

41,022

956,354

$\underline{962,654^{[8]}}$

$\$ 2,109,816$

$\$ 2,149,751$

$$
(\$ 2,097,999) \quad(\$ 2,131,634)
$$

615,608

0

18,521

0

$0 \quad 1,301,981^{[\mathrm{h}]}$

$(\$ 2,732,128)$

$\$ 3,433,615)$

$$
\$ 20,512
$$

$(572,471)$

0

$(\$ 551,959)$

$\underline{0}$

$\underline{\$(\$ 3.284,087)}$

$(\$ 3,433,615)$ 
Table C-1. Statement of Revenues and Expenses Year Ending, June 30, 1994

Notes:

[a] Source: SSWI's "Financial Statements, June 30, 1994 and 1993"

(b) Types of reported costs and revenues used in this study are consistent with those used in other case studies performed by CSI.

[c] Other revenues consist of recycling revenues and miscellaneous income. Revenue shown represents recycling revenues only $(\$ 8,974$ for corrugated and $\$ 2,844$ for ferrous recovered at the Class IV landfill).

(4) Adjusted to account for revenues $(\$ 6,300)$ from ferrous sales from the composting facility.

(c) Reflects $\$ 33,635$ adjustment for scale house operator.

in Due to a lack of information, these costs were not calculated using the methodology developed by CSI in the other case studies.

[8] Note [d] adjusted the operating income to account for $\$ 6,300$ in ferrous revenue for ferrous recovered by Bedminster at the compost facility. This adjustment shows the $\$ 6,300$ as an increased cost to SSWI.

It] Reflects substitution of annualized capital costs for depreciation/amortization and net non-operating expenses. Line item is comprised of the following:

Description

Annualized Class I, Phase IVA Capital Costs

Annualized Additional Composting Facility Capital Costs

Annualization of Reported Amortization Items

Annualization of Reported Depreciation Items

Total

Estimate provided by Bedminster (not documented).
Annualized Capital Costs

$\$ 130,000$

$\$ 113,277$ [i]

$\$ 33,798$

$\underline{\$ 1,024,906}$

$\$ 1,301,981$ 


\begin{tabular}{|c|c|c|}
\hline \multicolumn{3}{|c|}{$\begin{array}{l}\text { TABLE C - } 2 \\
\text { SSWI'S OPERATING EXPENSES BEFORE DEPRECIATION AND AMORTIZATION } \\
\text { (YEAR ENDING JUNE 30, 1994) }\end{array}$} \\
\hline $\begin{array}{l}\text { Account } \\
\text { Number }\end{array}$ & Description & $\begin{array}{l}\text { Total } \\
\text { Reported } \\
\text { FY } 93 / 94[1]\end{array}$ \\
\hline \multicolumn{3}{|c|}{$\begin{array}{l}\text { PERSONNEL COSTS } \\
\end{array}$} \\
\hline 6110 & Salaries-Classified & $\$ 197,351$ \\
\hline 6120 & Salaries-Other & $\$ 11,450$ \\
\hline 6130 & Uniforms & $\$ 2,965$ \\
\hline 6140 & Car Allowance & $\$ 4,980$ \\
\hline 6150 & Retirement & $\$ 17,575$ \\
\hline 6160 & Employee Benefits & $\$ 5,541$ \\
\hline 6170 & Payroll Tax Expense & $\$ 16,630$ \\
\hline 6175 & Unemployment Tax Expense & $\$ 1,512$ \\
\hline 6180 & Insurance-Employees & $\$ 27,508$ \\
\hline 6600 & Travel & $\$ 451$ \\
\hline 6610 & Meals & $\$ 603$ \\
\hline 6620 & Lodging & $\$ 1,942$ \\
\hline 6630 & Seminars & $\$ 670$ \\
\hline \multicolumn{2}{|r|}{ Total Personnel Costs } & $\$ 289,179$ \\
\hline \multicolumn{3}{|c|}{ SUPPLIES } \\
\hline 6210 & Office Supplies & $\$ 1.964$ \\
\hline 6220 & Vehicle Operation & $\$ 13,180$ \\
\hline 6230 & Safety Equipment & $\$ 18$ \\
\hline \multicolumn{2}{|r|}{$\begin{array}{r}\text { Total Supplies } \\
\end{array}$} & $\$ 15,161$ \\
\hline \multicolumn{3}{|c|}{ MAINTENANCE } \\
\hline 6330 & Machinery Maintenance & $\$ 19,881$ \\
\hline 6340 & \begin{tabular}{|l|l|} 
Buildings and Grounds Maint. \\
\end{tabular} & $\$ 48,695$ \\
\hline \multicolumn{2}{|r|}{ Total Maintenance } & $\$ 68,576$ \\
\hline \multicolumn{3}{|c|}{ GENERAL SERVICES } \\
\hline 6410 & Telephone & $\$ 2,847$ \\
\hline 6430 & Legal and Professional & $\$ 24,100$ \\
\hline 6450 & Utilities & $\$ 3,443$ \\
\hline 6460 & Equipment lease & $\$ 5,717$ \\
\hline 6470 & Advertising & $\$ 2,178$ \\
\hline 6480 & Insurance-General & $\$ 39,256$ \\
\hline 6490 & Promotion & $\$ 12,200$ \\
\hline 6570 & Engineering Fees-Consulting & $\$ 6,412$ \\
\hline 6571 & Engineering Fees-Well Testing & $\$ 25,783$ \\
\hline 6572 & Engineering Fees-Inspect & $\$ 35,235$ \\
\hline 6573 & Engineering Fees-Other & $\$ 2,750$ \\
\hline \multicolumn{2}{|r|}{ Total General Services } & $\$ 159,919$ \\
\hline \multicolumn{3}{|c|}{ LANDFILL CLOSUREIPOST CLOSURE } \\
\hline 6334 & Landfill Closure/Post Closure & $\$ 530,740$ \\
\hline & Total Landfill Closure Post Closure & $\$ 530,740$ \\
\hline \multicolumn{3}{|c|}{ OTHER } \\
\hline 6200 & Bad Debt & $\$ 2,368$ \\
\hline 6500 & Penalties & $\$ 15,398$ \\
\hline 6535 & State Surcharge & $\$ 16,629$ \\
\hline 6536 & State Annual Maintenance Fee & $\$ 5,532$ \\
\hline 6537 & State financial Assurance & $\$ 7,084$ \\
\hline 6560 & Bank Charges & $\$ 52$ \\
\hline 6590 & Bond Services & $\$ 1,138$ \\
\hline 6650 & Dues and Subscriptions & $\$ 580$ \\
\hline 6660 & Freight & $\$ 86$ \\
\hline \multicolumn{2}{|r|}{$\begin{array}{r}\text { Total Other } \\
\end{array}$} & $\$ 48,866$ \\
\hline \multicolumn{3}{|c|}{ RECYCLING EXPENSES } \\
\hline 6461 & Mefal Bin Rental & $\$ 4,115$ \\
\hline \multirow[t]{2}{*}{6545} & Recycling Contract & $\$ 36,907$ \\
\hline & Total Recycling Expenses & $\$ 41,022$ \\
\hline \multicolumn{3}{|c|}{ BEDMINISTER } \\
\hline 6421 & Bedminister Contract & $\$ 804,643$ \\
\hline 6422 & \begin{tabular}{|l|l|} 
Bedminister-Additional & \\
\end{tabular} & $\$ 151,711$ \\
\hline \multicolumn{2}{|r|}{ Total Bedminister Expenses } & $\$ 956,354$ \\
\hline & TOTAL OPERATING EXPENSES & $\$ 2,109,816$ \\
\hline
\end{tabular}




\begin{tabular}{|c|c|c|c|c|c|}
\hline \multicolumn{6}{|c|}{ TABLE C - 3. SSWI ASSETS } \\
\hline Asset Description & $\begin{array}{c}\text { Purchase } \\
\text { Date } \\
\end{array}$ & $\begin{array}{c}\text { Parchase } \\
\text { Cost }\end{array}$ & $\begin{array}{c}\text { Useful } \\
\text { Lifé } \\
\end{array}$ & Depreciation & $\begin{array}{c}\text { Calculated } \\
\text { Annualized } \\
\text { Capital } \\
\text { Costs } \\
\end{array}$ \\
\hline Land & varies & $\$ 1,105,641.00$ & 40 & $\$ 0.00$ & $\$ 82,933.18$ \\
\hline Recycling Warehouse & Sep-92 & $\$ 220,858.00$ & 30 & $\$ 7,333.00$ & $\$ 17.798 .15$ \\
\hline Reagon House ( SSWI Administration Office) & Oct-90 & $\$ 80,000.00$ & 20 & $\$ 4,000.00$ & $\$ 7,551.43$ \\
\hline Rental House & not available & $\$ 11,000.00$ & 10 & $\$ 1,100.00$ & $\$ 1,566.15$ \\
\hline Shultz House (Rental House) & Sep-91 & $\$ 51,820.00$ & 30 & $\$ 1,727.00$ & $\$ 4,175.99$ \\
\hline Total Buildings & & $\$ 363,678.00$ & & $\$ 14,160.00$ & $\$ 31,091.73$ \\
\hline Composting Facility & Jun-93 & $\$ 6,672,867.00$ & 20 & $\$ 333,643.00$ & $\$ 629,871.44$ \\
\hline Landfill & not available & $\$ 52,783.00$ & 15 & $\$ 3.518 .86$ & $\$ 5.795 .29$ \\
\hline Trees(all facilities) & Jun-92 & $\$ 9,540.00$ & 7 & $\$ 1,363.00$ & $\$ 1,770.18$ \\
\hline Fencing(Class IV demolition Landfill) & Jun-92 & $\$ 7,759.00$ & 7 & $\$ 1.108 .00$ & $\$ 1,439.71$ \\
\hline Landscaping (SSWl's office) & Jun-92 & $\$ 2,383.00$ & 7 & $\$ 340.00$ & $\$ 442.17$ \\
\hline Poving Entry Road (Class IV demoition landfill & Feb-93 & $\$ 28,300.00$ & 15 & $\$ 1,887.00$ & $\$ 3,107.19$ \\
\hline Wells ( Class I Landfill, Phase IV) & Oci-92 & $\$ 24,055.00$ & 15 & $\$ 1,604.00$ & $\$ 2,641.11$ \\
\hline Grading/Concrete Slab (Retaining Wall Class IV & Oct-93 & $\$ 7,380.00$ & 15 & $\$ 349.00$ & $\$ 810.28$ \\
\hline Boundary Fencing (Class I Landfill, Phase IV) & Mar-94 & $\$ 4,243.00$ & 15 & $\$ 71.00$ & $\$ 465.86$ \\
\hline Class IV demolition Landfill & Jul-94 & $\$ 111,157.00$ & 3 & $\$ 37.052 .00$ & $\$ 42,356.56$ \\
\hline Class I, Phase IV, Part ILandfill & Oct-93 & $\$ 469,024.40$ & $\overline{4}$ & $\$ 0.00$ & $\$ 0.00$ \\
\hline Total Improvements other than Buildings & & $\$ 716,624.40$ & & $\$ 47,292.86$ & $\$ 58,828.35$ \\
\hline Office Equipment & not available & $\$ 6,945.00$ & 7 & $\$ 671.00$ & $\$ 18,555.32$ \\
\hline Unknown & Jun-92 & $\$ 3,937.00$ & 7 & $\$ 562.00$ & $\$ 7.885 .46$ \\
\hline Air Conditioner & Apr-90 & $\$ 1.878 .00$ & 0 & $\$ 0.00$ & $\$ 0.00$ \\
\hline Computer Software & Jun-92 & $\$ 3,368.00$ & 5 & $\$ 674.00$ & $\$ 30,075.38$ \\
\hline Steam Cleaning Equipment & Jun-90 & $\$ 6,000.00$ & 5 & $\$ 1,200.00$ & $\$ 1,463.34$ \\
\hline Miscelleous Tools & Jun-90 & $\$ 2,000.00$ & 5 & $\$ 400.00$ & $\$ 487.78$ \\
\hline Computer & Feb-90 & $\$ 2,713.00$ & 5 & $\$ 543.00$ & $\$ 661.68$ \\
\hline Front-end Loader (Class IV demolition Landfill) & Jan-90 & $\$ 102,330.00$ & 7 & $\$ 14,619.00$ & $\$ 18,987.66$ \\
\hline Pan Scraper (Class I Landfill) & Jun-90 & $\$ 142,000.00$ & 7 & $\$ 20,286.00$ & $\$ 26,348.56$ \\
\hline Compactor (Class I Landfill) & Feb-94 & $\$ 100,000.00$ & 5 & $\$ 14,827.00$ & $\$ 19,398.58$ \\
\hline Dump Truck (used atall facilities) & Dec-89 & $\$ 42.497 .00$ & 5 & $\$ 8,499.00$ & $\$ 10.364 .62$ \\
\hline Scales & Nov-88 & $\$ 2,000.00$ & 5 & $\$ 167.00$ & $\$ 487.78$ \\
\hline Dozer (Class I Landfill) & Nov-90 & $\$ 123,315.00$ & 7 & $\$ 17,616.00$ & $\$ 22,881.50$ \\
\hline Tire Shredder & Aug-91 & $\$ 17,500,00$ & 7 & $\$ 2.500 .00$ & $\$ 3.247 .18$ \\
\hline Street Washer T̃uck (used at all facilities) & Oct-91 & $\$ 10.000 .00$ & 5 & $\$ 2,000.00$ & $\$ 2,438.91$ \\
\hline Air Compressor & Jun-90 & $\$ 2,000.00$ & $\overline{3}$ & $\$ 334.00$ & $\$ 762.10$ \\
\hline Baler and Conveyor & Aug-92 & $\$ 43,502.00$ & 5 & $\$ 8,700.00$ & $\$ 10.609 .73$ \\
\hline Wood Tub Grinder & Aug-92 & $\$ 79,500.00$ & 5 & $\$ 15,900.00$ & $\$ 19,389.31$ \\
\hline Mack Truck (OCC Collection) & Nov-92 & $\$ 66.863 .00$ & 5 & $\$ 13,373.00$ & $\$ 16,307.26$ \\
\hline Forkliff (OCC Processing) & Sep-92 & $\$ 13.500 .00$ & 5 & $\$ 2,700.00$ & $\$ 3,292.52$ \\
\hline OCC Containers (OCC Collection Dumpster) & Dec-92 & $\$ 11,000.00$ & 5 & $\$ 2,200.00$ & $\$ 2.682 .80$ \\
\hline Total Furniture, Fixtures and Equipment & & $\$ 782.848 .00$ & & $\$ 127.771 .00$ & $\$ 216,327.48$ \\
\hline Ford Truck (Service Truck used at all facilifies) & Jun-90 & $\$ 24.000 .00$ & 5 & $\$ 4,800.00$ & $\$ 5,853.38$ \\
\hline 1976 Dodge Pickup & Jun-90 & $\$ 1,300.00$ & $\overline{0}$ & $\$ 0.00$ & $\$ 0.00$ \\
\hline Total Vehicles & & $\$ 25,300.00$ & & $\$ 4,800.00$ & $\$ 5,853.38$ \\
\hline Total & & $\$ 9,666,958.40$ & & $\$ 527.666 .86$ & $\$ 1,024,905.54$ \\
\hline Amortization & & & & & $\$ 33.798 .00$ \\
\hline Total & & & & & $\$ 1,058,703.54$ \\
\hline
\end{tabular}




\section{C.2 Step 2: Adjusting SSWI's Reported Total Cost}

For purposes of this analysis, several adjustments were made to SSWI's reported costs. Furthermore, the reported depreciation and amortization expenses and net interest expenses were replaced by a calculated annualized capital cost based on the purchase price, expected useful life of SSWI's capital assets, and an assumed SSWI cost of capital of 7 percent.

\section{C.2.1 Personnel Costs}

SSWI's scalehouse is operated and staffed by a County employee rather than an SSWI employee. Therefore, the reported personnel costs were adjusted by an increase of $\$ 33,635$ ( $\$ 24,000$ base salary plus approximately 40 percent fringe) to account for this additional cost.

\section{C.2.2 Composting Facility}

Bedminster reportedly funded approximately $\$ 1.2$ million in capital costs for modification/changes to the composting facility. According to Bedminster, modifications/changes included the following:

- $\quad$ increased the size of the aeration and compost storage building;

- modified/added to the interior wall structure in the compost storage area;

- modified/added to the original internal odor control system both on and adjacent to the aeration floor;

- $\quad$ modified the conveyor systems;

- $\quad$ added improvements and changes to office space;

- added additional soil filter for odor control and upgraded exhaust fans and piping network; and

- upgraded and modified final compost screening assembly.

Therefore, the capital costs were adjusted by an increase of $\$ 1.2$ million to account for this additional cost. This capital increase is reflected in an increase in the annualized capital costs.

\section{C.2.3}

Revenues from the sale of ferrous recovered from the composting facility accrued to Bedminster and, therefore, are not accounted for in SSWI's financial statements. An adjustment of $\$ 6,300$ was made to account for this revenue.

\section{C.2.4 Calculating the Capital Cost of SSWI's Assets}

SSWI reports capital expenses by depreciating or amortizing capital outlays over the useful life 
of the assets. The procedure used by the SSWI to account for fixed assets is as follows:

- Depreciation on property and equipment is computed using the straight-line method over the estimated useful lives of the assets, which are summarized as follows:

$\begin{array}{ll}\text { Buildings } & 30 \text { years } \\ \text { Furniture and fixtures } & 7 \text { years } \\ \text { Equipment } & 5-7 \text { years } \\ \text { Vehicles } & 3-5 \text { years } \\ \text { Other Improvements } & 15 \text { years }\end{array}$

Furthermore, debt discount, organizational expenses, and bond issue costs are amortized. SSWI also reports the interest expenses incurred on all amounts borrowed to finance capital assets. SSWI does not capitalize construction period interest.

The adjusted cost used in this analysis, as shown in Table C-1, substitutes a Capital Cost for the depreciation. The rationale and procedure used to calculate the Capital Cost are presented in Appendix D. The "Annualized Cost" column in Table C-3 was calculated using this procedure. Table C-4 shows the results of using the rationale and procedures presented in Appendix D to calculate a capital cost as a substitute for amortization.

Table C-4. Annualized Cost of SSWI's Amortization (FY 93/94)

\begin{tabular}{lrcr}
\hline \multicolumn{1}{c}{ Description } & Cost (\$) & Useful Life & Annualized Cost (\$) \\
\hline Organizational Expense & 4,387 & 19 & $\$ 424$ \\
Bond Issue Costs & 232,510 & 19 & 22,496 \\
Bond Discount & 112,430 & 19 & 10,878 \\
TOTAL & $\mathbf{3 4 9 , 3 2 7}$ & & $\mathbf{\$ 3 3 , 7 9 8}$ \\
\hline
\end{tabular}

\section{C.2.5 Capital Cost Calculation of Landfill}

The preceding subsection addressed the methodology used to calculate the capital costs of SSWI's assets. However, the Class I landfill was excluded from the preceding analysis. The Class I landfill was excluded because the capital cost of a landfill in any year is correlated to the level of consumption of landfill capacity rather than the age of the landfill. The consumption approach specifically takes into account the various consumption rates of garbage and compost residue. The depreciation/amortization approach does not take into account these variables. It assumes a linear or uniform annual consumption rate regardless of the amount or types of wastes disposed of in the landfill. To estimate the capital cost of the Class I landfill, the landfill cost was divided by its volumetric capacity, to obtain a cost per cubic yard of capacity. This value was then converted to cost per ton of capacity using an assumed in-place density and then multiplied by the capacity (i.e., tons) actually consumed in FY 93/94 to obtain the annual capital cost of the landfill. 
The cost of the Phase IVA landfill Parts 1 and 2 is estimated at approximately $\$ 930,000$ in FY 93/94 dollars. The design capacity of Parts 1 and 2 is approximately 380,000 cubic yards, according to SSWI's landfill engineer. The landfill engineer indicated that the assumed in-place density is 750 pounds per cubic yard. Therefore, the annualized capital cost is estimated to be $\$ 6.54$ per ton. It should be noted that this excludes the costs of items such as land, fencing, wells and mobile equipment. The capital cost of these items were accounted for in Table C-3 using the methodology explained in Appendix D. As noted previously in this report, during FY 93/94, SSWI actually operated two Class I landfills; the old "extension" and the new Phase IV. Insufficient information was available on which to evaluate a cost of the old "extension" landfill. Therefore, the Class I landfill capital cost will be applied to all the Class I tonnage landfilled in FY $93 / 94$ at the $\$ 6.54$ per ton cost of the Phase IV landfill. The FY 93/94 annualized landfill capital cost is estimated at $\$ 130,000(19,574$ tons $\times \$ 6.54 /$ ton $)$.

Due to a lack of data, the costs of the Class IV demolition landfill could not be evaluated using this consumption rate approach. Therefore, the Class IV landfill was accounted for in Table C-3.

\section{C.3 Step 3: Estimating City of Sevierville's Municipal Collection Service Costs}

Sevierville's Department of Sanitation is responsible for the day-to-day collection of residential and commercial garbage within Sevierville. However, many services such as vehicle and equipment maintenance and other general and administrative (G\&A) services such as support services are provided by ther City departments. Since garbage collection in Sevierville is paid for from general revenues and is not treated as an enterprise system, a consolidated accounting of the costs of collection is not available. Instead, R. W. Beck determined the total cost of collection by compiling information provided by Sevierville and making estimates and assumptions when needed.

Table C-5 shows an itemized breakdown of the actual FY 93/94 expenditures for the Sanitation Department. Table C-5 shows that Sevierville's payment to SSWI is included in the total expenditure. R. W. Beck deducted SSWI's payment since this has already been accounted for in the cost analysis of SSWI. After deduction of the SSWI payment, the total expenditure was $\$ 229,147$. Based on discussions with Sevierville staff, ten percent of the actual expenditures incurred by Sevierville garage were allocated to the Sanitation Department which adds an additional cost of $\$ 7,435$.

The Sanitation Department fund does not include the cost of capitalized assets. Therefore, a list of the collection vehicles used by Sevierville was obtained from Sevierville. This list included original purchase price and date of purchase. An annualized capital cost expense was determined for the vehicles using the procedures described in Appendix D. The calculation of the annual capital cost assumed a 7-percent cost of capital and a useful life of five years. Table C-6 shows the vehicles and the associated annualized cost of $\$ 81,839$.

R. W. Beck assumed that G\&A expenses would be approximately 20 percent of the total costs based on professional judgement and a review of Sevierville's total budget in relation to the cost of collection.

Table C-7 shows the estimated total Sevierville cost of collection in FY 93/94. 
Table C-5. City of Sevierville FY 93/94 (Fund: 122 - Sanitation)

\begin{tabular}{llr}
\hline $\begin{array}{c}\text { Acct No. } \\
43200-\end{array}$ & & Account Name \\
\hline 111 & Salaries & Cost \\
112 & Overtime & 2137,022 \\
134 & Christmas Bonus & 2,980 \\
141 & OASI (Taxes) & 1,516 \\
142 & Medical Insurance & 10,507 \\
143 & Retirement & 30,887 \\
148 & Disability and Life & 9,564 \\
251 & Medical Services (Hep B Vaccine) & 1,662 \\
261 & Repairs and Maintenance (Contract Services) & 170 \\
295 & Landfill Services (Payment to SSWI) & 1,029 \\
322 & Chemicals (Soap for Washing Vehicles) & 410,411 \\
326 & Uniforms & 1,538 \\
331 & Gas and Oil & 2,323 \\
332 & Parts (Supplies in-house) & 13,361 \\
333 & Repair and Maint. & 5,793 \\
334 & Tires & 3,401 \\
& Total & $\mathbf{7 , 4 0 4}$ \\
\hline & Total less SSWI Payment & $\$ 639,559$ \\
& & $\$ 229,147$ \\
\hline
\end{tabular}

Table C-6. Annualized Capital Costs of City Vehicles

\begin{tabular}{cccc}
\hline $\begin{array}{c}\text { Date of } \\
\text { Purchase }\end{array}$ & $\begin{array}{c}\text { Purchase } \\
\text { Price (\$) }\end{array}$ & $\begin{array}{c}\text { Vehicles Useful Life } \\
\text { (Years) }\end{array}$ & $\begin{array}{c}\text { Annualized Capital Cost } \\
\text { (FY 93/94 S) }\end{array}$ \\
\hline 1983 & $\$ 45,560$ & 5 & 0 \\
1987 & 91,544 & 5 & 0 \\
1988 & 57,384 & 5 & 13,996 \\
1989 & 105,950 & 5 & 25,841 \\
1991 & 63,847 & 5 & 15,572 \\
1992 & 108,375 & 5 & 26,433 \\
& Total & & 81,839 \\
\hline
\end{tabular}


Table C-7. Total City Cost of Collection (FY 93/94\$)

\begin{tabular}{lr}
\hline Sanitation Fund (less payment to SSWT) & $\$ 229,147$ \\
City Garage & 7,435 \\
Vehicle Annualized Capital Costs & 81,839 \\
G\&A & 63,684 \\
TOTAL & $\$ 382,106$ \\
\hline
\end{tabular}

\section{C.4 Step 4: Estimating Costs of Bags, Cans, and Containers}

In addition to the expenses incurred by Sevierville and SSWI, individuals and businesses incur the costs of plastic bags, garbage cans, and containers used in garbage collection. Since a dropoff program is used in Sevierville for recyclables collection, it is reasonable to assume that containment costs to the residents is minimal. However, SSWI provides for the containers used in the commercial Corrugated Collection Program and this cost was reflected in the analysis of SSWI's costs. Therefore, the cost of using bags, cans, and containers must be included in the cost of managing garbage. Using the methodology developed for the previous case studies, the cost of containment for garbage can be determined as follows.

The estimated costs of bags, cans, and containers is determined by multiplying the cost per bag, can, or container by the number of each used. Plastic bags are not reusable and are, therefore, consumed when the garbage is picked up. On the other hand, trash cans and containers are capital goods. Furthermore, many people used both plastic bags and either cans or containers, i.e. the plastic bag is used in the garbage can and plastic bags of garbage are thrown into the garbage containers at businesses. To estimate these costs, the following assumptions were used, consistent with previous studies:

- For residential and commercial curbside garbage collection, 65 percent of all customers use plastic bags and 70 percent of customers use garbage cans.

- For commercial dumpster collection, 80 percent of all customers use bags.

- A 30-gallon plastic bag and 30-gallon garbage can hold approximately 0.149 cubic yards or 0.011 tons of garbage.

- The average cost of a 30 -gallon plastic bag is about $\$ 0.13$.

- The average cost of a 30-gallon garbage can is $\$ 20$, and the average cost of a commercial dumpster is $\$ 500$; both have a useful life of 10 years.

- The cost of capital is 7 percent.

Using the above assumptions, the average cost of using plastic bags is about $\$ 11.73$ per ton. The 
annualized capital cost of a garbage can that is used once a week is $\$ 4.98$. The annualized capital cost of containers used twice a week is $\$ 1.14$.

An estimated 1,860 tons of residential garbage was collected from residences in FY 93/94. The estimated cost of bags and cans for these residences is:

$$
[(0.65)(11.73)+(0.70)(4.98)](1,860)=\$ 20,666
$$

An estimated 8,175 tons of garbage was collected from commercial dumpsters accounts in FY 93/94. The estimated costs of bags and containers for these customers is

$$
[(0.65)(11.73)+(1)(1.14)](8,175)=\$ 71,650
$$

An estimated 245 tons of garbage was collected from commercial curbside accounts in FY 93/94. The estimated cost of bags and cans for these customers is:

$$
[(0.65)(11.73)+(.7)(4.98)](245)=\$ 2,722
$$

The sum of these costs is the $\$ 95,038$ estimated cost of bags, cans and containers for the collection of garbage in Sevierville .

\section{C.5 Combining SSWI and City of Sevierville Municipal Collection Costs}

The total gross and net cost of Sevierville's IMSWMS is shown in Table C-8. These are the costs used in Appendix B.

Table C-8. Total Gross and Net Costs of IMSWMS (FY 93/94\$)

\begin{tabular}{lrr}
\hline & \multicolumn{1}{c}{ Gross } & \multicolumn{1}{c}{ Net } \\
\hline SSWI & $\$ 3,451,732$ & $\$ 3,433,615$ \\
City Municipal Collection & 382,106 & 382,106 \\
Bag/Can/Container Costs & 95,038 & 95,038 \\
TOTAL & $\$ 4,075,227$ & $\$ 4,057,110$ \\
\hline
\end{tabular}





\section{Appendix D - Capital Cost Calculation'}

A capital expense is the purchase of an asset or service with a useful life of greater that one year. Accountants report capital expenses as capital outlays, i.e., the actual payment made during the year, or as depreciated/amortized expenses. One depreciation method is straight line depreciation, wherein the capital outlay is divided by the useful life of the asset.

Capital assets may be purchased entirely with cash, financed over time using borrowed funds, or a combination of the two. If totally or partially financed, interest payments on borrowed funds are reported by accountants as interest expenses.

Following these accounting practices the cost of a capital asset in a given reporting period (e.g., fiscal year) is reported as either the capital outlay incurred, or the depreciation/amortization expense incurred in the reporting period, plus interest paid, if any, on borrowed funds to finance the capital asset. Some financial reports, such as a cash flow analysis, also report the actual debt service, i.e., principal plus interest payments, on borrowed funds.

Although these approaches are appropriate for generating financial statements of non-profit organizations, none is an appropriate measure of the economic capital costs of the asset. The reporting of capital outlays does not recognize that a capital asset will be used over two or more years and, therefore, its costs should be spread over the assets useful life. The depreciation/amortization approach does not adequately distinguish between the same asset purchased with cash or with borrowed funds. Because loan repayment and debt service payments, and in particular the interest portion of such payments, can vary significantly from year to year based solely on the means of borrowing funds and not the use of the asset, these expenses are not an appropriate measure of the capital cost of the asset.

The approach used in the report was to calculate capital costs is to "annualize" or "capitalize" capital outlays over the useful life of the asset using a cost of

capital of 7 percent. ${ }^{2}$ Generally, the cost of capital reflects the rate of return expected on invested funds.

Using this approach the capital cost of an asset is independent of the method used to pay for the asset, and has the same annual value over the useful life of the asset.

To illustrate the method used to calculate capital costs and compare it to the other ways of reporting capital expenses, consider a transfer tractor and trailer with a 5 year useful life and a purchase price of $\$ 105,000$.

To estimate the annual capital cost the purchase price (i.e., capital outlay) of $\$ 105,000$ is multiplied by the following capitalization factor:

1 Methodology and test developed by CSI Resource Systems, Incorporated.

${ }^{2}$ The cost of capital is related to the rates of return that can be earned on invested funds and the rates of interest that must be paid on borrowed funds. As the economy changes and interest rates increase or decrease, the cost of capital may also change over time. The 7-percent cost of capital is about the mid-point of cost of capital often used for public entities. 


\section{$r$ \\ $\overline{1-\left[1 /(1+r)^{n}\right]}$}

where " $r$ " is the cost of capital, or .07 in this analysis, and " $n$ " is the useful life of the asset in years.

Substituting .07 for " $\mathrm{r}$ " and 5 for " $\mathrm{n}$ " in the above equation results in a capitalization factor of:

$$
0.2539=\frac{.07}{1-\left[1 /(1.07)^{5}\right]}
$$

Multiplying $\$ 105,000$ by this capitalization factor results in an annual capital cost of $\$ 25,610$. Capitalization factors for various costs of capital and useful lives of assets are provided in Table D.1.

Table D.2 shows the difference between the capital cost calculated above for this tractor/trailer over its 5 year useful life and the capital expenses reported using various accounting procedures. This table clearly shows that the differences among these reporting procedures vary significantly. Also note that the capital cost as calculated above is identical to the a loan repayment or debt service schedule on a 7 percent loan with a constant annual repayment schedule as shown in Case 7. 
TABLE D.1: CAPITALIZATION FACTORS

\begin{tabular}{rrrrrrr}
\hline \multirow{7}{*}{$\begin{array}{c}\text { NUMBER } \\
\text { YEARS }\end{array}$} & $5 \%$ & $6 \%$ & $7 \%$ & $8 \%$ & $9 \%$ & $10 \%$ \\
\cline { 2 - 7 } & & & & & & \\
\hline 2 & 0.5378 & 0.5454 & 0.5531 & 0.5608 & 0.5685 & 0.5762 \\
3 & 0.3672 & 0.3741 & 0.3811 & 0.3880 & 0.3951 & 0.4021 \\
4 & 0.2820 & 0.2886 & 0.2952 & 0.3019 & 0.3087 & 0.3155 \\
5 & 0.2310 & 0.2374 & 0.2439 & 0.2505 & 0.2571 & 0.2638 \\
10 & 0.1295 & 0.1359 & 0.1424 & 0.1490 & 0.1558 & 0.1627 \\
15 & 0.0963 & 0.1030 & 0.1098 & 0.1168 & 0.1241 & 0.1315 \\
20 & 0.0802 & 0.0872 & 0.0944 & 0.1019 & 0.1095 & 0.1175 \\
30 & 0.0651 & 0.0726 & 0.0806 & 0.0888 & 0.0973 & 0.1061 \\
40 & 0.0583 & 0.0665 & 0.0750 & 0.0839 & 0.0930 & 0.1023 \\
50 & 0.0548 & 0.0634 & 0.0725 & 0.0817 & 0.0912 & 0.1009 \\
\hline
\end{tabular}


TABLE D.2: COMPARISON OF CAPITAL COSTS AND OTHER ACCOUNTING METHODS PURCHASE OF TRACTOR/TRAILER WITH 5-YEAR USEFUL LIFE FOR $\$ 105,000$

\begin{tabular}{|c|c|c|c|c|c|c|c|c|c|}
\hline YEAR & $\begin{array}{l}\text { CAPITAL } \\
\text { COST }\end{array}$ & CASE 1 & CASE 2 & CASE 3 & CASE 4 & CASE 5 & CASE 6 & CASE 7 & CASE 8 \\
\hline 1 & 25,609 & 105,000 & 112,350 & 112,350 & 21,000 & 28,350 & 28,350 & 25,609 & 28,350 \\
\hline 2 & 25,609 & 0 & 6,072 & 5,880 & 21,000 & 27,072 & 26,880 & 25,609 & 26,880 \\
\hline 3 & 25,609 & 0 & 4,704 & 4,410 & 21,000 & 25,704 & 25,410 & 25,609 & 25,410 \\
\hline 4 & 25,609 & 0 & 3,241 & 2,940 & 21,000 & 24,241 & 23,940 & 25,609 & 23,940 \\
\hline 5 & 25,609 & 0 & 1,675 & 1,470 & 21,000 & 22,675 & 22,470 & 25,609 & 22,470 \\
\hline
\end{tabular}

DEFINITION OF CASES:

CASE 1: Capital Outlay reporting. Purchased with cash.

CASE 2: Capital Outlay reporting. Financed with borrowed funds. Interest $7 \%$. Constant annual payments

CASE 3: Capital Outlay reporting. Financed with borrowed funds. Interest rate of $7 \%$. Constant principal payment, interest paid on unpaid balance.

CASE 4: Straight line depreciation/amortization reporting. Purchased with cash.

CASE 5: Straight line depreciation/amortization reporting. Financed with borrowed funds. Interest rate of $7 \%$. Constant annual payments.

CASE 6: Straight line depreciation/amortization reporting. Financed with borrowed funds. Interest rate of $7 \%$. Constant principal payment

CASE 7: Debt Service reporting. Financed with borrowed funds. Interest rate of $7 \%$. Constant annual payments

CASE 8: Debt Service reporting. Financed with borrowed funds. Interest rate of $7 \%$. Constant annual principal payments. 


\section{REPORT DOCUMENTATION PAGE}

Public reporting burden for this collection of information is estimated to average 1 hour per response, including the time for reviewing instructions, searching existing data sources, gathering and maintaining the data needed, and completing and reviewing the collection of information. Send comments regarding this burden estimate or any other aspect of this collection of information, including suggestions for reducing this burden, to Washington Headquarters Services, Directorate for Information Operations and Reports, 1215 Jefferson Davis Highway, Suite 1204, Arlington, VA 22202-4302, and to the Office of Management and Budget, Paperwork Reduction Project (07040188), Washington, DC 20503.

\begin{tabular}{|l|c|c|}
$\begin{array}{l}\text { 1. AGENCY USE ONLY (Leave } \\
\text { blank) }\end{array}$ & $\begin{array}{c}\text { 2. REPORT DATE } \\
\text { September } 1995\end{array}$ & $\begin{array}{c}\text { 3. REPORT TYPE AND DATE } \\
\text { Final Subcontract Report }\end{array}$ \\
\hline
\end{tabular}

4. TITLE AND SUBTITLE

Integrated Solid Waste Management of Sevierville, Tennessee

5. FUNDING NUMBERS

6. AUTHOR(S)

*

(C) AAL-3-13185-01

(TA) WM51.1010

\begin{tabular}{|l|} 
7. PERFORMING ORGANIZATION NAME(S) AND ADDRESS(ES) \\
\hline
\end{tabular}

The Solid Waste Association of North America

8. PERFORMING

ORGANIZATION

REPORT NUMBER

DE95009249

9. SPONSORING/MONITORING AGENCY NAME(S) AND ADDRESS(ES)

National Renewable Energy Laboratory

1617 Cole Boulevard

Golden, CO 80401-3393

10.

SPONSORINGMONITORING

AGENCY REPORT

NUMBER

NREL/TP-430-8136

\section{SUPPLEMENTARY NOTES}

\section{2a. DISTRIBUTION/AVAILABILITY STATEMENT}

National Technical Information Service

U.S. Department of Commerce

5285 Port Royal Road

Springfield, VA 22161 12b. DISTRIBUTION CODE

UC-1414

\section{ABSTRACT (Maximum 200 words)}

One of a series of six reports that describes in detail the solid waste management of Sevierville, Tennessee; the energy consumed to operate the system, and the environmental performance requirements for each of the system's waste-processing and disposal facilities. The report is in two parts, a condensed version and an in-depth report with added detail.

\section{SUBJECT TERMS}

Municipal solid waste management; energy consumption; Sevierville, Tennessee; cost analysis; recycling; waste-to-energy.

15. NUMBER OF PAGES

200

16. PRICE CODE

20. LIMITATION OF

ABSTRACT
17. SECURITY

CLASSIFICATION

OF REPORT

Unclassified
18. SECURITY

CLASSIFICATION

OF THIS PAGE
19. SECURITY

CLASSIFICATION

OF ABSTRACT 
